\title{
Ottoman Archival Documents on the Shrines of Karbala, Najaf, and the Hejaz (166os-172os): Endowment Wars, the Spoils System, and Iranian Pilgrims
}

\author{
Selim Güngörürler \\ FWF Fellow, Institute of Iranian Studies, Austrian Academy of Sciences \\ Selim.Guengoeruerler@oeaw.ac.at
}

\begin{abstract}
This study introduces and publishes an array of Ottoman archival documents on the shrines of Ahl al-Bayt imams in Iraq, the endowments dedicated to these shrines, and the Shiite-Iranian pilgrims visiting these sites as well as the Kaaba and the shrine of Muhammad in the Hejaz. Focusing on the later seventeenth and the early eighteenth centuries, it discusses the political-economic function of Islamic endowments, interconfessional contacts resulting from pilgrimage by Shiites in Sunni territory, and the potential use of Ottoman archives to enrich our knowledge on trans-Ottoman themes.
\end{abstract}

\section{Keywords}

Atabat - Hajj - Shiite-Sunni contacts - Ottoman-Safavid relations - waqf - Ottoman archives

\section{Introduction}

In the present paper I translate, transcribe, and reproduce a set of Ottoman archival documents on the Imamic shrines of Karbala and Najaf, their endowments, the rivalry between factions at the local, regional, and imperial level to control their funds as well as tenures, their visitation by Shiite Iranians, and likewise the pilgrimage of Shiite Iranians to Mecca and Medina. These writs span the time from the mid-seventeenth century up to the early eighteenth 
century, while further documents that come from the same archives but are not chosen for publication are also referenced in this study. The introduction, especially the observations and commentary that follow the background setting, thematically prunes out and refines the raw information found in these writs. The contrast between the thematic makeup of the introduction and the blocks of data found in the documents highlights how one can draw out from such sources a set of information that those who created and kept these writs did not have in focus. Therefore this introduction, notwithstanding its length, is not a conventional article laying out, unfolding, and wrapping up an argument, but rather a purposeful extract of the documents, and a case study more generally on the use of Ottoman archival material for new explorations in early modern history.

Taken together, these sources shed new light on how these shrines brought together individuals as well as institutions from the Iraqi countryside, from the provincial governorate at Baghdad, and from the imperial court in a contest for the control of the wealth redistributed through the endowments of these shrines in the form of sinecures. They likewise help us understand in which way the Ottomans oversaw Shiite-Iranian pilgrimage in the Empire, how the Safavid government regarded the shuttling of its subjects between Iran and Sunni Ottoman lands, what these visitations meant for the shrine towns, which regulations thereon came into being between the state and its appointees in provinces, to what extent these subject matters made it into the agenda of political diplomacy, and whether a 'confessionalization' can be seen in these contacts between Shiites and Sunnis.

When taken as a whole, these documents allow us to draw a number of significant inferences. The struggle for the control of Islamic endowments in general lay at the heart of these institutions insomuch that even the endowments for the shrines of the Imams of the House of Muhammad were entangled in the game of appropriating public wealth through lawful means for patrons to fund their clients in political rivalries between factions. These patron-client networks were built-in parts of the Ottoman Empire though, notwithstanding the clash between them, and as they were made up of state bureaus, their branches, and institutional communities, up the ladder each faction ended in one and the same imperial government. The Ottoman state had incorporated the shrine complexes of Ali b. Abi-Talib in Najaf and Husayn b. Ali in Karbala and their income streams into its imperial system as the Endowments of the Two Illustrious Martyria (اوقاف مشهدين شريفين). These shrines thus became embedded in a network of persons and writs that spanned the axes from Iraq to Hungary and from Anatolia to Arabia, and even stretched out to Egypt and across the border to Iran. 
These shrines were popular pilgrimage sites for Muslims from home and abroad, including Shiites from Iran. The documents verify the argument-or rather the guess - advanced by historians that with the peace of 1639 there arose in Ottoman-Safavid relations a kind of territorialization in religious claims laid by these states, ${ }^{1}$ though this otherwise-ungrounded assumption comes out right only coincidentally. From the 1640s onward, in Ottoman-Safavid diplomacy and within the Ottoman government in its dealings with Shiite visitors from Iran, the talk of Shiism and Sunnism were neither brought up officially nor hinted at, even if the actors may have been mindful of sectarian disagreements and even when there were local outbreaks of sectarian strife. Besides, Ottoman Sunnism itself revered the saints over whose graves the aforesaid shrines had been raised-Imams of the House of Prophet Muhammad, above all Ali and Husayn — not for the sake of formality but out of its own devotion, though in a way other than that in Shiism. In Mecca, Medina, and on the road to the Hejaz, the Ottoman state ordered its appointees to treat the Iranian, that is Shiite, pilgrims the same as other Muslims, i.e. Sunnis. Although the Shiite-Sunni sectarian strife was by no means settled, Ottoman politicians shut their eyes to it in their contacts with Iran, and went so far as to end the role played by the Empire's Sunni 'ulama' in diplomatic dealings with the Safavids. The parties did not confessionalize their dialogue about the Shiite pilgrims coming from Iran into the Empire.

For administrative processes within the Empire such as petitioning, opening lawsuits, appealing to dignitaries, and enforcing formerly issued writs in such processes, the Ottoman state dealt with Iranian pilgrims as if they were its own subjects. Although it did not identify them as subjects of the Empire, it did not deem them as full aliens either. Iranian pilgrims in the Ottoman Empire were treated as non-subjects to whom the law of subjecthood applied, outside of taxing purposes. These Shiite Iranian pilgrims and the Safavid shahs' gifts to shrines in Ottoman territory became topics of diplomacy only when the two states were cooperating against rebels in the field or holding talks on exceptional Safavid requests for Ottoman permission on sensitive projects. Besides, the inflow of wealth from Iran to the local economies of shrine towns within the Empire was remarkable enough for Ottoman officials to be mindful of the rises and drops in it.

1 As put forward, among others, by R.K. Ramazani in his The Foreign Policy of Iran 1500-1941 (Charlottesville: University Press of Virginia, 1966): 19. 


\subsection{Background}

The "Sublime Thresholds" (عتبات عاليات), i.e. the shrines of Imams from the House of Muhammad in Iraq (Ali b. Abi-Talib in Najaf, Husayn b. Ali in Karbala, Musa al-Kazim b. Jafar as well as Muhammad al-Javad b. Ali in Baghdad's Kazimiya, and Ali al-Hadi b. Muhammad as well as Hasan al-Askari b. Ali in Samarra) had long been focal points of Islamic ideology, sources of legitimacy, centers of wealth redistribution, and sites of pilgrimage. Abbasid caliphs were the first to construct the buildings that would grow into the later shrine complexes, especially of Ali in Najaf and Husayn in Karbala, and Buyid rulers furthered these early works. Then, the Seljukid and the Ilkhanid monarchies made additions, followed by a rebuilding by Tamerlane. The Safavids and especially the Ottoman state also contributed greatly in infrastructure and renovations. The religious devotion towards, ideological importance of, and the material investment in these shrines had a supra-sectarian character, drawing in the Shiites and the Sunnis alike, notwithstanding the difference between the Shiite and the Sunni understandings on the divinity of the Imams. Therefore, Safavid shah Ismail I's canal digging project, for example, was picked up and expanded by the Ottoman emperors Suleiman I, Selim II, and Murad III in the sixteenth century. Likewise, in the seventeenth century, the additions made by the Safavid shahs Abbas I and Safi I were furthered under the Ottomans Murad IV, Mehmed IV, and later Ahmad III. ${ }^{2}$

The Ottoman state took seriously the safety of Ali's and Husayn's shrines, and of the pilgrims visiting them. Thus when, for example, a Bedouin uprising befell southern Iraq, it sent separate troops led by a governor from Anatolia to guard Najaf and Karbala only, besides the imperial army already fielded under the command of the governor-general. ${ }^{3}$ Misdeeds must have happened notwithstanding any policy or measures. But the few occasions when a source left behind a non-native, in disagreement with the more direct and betterinformed domestic sources available, claims that the Ottomans oppressed

2 Wameedh Sarhan al-Rubaye, "Bağdat Vakıfları (1534-1830)" (Phd Dissertation, Gazi Üniversitesi, 2020): 98-99, 109; Türkiye Diyânet Vakfi İslam Ansiklopedisi: "Atebât" by Avli İlhan in vol. 4 (1991): 49-50; "Kerbelâ" by Mustafa Öz in vol. 25 (2002): 271-272; "Meşhed-i Ali" by Abdüsselam Uluçam in vol. 29 (2004): 365-366; "Necef" by Mustafa Öz in vol. 32 (2006): 486-487.

3 Anonim Osmanlı Tarihi (1099-1116 / 1688-1704), ed. Abdülkadir Özcan (Ankara: Türk Tarih Kurumu Basımevi, 200o): 191; Silâhdâr Fındıklılı Mehmed Ağa, Nusretname, ed. Mehmet Topal (Ankara: Türkiye Bilimler Akademisi, 2018): 684, 812; Defterdar Sarı Mehmed Paşa, Zübde-i Vekayiât, ed. Abdülkadir Özcan (Ankara: Türk Tarih Kurumu Basımevi, 1995): 740; C. Melville, "Shah 'Abbas and the Pilgrimage to Mashhad." In Safavid Persia: The History of Politics of an Islamic Society, ed. Charles Melville (London: I.B. Tauris, 1996): 216. 
Iraq's Shiite dwellers or pilgrims coming from Iran, ${ }^{4}$ it should be taken with a grain of salt. Because in these cases, the wrongdoing "Turks" could indeed be some Bedouin tribes rising up against the Empire or against an official acting contrary to the center's behest. Either way, the state recompensed the wronged and retaliated against the wrongdoer in the wake of such cases. ${ }^{5}$ Documents published and cited in the present paper further uphold this reading.

Donations by rulers and dignitaries to the shrines were mostly made from their tax-sourced wealth. The ground on which endowed buildings were constructed was also taken out of the public land. Especially during the period under discussion here, the villages, fees, tolls, businesses, and suchlike, which were endowed as income for the shrines and used among other purposes for assigning the non-service stipends to favored proteges, were likewise written off from the treasury and taxes of the state. Thus, for targeted payments, money was irrevocably allocated from public property and treasury income, instead of being endowed from individuals' private wealth. Islamic law came to acknowlوقف) edge this kind of write-off as valid, naming them unauthentic endowment (غير صحيح . So, sinecures dealt out through political favoritism were sourced from the wealth that the Empire as a whole-including both the ruling and the ruled - was to benefit from, rather than out of the pockets of those who made and received these allotments. Already by the mid-sixteenth century this phenomenon had become so widespread in the Empire's Balkan-Anatolian core and its Arab lands that the monarch and the jurists had to tackle the losses to the treasury resulting from these permanent write-offs. Scarcely upheld was the principle of allotting such unauthentic endowments towards expenditures that otherwise had to be undertaken by the state treasury. Most of the public wealth that was endowed thus, as if it were private property, went into the pockets of those living off patronage networks. ${ }^{6}$ The documents examined in the present paper lay bare how the political power drew on endowments to give away state holdings, outwardly in the name of pious charity but indeed for funding gratuitous nepotism - a lawful means of misappropriation that has found application in Muslim polities since the Middle Ages.

In Mecca and Medina, the Ottoman monarch was responsible for ensuring the unhindered fulfillment of the hajj and for keeping the highways on

4 As reported in R. Matthee, "Between Arabs, Turks and Iranians: The Town of Basra, 16oo1700." Bulletin of School of Oriental and African Studies 69/1 (2006): 70-71.

5 Silahdar Fındıklılı Mehmed Ağa, Zeyl-i Fezleke, ed. Nazire Karaçay Türkal (Phd Dissertation, Marmara Üniversitesi, 2002): 1527, 1570-1573; Sarı Mehmed, Zübde-i Vekayiât: 478.

6 A. Akgündüz, İslam Hukukunda ve Osmanlı Tatbikatında Vakıf Müessesesi (Ankara: Türk Tarih Kurumu Basımevi, 1988): 423-457. 
which the pilgrims travelled to the Hejaz open and safe. The Ottoman state owed this to all Muslims notwithstanding what confession they believed in and where they came from. This obligation of course carried a danger, in that an unfriendly foreign polity could easily send in a spy under the guise of a pilgrim. The Empire thus had to balance its obligation on the one hand to enable pilgrimage by foreign subjects, including Shiite Iranians, and on the other to monitor and regulate their activities. ${ }^{7}$ The wardship of Mecca and Medina had much weight in the make-up of Ottoman legitimacy in the imperial period. ${ }^{8}$ Therefore, such side-effects of being the overlord of Islam's holiest land had to be handled with care, without harming the distinction that came along with it. In taking the steps needed to uphold this dignity, manifold letters, orders, reports, and missions shuttled across southeastern Europe and the Middle East; between the state and its appointees, between the Ottoman monarch and the Safavid shah, between the Empire's and Iran's grand viziers, between the borderland governors of the two states and so on. The documents discussed in the present study make up only a small proportion of this archival paper trail.

It is well known that Shah Abbas I had urged his subjects to visit the Imamic shrines within Iran instead of going on pilgrimage to Iraq and Arabia under Ottoman lordship, so as to forestall the outflow of money, and that the Safavids however forsook this policy soon afterwards. Later shahs backed up these westbound trips abroad, and therefore let this undertaking drain considerable amounts of money out of Iran. ${ }^{9}$ The Safavid 'ulama' in fact went so far as to write pilgrimage guidebooks to make Shiite Iranians better "informed of the virtues of visiting the [Sublime] Thresholds" in Ottoman Iraq, and therein heralded that at Judgement Day the Imams would plead for the heavenly salvation of those who had visited these shrines..$^{10}$ Iranian grandees even made endowments to finance their proxies (وكلي or the visit these shrines in their name, while the royal Endowments of the Fourteen Immaculates (موقوفات جهوم (و) kept on sending the specified share of its Isfahan-sourced income to those from the offspring of Husayn who dwelt in Medina and were Shiites.

7 S. Faroqhi, Herrscher über Mekka: die Geschichte der Pilgerfahrt (Munich: Artemis Verlag, 1990): 163-166.

8 G. Burak, "Between Istanbul and Gujarat: Descriptions of Mecca in the Sixteenth-Century Indian Ocean." Muqarnas 34 (2017): 290-294.

9 R. Matthee, Persia in Crisis: Safavid Decline and the Fall of Isfahan (London \& New York: I.B. Tauris, 2012): 218-219, 237-238; R. Matthee, "The Safavid-Ottoman Frontier: Iraq-i Arab as seen by the Safavids." International Journal of Turkish Studies 9/1-2 (2003): 166-167, 171172; Melville, "Shah 'Abbas and the Pilgrimage to Mashhad": 216-217.

10 M.B. Majlisī, Tuhfatu'z-Zā'ir (Tabriz, 1261 [1845]), page 3 and the unnumbered page [12] beginning with "Rizā alayh as-salām manqūl ..." and ending with "... pas bar xwābat" (from the copy at the Staatsbibliothek zu Berlin, 4" Zu 43964). 
Likewise, there among the outgoings of the Safavids' new Endowments of the Royal Seminary (موقوفات مدرسه سلطانى) was the expenditures for Thresholds and Sanctuaries (عتبات و حرمين), i.e. Najaf, Karbala, Mecca, and Medina." writs studied here also show how embedded the pilgrimage of Shiite Iranians had become in the economies of Imamic shrine towns of Ottoman Iraq by the mid-seventeenth century.

\subsection{Observations and Commentary: Political Stakes, Registration, Pilgrims, Diplomacy, and Sectarianism}

Documents on the shrines of Karbala and Najaf do not speak of a rivalry between factions, and yet reading between the lines reveals a different picture: appointments to the administration of endowments and grants from endowment income were often motivated less by concerns for public welfare than by factional power struggles - and the endowments for the Imams of the House of Muhammad in Iraq in the seventeenth and eighteenth centuries were no exception. The Martyria Endowment was a field of contest between two political networks in the Ottoman Empire.

One of these two networks may be called the governorate faction, for when it held sway, the governor of Baghdad and the treasury of the Baghdad governorate oversaw the Endowment as the link between the Endowment's holdings in the Iraqi countryside and the imperial auditing by the Chief Accountancy Chancery (باش محاسبه قلمى) in Constantinople. The Ottoman governor of Baghdad, installed by the imperial court, named the Endowment's trustee (متولى) and was answerable for the Endowment's financial bookkeeping. Within the other network, which may be called the palatials' faction, the Chief Eunuch of the Imperial Harem (دارالسعاده آغاسى) ran the Endowment as its overseer (ناظر) and hence determined its appointments and allotted its wealth; the Endowment was given exemption and autonomy مفروز القلم, مقطوع) (لفرم) from the control of the treasury of the Baghdad governorate;

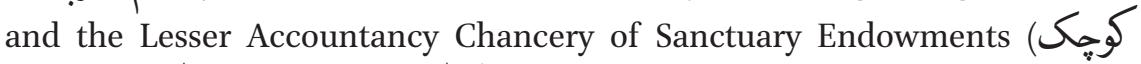
took on the auditing at the imperial finance department. ${ }^{12}$

Notwithstanding the posts and titles involved, the contest between these two networks for controlling the Endowment was not one between Baghdad and Constantinople, or between the central government and the province's governorate. This is for several reasons. First, the governor of Baghdad was at

\footnotetext{
11 Manșūr Șifat-Gul, Sākhtār-i Nihād u Andīsha-i Dīnī dar İrān-i 'asr-i Șafavì (Tehran: Khidamāt-i Farhangī-yi Rasā, hs. 1381): 322-327, 335.

12 IE. EV. $25 / 2938$.
} 
the time no less a dignitary of the Imperial Court than the chief eunuch of the palace. These governors too had stemmed from within the palace and imperial service, and even after they had been appointed to so eminent a position as, say, viceroy of Iraq, the future of their political career continued to depend on the Imperial Court. Moreover, as governors of Baghdad they were at the same time non-resident viziers of the Imperial Council. So, even if the province of Baghdad was geographically at the edge of the Empire, the governorate of Baghdad was institutionally no less Ottoman than the monarch's court.

Besides, both under governorate control and the palatials' oversight, the hierarchy to which the Martyria Endowment was subordinated ended up in the grand vizier, which further rules out a center-periphery strife. Between former, incumbent, and potential trustees of the Endowment, a fight to secure the revocation of the investiture of one's rivals and have oneself appointed instead (let us call these charter wars) likewise came down to the grand vizier's edict (بيورولدى) -notwithstanding whether the aghas of the Harem or the pashas of Baghdad oversaw the Endowment. ${ }^{13}$

Instead of being a center-periphery rivalry, therefore, the conflict was rather between two networks that were both within the imperial establishment. Sayyids (the offspring of the House of Muhammad through Ali) who dwelled in Iraq and the officers of the court of the governor himself keenly sided with the governor of Baghdad to hold sway over the Martyria Endowment. ${ }^{14}$ As part of the rival faction, the Harem eunuchs and the Halberdiers' Corps (aالطها (ج) ( جيلر / تبرداران backed up the Chief Eunuch to oversee the Endowment-one should keep in mind that the chief eunuch was already the overseer of the Empire-wide endowments for the Two Sanctuaries, namely the Kaaba in Mecca and Muhammad's shrine in Medina. Much as belonging to a corps, a pasha court, or a lineage carried weight in this strife within the imperial court for the control of the shrines of Ali and Husayn in Iraq, it was not the only determinant. The same strife as the one between these political networks could also break out as infighting among individuals within each of these networks.

What caused a group or individual to side with either the governor of Baghdad or the chief eunuch as candidate to run the Karbala and Najaf Martyria were patron-client ties, informed by considerations of how, where, and to whom the Endowment's resources would be allotted. This network

13 A. DVN. 54/11, 316/5o; EV. d. 45167; i̇. EV. 6/675; MHM. d. 104 / ent. 224; TSMA. E. 822/12; also see AE. AHMDIII. 119/11732.

14 A. DVN. 54/11; AE. SSÜL.II. 23/2324; MHM. d. 90 / ent 119, d. 96 / ent. 338; TSMA. E. 822/12, $833 / 25,1166 / 43,1412 / 76$; also see C.Ev. $63 / 3117$. 
could be so wide and the wealth thus dealt out so great that parties to this relationship could keep on sticking together even after their terms at the Endowment would end. Under governorate control, the governor of Baghdad pocketed the fixed "oversight money (نظارت آحقه سى)" as well as the conventional "courtly fee (قايو خربى)," to be shared between himself and his chief of staff (كدخد) (قلمية) of handsome amount was also paid from the Endowment's income to the governor nominating the trusteebe it a local sayyid or a non-local person. The treasurer of Baghdad too collected a further "courtly fee." Besides, the pasha of Baghdad's majordomo (مكيل) (خرج), stand-in (متسلم), retinue officers, welcome officers (خوشآمد آغالرى), sentry officers (ضواغول آغالرى), the magistrate (ضابط) of Hilla (a town to the south of Baghdad), and the chieftain of the House of Kasham (a local tribe) all took their separate shares from the Endowment's income in cash as well as in kind. This, then, was the constituency of people who had an interest in supporting the governor of Baghdad's wielding authority over the shrines in Karbala and Najaf. Under palatial oversight, the chief eunuch patronized his underlings and associates from within the palace court. A person of such affiliation would invest beforehand a handsome amount of money at the capital under the name of "rewards" (جوائز), which was a kind of investiture tax otherwise paid not before but after an appointment, and again "courtly fees," so that he could secure appointment to the trusteeship of the Martyria Endowment by the master of the padishah's harem. Once in Iraq, he first had to break even and then move into profit. Therefore the trustee named by the chief eunuch would sometimes withhold produce from the Endowment's crop-fields, issue fines to those dwelling on the Endowment's grounds, obtain personal gain from the holdings of the Endowment such as tax-farms, and sell the sinecures of the Endowment by auction. ${ }^{15}$

It made little difference to the state whether the Martyria of Ali and Husayn were subordinated to the Chief Accountancy Chancery through the governorate of Baghdad, or to the Lesser Accountancy Chancery through the chief eunuch's oversight. Both hierarchies ended up fiscally in the imperial finance department (دفتردارلت) and in the State Registry's (دفرخانه عامره) logs, and politically in the grand vizier's edict, sometimes even the padishah's handwrit (خط همايون), either way bringing forth an imperial charter (برات همايون). Which office of the imperial finance department audited the Endowment and which arm of the imperial court ran the Martyria made a difference in how the resources of this business in Iraq were steered and who benefited from 
them. But as for the state's lordship rights, both alternatives amounted to the same thing.

Among the uses of shrine endowments was the allotting of endowment wealth to build a patronage network between beneficiaries and the overseeing authority. The resources dealt out through Ali's and Husayn's endowments were great enough to give rise to local economies of their own in Najaf and Karbala, making the shrine, the town, and the surrounding countryside one and the same economic unit. To understand how central this was in the running of the Martyria, it is enough to look at how frequently free cash "stipends" (وظيفه), in-kind "allowances" (جرايه), and "holiday bonus" (عيدية) for the titular

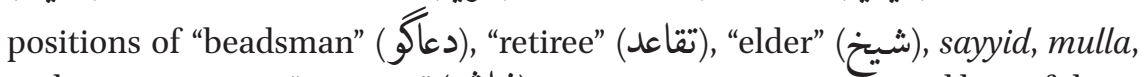
and to some extent "sweeper" (فواش), come up in transactions and logs of these shrine endowments. ${ }^{16}$

The term beadsman is the courtly name of a stipend-holder whose only function was to praise the patron(s), that is the governor or the chief eunuch, the grand vizier, and the monarch. So, beadsmanship was a symbolic conferral, a salary without any service for its recipients other than speaking up for the imperial court in the provinces, given to those whose non-opposition, owing to their potential influence, was worth securing with money, and to those who had won the favor of the monarch or one of his ministers. Having an imperial investiture of a post at the endowment made sure that the beadsmen would not have a hard time finding listeners. And being paid for this guaranteed that the beneficiary deemed being in good standing with the government the means of his livelihood rather than a burden on top of a day job. Bestowals of beadsmanship became overwhelmingly a way to reward in networks of favoritism, insomuch as to endanger the fulfillment of the original function of the funds from which these arbitrary conferrals were made. ${ }^{17}$ The retirees likewise were mostly the beadsmen who had become too old or sick to show up

16 AE. SsÜL.II. 23/2324; EV.HмH. d. 392, d. 397, d. 1861, d. 2584; Evliyâ Çelebi, Seyâhatnâme (Istanbul: Yapı Kredi Yayınları, 2011): 345a, 353b; íE. Ev. 6/687; мнм. d. 9o / ent. 119; TSMA. Е. 303/61, 822/12, 833/25, 1288/102, 1402/56, 1412/76; also see тSмA. E. 1132/38.

17 M. İpşirli, "Duâgû," Türk Diyânet Vakfı İslâm Ansiklopedisi 9 (1994): 541-542. See tSma. E. $302 / 3$ for a clear example of this relationship based on mutual interest embedded in the institution of "beadsmanship." In this letter from Abdülkerim the chief of Prophet Muhammad's sanctuary in Medina to a vizier Mustafa Pasha dated by the archivist to the year $165^{2} / 1653$, the sender states how he, upon receiving and dealing out to the entitled ones the padishah's yearly surre - treasury and "alms" to the Hejaz, gathered the clergy, dwellers, wayfarers, and visitors with the specific reason of praying publicly for the monarch, every week on Mondays and Thursdays, especially in Muhammad's shrine, and how these well-wishers of the padishah held a procession in glorification and veneration of the padishah. 
in public for propaganda, rather than pensioners who had formerly done real work for the Endowment. In other words, it was the norm that most "work" at shrine endowments amounted merely to the post-holder's swaying the public opinion on behalf of his patron.

Moreover, whenever the holder of a stipend or allowance died or willingly gave up the position, the Endowment sinecure left behind was normally bestowed upon his son. This we see in the appointment logs noting that the holder had taken over the post "from the vacancy of his father" (عن محلول يدرش), typically upon the father's death. If the holder wished to give up the sinecure while still alive, he then petitioned the imperial government saying that he "forsook" (فواغت his stipend or allowance from the Martyria for his "biological son" (صلى اوغلى) to take over. "Being the biological son of the deceased whose position became vacant" was deemed enough for the "biological son to be the entitled and rightful" replacement (وتوت اولوب يرى محلول اولماق إيله صلبى اوغلى مينى (18....... محل و مستحق اولمغين

On top of these job definitions and entitlements also came the exemption from some taxes for the sayyids dwelling in or near these shrine towns. ${ }^{19}$ So, the state, or the dignitaries of the state, not only created life-long ties of interest with local individuals but also turned provincial propagandism for the government, or for certain dignitaries, into a family trade that was handed down from father to son. Of course, what the state bestowed and what the Endowment's stipendiary pocketed were funds otherwise meant for the public good. These allotments were marketed as being for the public good, whereas they were indeed a transfer of wealth from the state to a few individuals in an unspoken but well-understood deal. This deal can also be understood as a means to build lasting bonds between far-away townships and the imperial court, in this case between the Iraqi countryside and the Empire centered in southeastern Europe. The state cannot have failed to see the Ottomanizing drive that came along with such ties.

Depending on which bureau of the imperial finance department audited the Martyria Endowments (and hence the shrines, mosques, affiliated buildings, paid positions, income sources, and alms-giving to dwellers and visitors of Najaf and Karbala), any process or transaction was logged into either "Baghdad's accounting register of the State Treasury دفتر محاسبه خزينه عامره) (بغداد)," or the "accounting register of the illustrious Endowment of the Two illustrious Martyria (دفتر خزينه اوقاف شريف مشهدين شريفين)," both kept at

18 C. EV. 63/3117; i̇E. EV. 4/399, 19/2287; TSMA. E. 833/25, 1166/43, 1288/102.

19 Al-Rubaye, "Bağdat Vakıfları (1534-1830):" 109. 
Constantinople. ${ }^{20}$ Besides, a new imperial survey of income sources for the Province of Baghdad brought forth the "new survey register (يكى تحرير دفترى)," which too logged the holdings, income, outgoings, and paid positions of the Endowment, and therefore served as another official reference for later processes. The State Treasury's accounting register of the Endowment and the new survey register of the Baghdad Governorate were the two authoritative logs, which later decrees, petitions, applications, and annotations rested

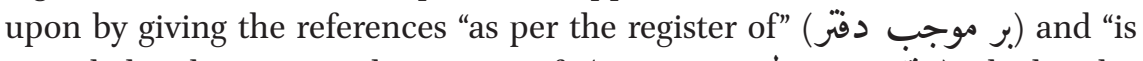
recorded and written in the register of" (دفترنده مسطور و مقيددر). The handover of the auditing from the Chief Accountancy Chancery to that of the Lesser Accountancy of Sanctuary Endowments likewise triggered a new specific survey of the endowments of Karbala and Najaf, for which the Imperial Court sent a surveyor and a palace Gatekeeper, and whose fulfillment brought forth a new survey register. ${ }^{21}$

The appointments not only of the Endowment's "prayer-leaders" (امام جامع) and "preachers" (خطيب) 22 but also its lower-ranking "sweepers" and "servants" (خدام) went through the official ladder starting from a village in Iraq and, passing through the provincial center, ended up wherever the Imperial Court then was, be it Constantinople, somewhere in the Balkans, or even Hungary. ${ }^{23}$ The transactions therefore involved offices, posts, and persons well beyond the pilgrims or the endowment personnel, and a geography much wider than the shrine towns. There were alternative procedures to run the processes, depending on whether the Imperial Court had the governor of Baghdad or the chief eunuch to oversee the Martyria. Either way, candidates would make known their willingness or rightfulness for positions to the official in charge.

At times when the Martyria were under governorate control, the director of the institution was the "trustee of the Endowment of the Two illustrious Martyria". For appointments under his watch, the trustee put forward the candidates with a "submission (عرض)" of his. This submission was sometimes laid before the governor of Baghdad, who then either rejected or installed the candidate by issuing his edict (بورولدى), and submitted the matter further to the grand vizier for approval along with a "Baghdad Treasury certificate بغد (خدرد) (خزينه سى تذكره سى (خ) vizier via a submission by the governor of Baghdad himself, without an edict

\footnotetext{
2 EV.HмH. d. 392, d. 397, d. 1861, d. 2584; IE. EV. 4/399; TSMA. E. 833/25, 1288/102.

21 AE. SsÜL.II. 23/2324; C. EV. 63/3117; EV. d. 45167; EV.HMH. d. 392, d. 397, d. 1861, d. 2584; їE. EV. 4/399, 6/675; 17/1972; TSMA. E. 303/61, 833/25, 1166/43, 1288/102, 1402/56, 1412/76.

22 IE. EV. 4/399.

23 İE. EV. 25/2938; MHM. d. 111 / ent. 1896.
} 
or certificate alongside it. The trustee himself was also appointed through the same steps. ${ }^{24}$

When the Martyria were under the oversight of the palatials' faction, by contrast, the directorship lay with the "inspector of the Two illustrious Sanctuaries (حرمين شريفين مفتشى)" of Mecca and Medina. This inspector, who managed the Empire-wide endowments for the Kaaba and Muhammad's shrine, presented nominations for positions before the "overseer of the Two illustrious Sanctuaries (حرين شريفين ناظرى)," who was the Chief Eunuch of the Palace Harem. The appointment, including that of the Endowment's trustee serving under the inspector, by the overseeing Chief Eunuch was then submitted to the grand vizier for approval. The trustee could give written submissions directly to the grand vizier if a decision by the overseer was not needed. ${ }^{25}$

Extraordinarily, even holders of any lower positions could skip the overseeing office and straightforwardly "petition" (عرضحال) the grand vizierate about, for example, the salary of the local chief of the House of Muhammad (عقيب) or that of the sayyid-chieftain of Husayn's shrine in Karbala, market fees, customs tolls, courtly dues, croplands, or workshops endowed to the Martyria. This could happen above all when the petitioner wanted the imperial court to override a decision made by the trustee or the inspector. ${ }^{26}$

Notwithstanding which faction controlled the Endowment of the Martyria, and even when an applicant bypassed his superiors in the hierarchy, all appointments and grants were in the end subject to the approval of the grand vizier. In general, the grand vizier's chief of staff (صدارت كدخدا سى) referred an incoming petition or submission to the imperial minister of finance (دفت كتردار) for him to write an informed "notification" (اعلام), and once it came back, either to the Chief Accounting Bureau in the case of governorate's control, or to the Lesser Accountancy Chancery of the Sanctuaries in the case of the palatials' oversight, for a "marginal annotation" (دركّار) of what was written in the state logs about the incumbency of the said position at the Endowment to be copied out. Exceptionally, the minister of finance himself could start the process by writing a submission to the grand vizier about the Martyria of Najaf and Karbala. ${ }^{27}$ After the referral came back to the grand vizierate from the finance and accounting departments, the grand vizier approved or rejected the appointment by writing his own edict. When a matter was too sensitive or controversial, the grand vizier instead wrote a "summarization" (تلخيص) of the whole

24 A. DVN. 54/11; EV. d. 45167; ï. EV. 6/675; MHM. d. 99 / ent. 424.

25 EV. d. 45167; İE. EV. 6/687; MHM. d. 104 / ent. 224; TSMA. E. 833/25, 1288/102.

26 TSMA. E. 303/61, 1166/43; AE. SSÜL.II. 23/2324; MHM. d. 90 / ent. 119 .

27 AE. SSÜL.II. 23/2324; C. EV. 63/3117; EV. d. 45167; İE. EV. 4/399, 17/1972; TSMA. E. 1402/56. 
story for the monarch himself to have the final say. In that case, the monarch wrote his handwrit atop the summarization. The grand vizier then forwarded the monarch's handwrit or his own edict, depending on by which command the matter was finalized, again to be logged into the relevant register and for an imperial charter to be issued to the appointee. Every finalized appointment, ranging in importance from the granting of a retirement pay to an Endowment stipend-holder to the more fundamental question of who should be made the trustee of the Endowment, was ultimately certified with an imperial charter of investiture. Among these items of correspondence were also conferrals of authority for officiating over Iranian pilgrims visiting the shrines. ${ }^{28}$

The documents bear witness that visitors from Iran could directly appeal to the Ottoman grand vizierate, signing their petitions collectively as the "pilgrims of 'Ajam (جاج عجم)," as they were also called by the Ottoman state and the Safavid state. Alternatively, one or a few pilgrims from Iran could separately send petitions underwritten with their names and status as Iranian pilgrims. When claiming a right from Ottoman authorities, Iranian pilgrims cited prior imperial decrees (فومان همايون) that were still in force, or asked for the issue of a new imperial decree addressed to their deputy as well as agha, so that they might have their right officially logged in writing ready for citation in some future instance. ${ }^{29}$ Both the deputy, whom the pilgrims chose from among themselves, and the agha, whom the Sublime Porte appointed upon the pilgrims, could "submit" matters straightforwardly to the grand vizier, if a settlement could not be reached with the judge and the governor of the province. Even the lower-ranking "packer" (ع ع ام باشى) was appointed through these channels and the fulfillment of this appointment needed an imperial decree. The imperial government bestowed, not the post but, the title and "rank of

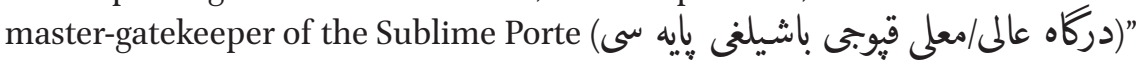
upon the Iranian deputy of the pilgrims, so as to set his standing within the Ottoman hierarchy. As a token of how significant the bestowal of this rank was, the deputy "petitioned (عرضحال)" the grand vizierate before receiving it, but wrote a "submission (عرض)" to the grand vizierate once he was made a

28 A. DVN. 257/5-6; AE. SSÜL.II. 23/2324; C. EV. 63/3117; EV. d. 45167; İ. EV. 4/399, 19/1972, 19/2287; M HM. d. 112 / ent. 583, 587-588, d. 117 / ent. 77O-771; TSMA. E. 303/61, 822/12, 833/25, 1288/102; also see мнм. d. 118 / ent. 139 o.

29 A. DVN. 340/18, 346/18; MHM. d. 110 / ent. 886-887, ent. 1259, d. 111 / ent. 1896; also see A. DVN. 316/14; 'Abdulḥusayn Navāī (ed.), Asnād u Mukātabāt-i Siyāsīi İrān az sāl-i 1105 tā 1135 h-q (Tehran: Muassasa-i Mutālacāt u Tahqīqāt-i Farhangī, hs. 1363): 175. Also see мнм. d. 110 / ent. 1754, 1756, 1762-1764, 1767, 1770; MH M. d. 111 / ent. 452, 853, 1122-1133. 
court officer ${ }^{30}$ (the same differentiation was in place in appeals to the imperial government by the Empire's subjects, who wrote petitions, and by Ottoman officials, who wrote submissions). Iranian pilgrims, sometimes through "their caretaker and legal deputy (امين و وكيل شرعيلرى)" could even appeal directly to the imperial court for redress of their grievances. ${ }^{31}$ The fact that this channel was open to them, and that the imperial government accorded their deputies formal Ottoman titulature, hints that although Iranian pilgrims were not declared to be Ottoman subjects, they were not seen as foreigners either. Ottoman law applied to them almost unreservedly.

Likewise, Ottoman judges in the provinces heard and ruled on the cases between the Iranians themselves. Lawsuits between Iranian visitors and their former representatives were also settled by means of the Ottoman judiciary and logged into courthouse registers. Sometimes, Iranians already dwelling in the Empire could undermine the undertaking of the incoming pilgrims from Iran, for instance by swindling the caravan. Just as in complaints from Iranian pilgrims about Ottoman authorities, service providers, or subjects, such cases too were settled by the governor and the judge of the province or the county (سنجاق), not only in the borderlands of Erzurum, Kars, Van, Diyarbekir, and Baghdad but also in Aleppo, Damascus, Jerusalem, Gaza, and Ajlun, usually at the behest of an imperial decree. Ottoman judges not only heard the cases of Iranian pilgrims but also saw to the works on pilgrimage buildings: the imperial court had the judges examine and oversee the renewals done at these works. Judges likewise logged such projects on pilgrimage sites into their courthouse registers and issued judicial deeds on matters concerning pilgrimage at and endowment of the shrines. ${ }^{32}$ They thus functioned as notary public and official witness in the framework of these shrines frequented by Iranians. By this means they also wrote down the minutes of relevant sittings of the governor's council and courthouse hearings, besides auditing shrine-related commissions in the field and registering the findings.

In one exceptional practice, though, the Ottoman state differentiated Iranian visitors from imperial subjects. The pilgrims in the Iranian caravan that used the Iraqi road had to hire escort troops from the governor of Basra to protect them from Bedouin onslaughts while going to and coming back from the

3 A. DVN. 251/2, 257/5-6; MHM. d. 119 / ent. 831, d. 122 / ent. 195. Also see A. DVN. 289/36; C. DH. 164/8165; MHM. d. 104 / ent. 53-55.

31 MHM. d. 102 / ent. 822. Also see MHM. d. 102 / ent. 852.

32 A. DVN. 64/33-34, 249/27, 251/2, 316/50, 346/18; íE. EV. 13/1576; мнM. d. 102 / ent. 724, ent. 821 , ent. $827-83^{2}$, ent. $850-852$, d. 108 / ent. 6o3, d. 110 / ent. 556, ent 558 , ent. 888-89o, ent. 1259, ent. 1793, d. 112 / ent. 1430, d. 118 / ent. 1172, d. 120 / ent. 824-826, d. 122 / ent. 195; TSMA. 833/25. Also see İ. EV. 41/4635; MHM. d. 110 / ent. 886-89o, 1793. 
Hejaz. The reason for this was that they could not bring guards from Iran into Ottoman territory, and as they were not imperial subjects, the Ottoman officials' protecting specifically them counted as extra service. In return for this, the Iranian subjects at the caravan had to pay an additional fee, whereas the Shiite Ottoman subjects who had joined the Iranian caravan while it passed through Iraq did not pay this fee, as the Ottoman authorities were already responsible for taking care of them. ${ }^{33}$

Though the Safavid state did not have a permanent diplomatic mission in the Ottoman Empire, the pilgrims coming from Iran did not need one to deal with the imperial government or its provincial officials either. The Sublime Porte readily dealt with the Iranian pilgrims as a corporate body to which the Empire's law applied. Any special, extra-territorial, or international status that Iranian pilgrims may have had in Ottoman lands was not represented by the Safavid State. They were rather subject to the Ottoman judiciary system that rested upon a blending of the monarchic law, sharia courthouse regulations, and decrees. The same is true for the provincial judges' functioning as notary public in matters on the pilgrimage shrines much visited by Iranians as well. These findings call for further studies on the law of subjecthood, extraterritoriality, and neighboring polities in the early modern Islamdom. However, one must beware of potential pitfalls when looking for connections between the information presented here from pre-modernity and the concepts of nationality, extraterritoriality, and alienage from modern times. ${ }^{34}$ In early modernity, there was subjecthood rather than citizenship or nationality for persons, and a legally unequal hierarchy rather than a principle of equality for independent polities. Besides, some non-subjects could well have a hybrid status, which may be called non-alien outsiders and which could arise from not only laws or treaties of exception but also unwritten conventions and unspoken understandings.

It passes as conventional knowledge that the policy of the Ottoman state towards pilgrims coming from Iran was to let them in but have them link up with the main caravan, which travelled over Syria, instead of taking the Iraqi road. ${ }^{35}$ While this may have been the Ottomans' initial course of action in the

33 M. Amhazūn, al-Madīnatu'l-Munavvara fì Riḥlatu'l-Ayyāshī (Kuwait: Dāru'l-Arqām, h. 1406): 187-189 as relayed in as R. Jafarian, Șafaviya dar 'Arsa-i Dīn, Farhang u Siyāsat II (Pizhuhish-gāh-i Hauza vu Dānishgāh, autumn 1389 hs.): 830-831.

34 For a study of how the modern concepts of nationality, citizenship, foreignness, jurisdiction, and extraterritoriality applied in the late Ottoman Empire, see L. Can, Spiritual Subjects: Central Asian Pilgrims and The Ottoman Hajj at the End of Empire (Stanford, CA: Stanford University Press, 2020): especially pages 7, 10-12, 15, 27, 96, 100, 103-104, and 111. Faroqhi, Geschichte der Pilgerfahrt, 180-184; S. Winter, The Shiites of Lebanon under Ottoman Rule (Cambridge University Press, 2010): 27; N. Shafir, "In an Ottoman Holy Land: 
mid-sixteenth century, by the mid-seventeenth century this was no longer the case. By that date, the Empire was permitting Iranian pilgrims to use the Iraqi road, and appointed for this highway a third pilgrimage commander, like those of the Syrian and the Egyptian roads. Many documents indeed show that the Ottomans even encouraged the Iranians to visit the Imamic shrines in Iraq. Through stipends, gifts, buildings, oversight, endowments, administration, and visitation by dignitaries, the Ottoman state invested in the upkeep of Najaf, Karbala, Samarra, and Baghdad within the network of the holy spots of the Empire next to Mecca, Medina, and Jerusalem.

Whereas the pilgrims' contacts with Ottoman subjects, authorities, and the administration of the pilgrimage caravan were matters subject to imperial law, the larger question of whether or not to authorise the dispatch of pilgrim caravans from from Iran to the Ottoman Empire was still a business of diplomacy. For example, the Safavid court in Isfahan and the Ottoman governorate of Baghdad together appointed the "pilgrimage commander" (امير ج) of the Iranian caravan that travelled over the Iraqi road. The two sides also worked together on the early organization of a forthcoming convoy. This, as much as being a subject-matter of the highest level of Ottoman-Safavid diplomacy between the padishah, the shah, and their grand viziers, concerned at least as much the borderland governors of, above all, Erzurum and Baghdad, who dealt not only with their cross-border Safavid counterparts but also directly with the shah's prime minister. ${ }^{36}$

In Iran, both the pilgrims as a whole and individual dignitaries, including vassal princes, had to get the shah's permission before setting out westwards. ${ }^{37}$ The shah's own officials, such as the royal superintendent, the chief of household staff, or the privy armor-bearer, and other prominent figures, such the grand vizier's son, could also join the pilgrimage caravan, ${ }^{38}$ but did so in a private capacity, without any acknowledged authority over the pilgrims while in Ottoman territory. The last word on the Iranian caravan's setting out toward Ottoman lands belonged of course to the shah, for the undertaking was more

The Hajj and the Road from Damascus, 1500-180o." History of Religions 6o/1 (2020): 17.

36 N.H. Murtazâ Efendi Bağdâdî, Münşeât-ı Nazmizâde (Süleymâniye Yazma Eserler Kütüphânesi, Esad Efendi n. 3322): 38b-39b; Asnād u Mukātabāt-i İrān 1105 1135: 174-175. Also see A. мкт. 1/56.

37 M.I. Nasīrī, Dastūr-i Shahriyārān, ed. M.N. Nasīrī Muqaddam(Tehran: Bunyād-i Mauqūfāt-i Doktor Maḥmūd Afshār, hs. 1373): 122-123.

38 'Abdulḥusayn Khātūnābādī, Vaqāyỉu's-Sinīn va'l-A'vām, ed. Muḥammad Bāqir Bihbūdī (Tehran: Kitāb-furūshī-yi Islāmiya, hs, 1352): 534; Journal of Zak'aria of Agulis, trans. and ed. George A. Bournoutian (Costa Mesa, CA: Mazda Publishers, 2003): 110; Nasīrī, Dastūr-i Shahriyārān: 26o. 
than just a civilian journey abroad and it bore diplomatic as well as political significance.

Another Iranian caravan, which came in from Yerevan and linked up with the imperial convoy in Damascus by faring over the Erzurum road, was led by an officer bearing an imperial charter. This leader dealt not only with the Ottoman court and governors but also with the Safavid governor of Yerevan/ Chuqursa'd, and through him did the said borderland governors of Iran and the Empire exchange letters, vouchers, etc. ${ }^{39}$

For the local economies of Karbala and Najaf, the inflow of Iranian pilgrims to and through Iraq was remarkable. One can liken this to the Indian pilgrims in the early modern Hejaz, where the local establishment saw them and the Mughal court as "milk cows," and took care to keep up the yearly inflow of pilgrims (who spent well and were taxed heavily), royal donations, gifts, alms, and other kinds of charity. ${ }^{40}$ An unusual drop in the number of Iranians visiting in a given year would lead to a notable fall in earnings of the Martyria Endowment from some of its income items such as tax farms (مقاطعات), the inn, the sale of rosaries and of shrouds, and the estates (ييت المال) of those Iranians who bequeathed their wealth to these shrines. On top of these came the "vows" (نذورات) in cash and in objects made of gold or silver, not only from actual Iranian visitors but also from individuals in Iran, even the shah himself, who did not come themselves but sent their alms, and the revenues from burying dead Iranians into graves next to the shrines. Neither vows nor burial revenues nor estates seem to have depended on how many Iranians came in a given year, because the aforesaid money and corpses were mostly shipped from Iran, without the need for the donor to visit or for the bequeather to die while in Ottoman Iraq. ${ }^{41}$ Among the countless bodies thus brought from Iran to Karbala or Najaf for burial, because these people had bequeathed their wealth to the Martyrdom Endowment and their bodies to the graves at the shrines of Ali or Husayn, could be well-off commoners, elite non-officials, and royal officers, as high as a grand vizier of Iran dying while in office. ${ }^{42}$

The management of the Iranian pilgrims in the Empire sometimes became a subject of what one could call Ottoman internal diplomacy, between the

39 AE. SAMD.III. 119/11732.

40 M.N. Pearson, Pilgrimage to Mecca: The Indian Experience, 1500-1800 (Princeton: Markus Wiener Publishers, 1996): 115-116, 121, 173-174.

41 Ev.HmH. d. 392, d. 397, d. 1861, d. 2584; Evliyâ Çelebi, Seyâhatnâme: 345a, 349a, 353b. See also S. Ateş, "Bones of Contention: Corpse Traffic and Ottoman-Iranian Rivalry in Nineteenth-Century Iraq." Comparative Studies of South Asia, Africa and the Middle East 30/3 (2010): 512-532.

Khātūnābādī, Vaqāyi: 519, 564 . 
imperial court and vassal princes. In the monarch's writs to the princes of Mecca, a letter in form but a decree in content, it was stressed that with the shah of Iran peace was in force, which the prince also had to abide by, and owing to which the Iranian pilgrims were not to be burdened with unlawful exactions in the Hejaz. These decree-like letters never brought up the sectarian identity of the Iranian pilgrims, whom, just as the rest of the Muslims, the prince of Mecca was to take good care of. ${ }^{43}$ The Safavid court itself could also

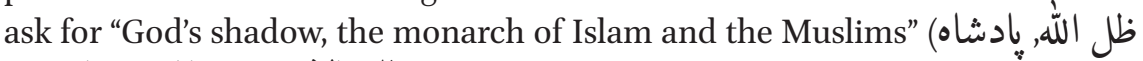
(سلطان الاسلام و المسلهين اسلام, of the "Caliphate" (خلافة), that is the Ottoman ruler, to command the prince of Mecca and the pashas of other provinces that they not charge the "pilgrims of Ajam" more than the conventional amounts for fees, and about almost any matter that concerned the Iranian pilgrim caravan and its officer. ${ }^{44}$ Safavid shahs also corresponded with the princes of Mecca in formal exchanges of courtesy, though not through missions but by means of travelling pilgrims.$^{45}$ The Safavid court must have resorted to Constantinople's sway over the Hejaz when an issue relating to pilgrims could not be settled through these letters of courtesy to Mecca.

The Safavids' showing such reverence to the Ottomans was in line with the overall course of the diplomacy between the two states in the later seventeenth and the early eighteenth centuries, in which the Safavids were acknowledging the Ottoman monarch's universal caliphate, exchanging prayers with the Ottomans for sharing heavenly remuneration, and defining the relationship between the two courts in a Quranic framework. In the same vein, the Islamic ulama became stripped of their role in Ottoman-Safavid diplomacy so that their doctrinal positions not undermine the rapprochement, while politicians and bureaucrats took it upon themselves to utter in diplomatic dealings the Quran and Muhammad's hadith in a way that backed up, rather than hindered, the growing friendship. As a matter of course, between the Ottoman and the Safavid states, there was no longer the talk of doctrine, orthodoxy, or sectarianism. ${ }^{46}$

The Safavid monarchy also drew on its diplomacy with the Sublime Porte to facilitate its access, albeit indirect and limited, to the Imams' shrines and the

\footnotetext{
43 NMH. d. 5 ent. 78, 86, 98; MHм. d. 102 / ent. 171 (on page 42); also see A. DVN. 281/28.

44 Asnād u Mukātabāt-i 1105 1135: 172-176. Also see A. DVN. 307/77; MH M. d. 110 / ent. 916, 1769; мнм. d. 111 / ent. 258.

45 R. Ja'farian, Kāvishhā-yi Tāza dar Bāb-i Rūzgār-i Șafavì (Qum: Adyan Publication, 2nd edition, hs. 1393): 238-244.

46 On this topic, see S. Güngörürler, "Islamic Discourse in Ottoman-Safavid Peacetime Diplomacy after 1049/1639." In Historicizing Sunni Islam in the Ottoman Empire, c. 1450c. 1750, ed. T. Krstić \& D. Terzioğlu (Leiden: Brill, 2020): 479-500.
} 
Martyria Endowment in Iraq throughout the late seventeenth and the early eighteenth centuries. The shah's low-key request, presented by his ambassador to the Ottoman court, for the padishah's authorisation as a one-off to renew the sarcophagi of Imams Ali al-Hadi and Hasan al-Askari in Samarra was granted and enacted as an imperial decree. ${ }^{47}$

Likewise, the Iranian grand vizier's request, forwarded in his letter, for one-off authorisation to set up the new Safavid-made sarcophagi of Imams Musa al-Kazim and Muhammad al-Taqi near Baghdad was granted through the Ottoman grand vizier's answer and enacted as imperial decrees. On the other hand, the bold request that the shah's functionaries be henceforward authorized to renovate, donate to, and deal out alms at Iraq's Imamic shrines, without showing a license to provincial officials or applying for a new license from the imperial court each time, was categorically rejected. ${ }^{48}$

Lastly, the Iranian grand vizier asked, through his letter and in the name of the shah, for the Ottoman monarch's permission to dig a water canal from the eastern Euphrates to Ali's shrine-town of Najaf. Along with this came Safavid attempts at two faits accomplis: first, Isfahan sent to Karbala an "amir" to work there side by side with the Ottoman trustee of the Martyria, to bring the Safavid endowments' money from Iran and spend it towards the Martyria, and to deal out the shah's donations there for all to see, and wanted to have the Ottoman monarchy make room for this Safavid-installed co-trustee. Next, the shah's armor-bearer brought to Medina a bejewelled pastille (مرصع شامه) as a gift from the shah but the officials there did not let him set it up within Muhammad's sepulcher on the grounds that imperial authorisation was lacking. The grand vizier of Iran asked for the Sublime Porte's licence for this initiative too. ${ }^{49}$ The Ottoman grand vizier, remarking that nothing could be put or raised in Medina without the padishah's permission, accepted the gift itself but forbade the shah's armor-bearer to set it up on site, handing the matter with an imperial decree over to the padishah's pilgrimage superintendent instead. The shah's afore-mentioned digging open a river canal to Najaf, on the other hand,

47 For the events in question, which took place between 1696 and 1701, see MHM. d. 111 / ent. 1694; N. Murtazâ Efendi, "Sefer-i Basra," ed. Vahid Çubuk in "Nusret-name’nin Kaynaklarından Tarih-i Seferü'l-Basra," İstanbul Üniversitesi Edebiyat Fakültesi Tarih Enstitüsü Dergisi 15 (1995): 331-338.

48 See мнм. d. 112 / ent. 1218; NMH. d. 5 / ent. 218, 220; R. Mehmed, Münşeat (Österreichische Nationalbibliothek H.O. 179): ff. 23a-24a; Asnād u Mukātabāt-i 1105 1135: 82-86. See AE. SAMD.III. 208/20076; Mehmed, Münşeat: ff. 24b-25a; A. DVN. 305/23. 
was rejected not only categorically but also with sarcasm for even daring to ask of such a thing. ${ }^{50}$

Documents from manifold genres all agree on one thing: they do not bear the marks of any Shiite-Sunni feud that may have been there in the minds or lives of those involved in these operations. (Remarkably, this seems to have been the case even at times when a sectarian strife broke out, such as when the Ottoman-subject Shiite dwellers of Karbala openly worked to thwart the functioning of the Martyria Endowment's trustee installed by the Sunni state, to the extent that even the Shiites coming from Iran deemed the Shiite Karbala dwellers' behavior against imperial appointees unduly hostile $\left.{ }^{51}\right)$. If anything, the authorities of the officially Sunni empire and the pilgrims coming from the officially Shiite Iran fostered a shared, if not the same, veneration for the Imams whose shrines had become pilgrimage spots.

Representatives of the Sunni empire called the shrines of Ali (Muhammad's cousin and in Shiism his only rightful successor by God) in Najaf and that of Husayn (Ali's second son as well as second successor) in Karbala the Two illustrious Martyria. These two saints almost never come up in the documents without the titles and honors that, while also acknowledged in Sunnism, makes up the credo in Shiism: "his Holiness Imam Ali / Husayn" (حضرت امام على /حسين). Another way of paying the same respect was, for instance, calling them the "pure-lineaged and evidently-righteous Imams who bestow honor upon the

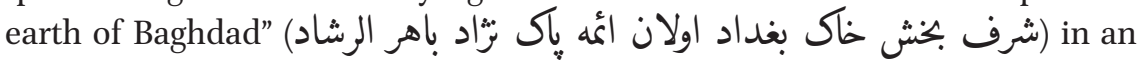
imperial decree to Baghdad's governor and judge for them to take good care of the Iranian pilgrims visiting the shrines. ${ }^{52}$

There is likewise not even one utterance of or hint at sects, Shiism/Sunnism, unbelief, heresy, or sin towards the Shiite Iranian pilgrims or Safavid officials, let alone for the House of Muhammad, the Twelve Imams, their offspring, or followers. The Empire acknowledged the otherwise Shiite pilgrims only in that they "circumambulated the sacred House of God" (طواف بيت الله الحرام) and "performed the obligatory Pilgrimage and visited the honorable Martyria and the blessed Sepulchers" (اسقاط/اداء فريضه ج.... زيارت مشاهد مشرفه ومراقد متبرك). The visitors themselves were likewise called "salvation-faring / joyful pilgrims" (جاج فلاح منهاج / ذو الابتهاج), and in documents about pilgrimage, the overall

$50 \quad$ A. DVN. 305/49; Râmî Mehmed, Münşeat: ff. 25a-26a (ent. 37).

51 Nasīrī, Dastūr-i Shahriyārān: 284-285.

52 A. DVN. 316/50; AE. SSÜL.II. 23/2324; C. EV. 63/3117; EV. d. 45167; EV.HMH. d. 392, d. 397, d. 1861, d. 2584; Evliyâ Çelebi, Seyahatnâme: 345a; İE. Ev. 6/687, 19/2287, 25/2938; мнм. d. 90 / ent 119, d. 96 / ent. 338, d. 104 / ent. 224, d. 112 / ent. 1234; TSMA. E. 303/61, 822/12. 
name "Muslims" encompassed, among others, the Shiite pilgrims from Iran too. ${ }^{53}$ It was not odd at all for Ottoman governors and finance ministers of Baghdad to donate handsome amounts of money and material to the Karbala and Najaf endowments, and renew its buildings, from their own pockets. ${ }^{54}$

This does not necessarily all mean, of course, that in the period under discussion there happened no strife between the Shiite and Sunni sects of Islam. But even if sectarian disagreements still existed, they seem to have mattered little to the Sunni states' politicians or bureaucrats, or the Shiite pilgrims' spokesmen in their dealings with one another. Each side was in all likelihood well aware of the deep-rooted rift between the Shiite and the Sunni beliefs, but deemed it not so important as to be brought up in governmental writs, or at least they deemed it wise not to do so with an eye to mutual political interests. Either way, the non-clergy members of the Shiite and the Sunni establishments could easily play down their differences when dealing with one another even in a religious business. That the ulama seems to have been wholly left out of the Shiite-Sunni pilgrimage organization, on which they neither had a say nor were consulted, also hints at a prioritization of practicality over doctrinal niceties.

On the other hand, this reverence by a Sunni establishment towards those whom Shiism regarded as its own pillars should not be mistaken as a hidden sympathy by Ottoman/Turkish Sunnism towards Twelver Shiism. Many scholars give in to this misreading, ${ }^{55}$ which arises from a rather modern trend of failing to acknowledge the unbridgeable difference between Qızllbashism and Shiism. For the Ottomans (i.e. in the Anatolian-Balkan tradition of Sunnism, and still in today's Turkey), venerating the Imams of the House of Muhammad, highlighting the rightful caliphates of Ali and Hasan, exalting Imam Husayn, deeming Imam Jafar as-Sadiq an authority for his jurisprudence work, and acknowledging the Umayyad-Abbasid oppression of the Imams, to the extent of having Ali's legendary sword Zulfiqar on the banners of Court Corps (قود) (قود)

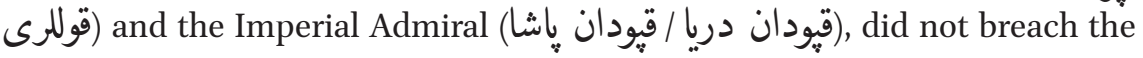

53 A. DVN. 249/27, 251/2, 257/5-6, 314(316)/26; AE. SAMD.III. 119/11732; MHM. d. 102 / ent. 176 (on page 42) ent. 724, ent. 821, ent. 827-832, ent. 850-852, d. 108 / ent. 6o3, d. 112 / ent. 143o, d. 119 / ent. 832-833, ent. 1098, d. 120 / ent. 824-826, d. 122 / ent. 195; Nazmizâde, Münşeât: 38b-39b; NMH. d. 5 / ent. 86.

54 TSMA. E. 822/12.

55 This includes even leading researchers of the field, such as Rasool Jafarian, as to be seen in his Șafaviya dar 'Arsa-i Dīn, Farhang u Siyāsat I (Pizhuhish-gāh-i Hauza vu Dānishgāh, summer 1391 hs.): 19, 35-36, 38, 87 . 
tenets of Sunnism, hint at a leaning towards Shiism, or even cloud the distinctions between sects. ${ }^{56}$

The Ottoman state seems to have dealt with the Shiite pilgrims from Iran in keeping with its general policy of not officially acknowledging non-Sunni groups as corporate communities but treating them "as if they were Sunnis" without explicitly identifying them as such. The Ottoman state's Sunnitization drive and the parallel sharpening of confessional identities within society had begun before the rise of the Safavid polity, and they went on after the end of the Ottoman-Safavid conflict. ${ }^{57}$ Even if one accepts that the Ottoman Empire went through a "confessionalization" akin to, albeit not the same as the one that unfolded in the German lands from the mid-fifteenth century to the midseventeenth, ${ }^{58}$ the documents examined here strongly suggest that sectarian issues were taken off the agenda of the peacetime contacts between the Ottoman Empire and Safavid Iran.

The Ottoman state's main, and perhaps only, concern about the incoming Shiite pilgrims from Iran was that they were not to mingle with the local Shiite dwellers of the places they visited or passed from. To forestall any such interaction, they went to the length of investing to improve the quality of lodging provided in shrine towns, thus to disincline pilgrims from staying elsewhere. Otherwise, the Ottoman state does not seem to have been bothered by donations from Shiite Iranian sources and income stemming from the visiting Shiite Iranians for the Karbala and Najaf endowments. Instead of forbidding them, the Ottoman state chose to overshadow such donations by spending even greater sources in donating to and building up Ali's and Husayn's shrines. ${ }^{59}$

56 V. Erginbaş, in his "Problematizing Ottoman Sunnism: Appropriation of Islamic History and Ahl al-Baytism in Ottoman Literary and Historical Writing in the Sixteenth Century." Journal of the Economic and Social History of the Orient 6o (2017): 618, 619-621, reads Ahlulbayt-friendly streams within Sunnism as confessional ambiguity and blurry sectarian lines. I disagree with this reading, for Ahlulbayt-friendliness in the Turko-Persian tradition of Sunnism has rather been in the mainstream, and bore no implication of a leaning towards Shiism.

57 D. Terzioğlu, "How to Conceptualize Ottoman Sunnitization: A Historiographical Discussion." Turcica 44 (2012-2013): 305, 313, 318, 320, 322.

58 T. Krstić, Contested Conversions to Islam: Narratives of Religions Change in the Early Modern Ottoman Empire (Stanford, CA: Stanford University Press, 2011): 12-15, 96-97; R. Ylldırım, "The Rise of the 'Religion and State' Order: Re-confessionalization of State and Society in the Early Modern Ottoman Empire." In Ottoman Sunnism, ed. Vefa Erginbaş (Edinburgh: Edinburgh University Press, 2019). Winter, Shiites of Lebanon under Ottoman Rule: 27; Faroqhi, Geschichte der Pilgerfahrt: 186. 


\section{Acknowledgments}

I am grateful to the three JESHO reviewers for their insightful comments and constructive criticism. This research was funded in whole by the Austrian Science Fund (FWF) [P 32696-G]. For the purpose of open access, the author has applied a CC BY public copyright licence to any Author Accepted Manuscript version arising from this submission.

\section{$2 \quad$ Text Edition}

\section{Translation}

Document 1 (iE. EV. 6/675)

submission, marginalia, and edict

[I: submission]

To the ground of the Court orbited by the sky and the Audience of heavenly might, submission by this powerless servant is as follows

Your servant Sayyid Zayd, who currently is the trustee of the endowment of the Illustrious Martyria located at Baghdad, is the initiator of this submission of servitude. All of the former as well as direct stipendiaries [of the endowment] are satisfied with and thankful to him; [he] strives to build up the aforesaid endowment; he is the current holder of the aforesaid trusteeship. The request to reconfirm [his trusteeship] and to bestow a sublimely glorious, illustrious Charter upon his hand is submitted to the Stately Court. Nonetheless, the decree is of the justice-titled Gate.

Your servant Ibrahim

[II: referral by the grand vizier's chief of staff] ITS PLACE [IN THE RECORDS] SHALL BE SEEN.

[III: retrieved records annotated on the margin]

In accordance with the Treasury register:

The trusteeship of Imam Husayn his Holiness, may God be pleased with him, in the province of Baghdad, held by Sayyid Zayd, in accordance with the petition by Sayyid Abbas the overseer of the aforesaid endowment, note for charter given on 30 July 1665, and with the copy of the imperial tenure issued on July 26 of the same year. 
That the aforesaid trusteeship is assigned on the afore-mentioned person is written in the register. Decree is Yours, my blissful and eminent Sire. On 22 May 1667

[IV: grand vizier's edict] AUTHENTIC. To approve again and reconfirm accordingly is COMMANDED. On 23 May 1667

\author{
Document 2 (A. DVN. 54/11) \\ submission, marginalia, and edict
}

[I: submission]

To the ground of the Court orbited by the sky and the Audience of heavenly might, may its sublimity not decline until Doomsday, the submission by this powerless servant is as follows

Your beadsman Sayyid Abdulaziz from among the noble Sayyids, who bears this submission of servitude, has, since the imperial conquest and with the illustrious Charter of high glory, been the trustee at the endowments of Imam Ali his Holiness, Imam Husayn his Holiness, and Imam Musa Kazim his Holiness, may sublime God be pleased with them, located in the province of Baghdad. There has been no shortcoming of his in the required service that pertains to the trusteeship of the said endowment. A non-affiliated person named Abbas, who is known for being a heretic and who earlier was at the side of the Kuzllbaş of evil-livelihood, now gave, while his brother and nephew are [still] alongside the shah, false notification and had the aforesaid trusteeship chartered upon his relative named Sayyid Zayd with a majestic imperial handwrit. Aside from wholly violating the above-written one in this way, they themselves are eating from the wealth of the aforesaid endowments. A request is [hereby] submitted for the worldwide-obeyed Decree that the aforesaid Abbas and Zayd be removed, the mentioned trusteeship be reconfirmed back to the above-written beadsman of Yours, the illustrious Charter of high glory be bestowed upon his hand, and the charters that the aforesaid ones received by false notification be taken back from their hands and be sent to the Stately Court. Nonetheless, decree is of the Court of righteousness.

Your servant Mustafa

[II: retrieved records annotated on the margin ] 
Trusteeship of the endowments of Imam Ali, Imam Husayn, Musa Kazim, and Muhammad? their Holiness, at Baghdad:

\section{held by Sayyid Abdulaziz:}

In the register it is written that

While the trusteeship of the mentioned endowments was upon him, the unaffiliated person named Abbas took and interfered with it. Whereas the aforesaid Sayyid Abdulaziz had previously been approved and the highlyglorious Charter had been given to his hand, he [Abbas] had not contented himself but interfered again. Therefore, in accordance with the charter in his [Abdulaziz's] hand, it [the trusteeship] was reconfirmed to the mentioned Sayyid Abdulaziz on the eighteenth day of September of [sixteen] sixty-eight in accordance with the imperial tenure copy.

Decree is Yours, my blissful and eminent Sire.

On 27 January 1669

[tailed signature of the minister of finance]

[III: grand vizier's edict]

AUTHENTIC. It is COMMANDED to write a decree to the guardian of Baghdad - the revered vizier, the blissful, high, and eminent Mustafa Pashafor [Abdulaziz's trusteeship] to be likewise approved, and for the protocols in Abbas's hand to be pursed and dispatched to the Imperial Court; as at the Threshold of Bliss it [the trusteeship] is on Sayyid Abdulaziz. On 31 January 1669

Document 3 (IE.EV. 13/1576) judicial attestation

\section{He!}

Hifzi Abdurrahman b. Ayub, judge of the city of Baghdad, the abode of jihad protected from the opposers

The reason for composing this writ is as follows

The women's mosque and the hall of Quran-memorizers at the shrine of Imam Husayn his Holiness, may Sublime God be pleased with him, as well as the women's mosque and the upper dome of the illustrious sepulcher at the shrine of Imam Abbas his Holiness, need repairs. Hence, Sayyid Abdulaziz the trustee of the mentioned endowment had previously made a reconnaissance that "the above-mentioned repair is doable with eighteen purses [of money]," and, as written, submitted it in notification to the Council of Baghdad. Then, I the 
poor one went actually to the afore-mentioned site together with the pride of the peers Mehmed Agha, who is the commissary appointed illustriously by governor-general of the province of the blissful Baghdad, Mustafa Pasha his Excellency the glorious minister the Asif-signed vizier the administrator of the world's affairs the completer of the shortcomings of the nations the owner of the golden opinion the possessor of firm idea, with crown architects Haji Mehmed and Ustad Darvish, and with those whose names are written below this writ. We gazed at and observed the locations, which the mentioned trustee had previously reconnoitered to be "doable with eighteen purses [of money]." Thereupon, the mentioned Haji Mehmed and Ustad Darvish and other experts evaluated that the domes of the women's mosque and the hall of Quran-memorizers at the shrine of Imam Huseyn his Holiness as well as the dome and arches of the illustrious mosque at the shrine of Imam Abbas his Holiness need to be repaired anew, that otherwise the upper dome of Imam Abbas's sepulcher and the dome of the women's mosque and the tiles of the sepulcher and other spots need repairs, and estimated that the repairs, restorations, and coatings as a whole "are doable with two thousand thalers, and cannot be done with less than the mentioned amount." They accepted and committed that they themselves do the aforementioned repairs, restorations, and coatings entirely for the aforesaid amount of two thousand thalers. Thereby, what happened has become written down upon request. Penned on May 4, 1670.

\section{Witnesses:}

master Mahmud Efendi the preacher, master Mehmed Efendi the orator, master Khalil Efendi the orator, master Hasbi Efendi the orator, Ahmad Çelebi the former commander, Haji Mehmed b. Abdullah

Document 4 (A.DVN. 64/33)

judicial attestation

$\cdots$

shaikh Mehmed the great-judge of the city of Baghdad [seal:] the preeternal guidance shall be Mehmed's leader

The reason for composing this writ is as follows

For the matter written and expressed in the lines below, an eminent legal session has been convened at the sublime council of the governor of the province of Baghdad the heaven-like, the revered minister, the Asif-signed vizier, the blissful and esteemed Husayn Pasha ... Then, Sayfi b. Ahmad the infantry 
mercenary, Deli Ali the unaffiliated mercenary, and the ones named Araboğlu, Urfalı Mehmed, Ibrahim the Kurd, Ali the Kurd, and Ahmad, who had been previously arrested owing to their banditry and mischief, were brought to court, and the state of affairs of the aforesaid ones were asked from those present at the session. Thereupon, Osman-bey the captain of the left-flank enlistees of the Local Corps, Hasan-bey b. Abdullah, Islam-bey b. Abdullah, Qasim b. Hasan, Kanan b. Abdullah, Mahmud b. Mehmed, and others each bore witness, face-to-face with the aforesaid ones, that "previously, the aforesaid Sayfi, Deli Ali, Araboğlu, Urfalı Mehmed, Ibrahim the Kurd, Ali the Kurd, and Ahmad stood before the caravan headed to visiting Imam Husayn his Holiness, may Sublime God be pleased with him, and when they attacked with the intention of plundering their belongings, we ran across them and observed that they were hijacking; we know that the mentioned Sayfi, Deli Ali, Araboğlu, Urfalı Mehmed, Ibrahim the Kurd, Ali the Kurd, and Ahmad have constantly been hijacking and that they habitually break the law." Thereby, what came to pass has been written down upon request. Penned on February 18, 1672.

[witnesses:]

lecturer Mahmud Efendi the preacher, prayer-leader Mullah Yusuf, Adli Mustafa Efendi, Abdullah Efendi the bookkeeper, scribe Ismail Efendi the treasury logger, Mustafa Agha the summoner, Husayn Çelebi the chief of staff of the Bailiffs, Husayn Çelebi b. Hasan the translator.

\section{Document 5 (iE.EV. 19/2287) grand vizier's summarization to the monarch}

The submission of the powerless servant is as follows, my majestic and wondrous and awesome Padishah!

At Baghdad, the oratorship of the illustrious mosque of Imam Husayn his Holiness, may sublime God be pleased with him, became vacant. Thereby, the copy of the note has been given from the Baghdad treasury, with the request that it be bestowed as alms upon his [the dead former incumbent's] biological child, Abdulfattah. Order and decree are Yours, my majestic, wondrous, and awesome Padishah!

On 9 November 1679

Document 6 (iE. EV. 6/687)

submission, edict

[I: submission] 


\section{He!}

To the Stately Court, the submission of the lowliest servant is as follows. Al-Haj Hasan ibn-i Hamza, who is a beadsman with a daily stipend of ten aspers and an annual [allocation of] sixteen sacks of wheat from the Endowments of the Illustrious Martyria located at Baghdad the heaven-like, has passed away, and [his allowances] have become vacant. Thereby, it is submitted to the Stately Court, with the request that daily five aspers and yearly eight sacks of wheat be kept by the endowment, while daily five aspers and [yearly] eight sacks of wheat be graciously conferred upon your beadsman and this humble submission's initiator Molla Ali bin Molla Sultan, for it is rightfully his.

Nonetheless, order and decree are of the Court of [righteousness].

[II: grand vizier's edict]

AUTHENTIC.

To be accordingly conferred is COMMANDED. 7 August 1685

Document 7 (TSMA.E. 1288/102)

submission, marginal annotation, notification [, and non-extant edict]

[I: submission]

After humbly prostrating myself on the illustrious ground under Your feet my blissful and eminent Sire your Excellency, the submission of the powerless servant is as follows.

Mullah Muhammad b. Mullah Abdurrazzaq, who was sweeper at the shrine of Imam Husayn his Holiness with a daily stipend of fourteen aspers and an annual allowance of ten sacks of wheat from the Endowments of the Illustrious Martyria, passed away, and his position became vacant. Your servant Mullah Khalil b. Mullah Muhammad, his biological son and the initiator of this submission of servitude, is eligible and entitled. The request is hereby submitted that due to the mentioned reason, the position of sweeper be conferred upon him with a daily stipend of seven aspers and an annual allowance of five sacks of wheat, and as his cited stipend and allowance are already recorded in the register of the Illustrious Sanctuaries, the highly illustrious Charter be given. Nonetheless, order and decree are Yours, my Sire his Excellency. Your servant Ali, trustee of the Endowment of the Illustrious Martyria

[II: postscript at the chancery] Logged into the new survey [register]

On 22 October 1687 
[III: annotation from the registry]

Under the oversight of the eminent chief [eunuch] of the Imperial Harem

In accordance with the treasury register of the illustrious Endowment of the Illustrious Martyria, may sublime God be pleased with them, at Baghdad the heaven-like.

Mullah Muhammad b. Mullah Abdurrazzaq, sweeper at the shrine of Imam Husayn his Holiness

Daily:XIV/14

Annually: wheat, sack, $X$

[IV: notification]

It is written and recorded in the register of the State Treasury as explained.

Nonetheless, decree is Yours, my eminent Sire your Excellency.

On 26 March 1688

[tailed signature of the minister of finance]

Document 8 (TSMA.E. 1166/43)

petition and marginal notification

[I: petition]

On 28 May 1688

May my blissful and merciful and eminent Sire live long!

At Baghdad, our father Sayyid Abdulmuttalib, who is from the offspring of Imam Husayn his Holiness, may God be pleased with him, and who is currently the chief of the prophetic descendants in the town of the said Imam, is from the authentic lineage of the afore-mentioned Imam his Holiness. The aforesaid chiefdom is also required to [pass down] among the [prophet's] offspring. Thereby, in the mentioned manner, the stipend of daily twenty aspers, the spinners' market, the weighing-house, one feddan [of land] by River Sayb and one feddan [of land] by River Jubiya, and the exemption of the dye-works are required to [pass down] among the [prophet's] offspring. Our father, who is from among the offspring and who held [these privileges] with the illustrious Charter, has passed away here by the will of sublime God, and the turn to be the holder has transitioned to these servants of Yours. Thereby, my blissful Sire's submission [to the padishah] is requested, regarding the bestowal upon these beadsmen of Yours from the vacancy of our late and deceased father. Nonetheless, decree is Yours, my virile and eminent Sire!

Your beadsman, Sayyid Murtaza

Your beadsman, Sayyid Abd[ullah] 
Your beadsman, Sayyid Muhammad, the current chief

[II: referral by the grand vizierial chief of staff] ITS PLACE [IN THE RECORDS] SHALL BE SEEN.

[III: notification in annotation by the minister of finance]

The following is written and recorded in the new survey register.

It was entered into the new survey register that the mentioned villages, dyeworks, the spinners' market, and the weighing-house be held by the illustrious endowment [without being allotted to persons]. The beadsmanship stipend of daily twenty aspers, the spinners' market, the weighing-house, one feddan [of land] by River Sayb, one feddan [of land] by Jubiya, and the exemption of the dye-works, which were required [to pass down] among to the [prophet's] offspring, were required [to be bestowed] upon Sayyid Abdulmuttalib, who is from among the offspring and who was the chief of the prophetic descendants in the town of Imam Husayn his Holiness, may sublime God be pleased with him. But then, Basralı Ali, the former trustee of the illustrious endowment, gave false notification and had [these items] entered into the new [survey] register. Then, the imperial decree was issued that, so as to be required [to be bestowed] upon those who are chiefs, [these items] be taken out of the new survey [register], registered to their [new] place [among the logs], and explanation be given. Thereby, as explained, [they] were registered to their place and explanation was given.

Order and decree are yours, my Sire your Excellency.

22 July 1688

[signature of the minister of finance]

Document 9 (TMSA.E. 833/25)

petition, submission, marginal annotation, notification, and edict

on 2 July 1688

[I: petition]

\section{$H e !$}

May my blissful and eminent Sire his Excellency live long!

This beadsman of yours is retired with a stipend of daily twenty aspers and an allowance of yearly ten sacks of wheat from the Endowments of the Illustrious Martyria. Now, of my own free will, I step down in favor of Your servant and my own biological son, Sayyid Muhammad. It is requested of the sublime compassion of my blissful and eminent Sire his Excellency that my mentioned stipend 
and allowance be conferred upon my aforesaid son, and as my afore-written stipend is already recorded in the register of the Illustrious Sanctuaries, Your illustrious submission is requested that the illustrious Charter of high glory be issued to his hand. Nonetheless, order and decree are Yours, my Sire.

Your servant Sayyid Abdulmuttalib

[II: submission]

That which is submitted by the beadsman of Your Excellency is as follows.

The above-mentioned Sayyid Abdulmuttalib the petitioner is ill, bedridden, and not able to show up in person. For this reason, in giving up the mentioned allowance in favor of his biological son, Sayyid Muhammad, he made the person named Salim b. Haji Abdullah his deputy. It is submitted to [Your] presence that this has been attested at the law court by witnesses alHaj Muhammad Naqi b. al-Haj Hamza and Shaikh Ahmad b. Haji Suvayd alBaghdadi. Nonetheless, order is [Yours, my] eminent patron of authority.

Your servant Ali the inspector

[Ali the inspector's seal]

[III: referral by the grand vizier's chief of staff] ITS PLACE [IN THE RECORDS] SHALL BE SEEN.

[IV: annotation from the reviewed records]

Under the oversight of the eminent chief [eunuch] of the illustrious Imperial Harem

In accordance with the treasury register of the illustrious Endowments of the Illustrious Martyria (may sublime God be pleased with them) in Baghdad the heaven-like:

Sayyid Abdulmuttalib

retiree, daily $X X$

annually, wheat, $x$ sacks

[v: notification by the minister of finance]

In the register of the State Treasury it is written and recorded that, as explained, the mentioned retirement-pension is held by the petitioner Sayyid Abdulmuttalib with daily twenty aspers and annually ten sacks of wheat allowance. Nonetheless, order and decree are Yours, my Sire Your Excellency. On 16 September 1688

[signature of the finance minister] 
[VI: grand vizier's edict]

[Ali] Efendi the inspector of the Illustrious Sanctuaries! [For you] to see to [this] by judicial means is COMMANDED.

Document 10 (IE.EV. 25/2938)

decree

\section{He!}

Shah Ahmad b. Ibrahim Khan the ever victorious

The revered minister, the grand marshal, the order of the world, the piercingminded administrator of the affairs of the public, the accurate-opinioned perfecter of the matters of all creatures, the paver of the foundation of the state and prosperity, the affirmer of the pillars of bliss and imposingness, the one who is surrounded by the manifold graces of [God] the Sublime King, my vizier Ahmad Pasha who is the governor of Baghdad may sublime God make his imposingness last; and the most-just of the Muslim judges, the foremost of the custodians of the monotheists, the mine of virtue and precision, the bearer of the banners of canon and religion, the inheritor of the knowledges of prophets and apostles, the designee for the abundant grace of God the helper, the master judge of Baghdad may his virtue grow! When my imperial high cypher arrives, it shall be known as follows.

Muhammad Naqiyaddin, who by my majestic Imperial Handwrit is the lifetime trustee of the Endowments of the Illustrious Martyria of Imam Ali and Imam Husayn their Holinesses may God be pleased with them at Baghdad the heaven-like, sent a petition to my Imperial Army, [and reported the following]. The aforesaid endowment was under the oversight of the chief [eunuch] of the Imperial Harem; it was nonchargeable, non-interfereable, and autonomous. Then, the governors of Baghdad, under the name of oversight money and courtly fees, and their retinues, sentries, customs superintendents, and other agents interfered and aggressed uncanonically and unlawfully. And, ... ${ }^{60}$ the aforesaid trusteeship, the previous governor of Baghdad did not let the endowment keep but himself seized and kept two thousand five hundred thalers for himself under the name of oversight money, one thousand thalers for his chief of staff, five hundred thalers for the former treasurer of Baghdad under the name of courtly fees, five hundred thalers for Mehmed the chief of staff, five hundred thalers..., ${ }^{61}$ two hundred and twenty-five thalers for Mustafa, two

6o The paper's fold makes the word here unreadable. 
hundred and ten thalers for the butlers, hundred and eight thalers for his proxy Ali, six hundred thalers for the magistrate of Hilla, and in the years of hundredand-two and hundred-and-three the accruing cash and five hundred sacks of produce from the village of Mavahin, although it is among the annexes of the aforesaid endowment. In total, he took and seized, by oppression and force, seven thousand and four hundred and ten thalers of cash and one thousand sacks of grain from the endowment's wealth without hesitation. When the register of the Accounting of the Sanctuaries of Mecca-Medina was looked at, it was found to be written that the illustrious Endowments of the Martyria of Imam Ali and Imam Husayn and Imam Abbas their Holinesses, may sublime God be pleased with them, located at Baghdad the heaven-like are nonchargeable, non-interfereable, and autonomous in all respects; that governors of Baghdad are not to take one asper or one kernel of oversight money or courtly fees; that retinue aghas, sentry aghas, Hilla's magistrates, the judges, or other superintendents as well as agents are not to intervene or violate; and that it is thus autonomous. From among the Gatekeepers of my Sublime Court ... ${ }^{62}$ may his might grow is appointed and my illustrious order has been issued by the finance department for the legally assigned wealth of the endowment to be collected in its entirety from the aforecited pasha and those mentioned in name. Since [petitioner Muhammad Naqiyaddin the trustee] requested my Imperial Decree that all act accordingly, it is my order to act in accordance with my illustrious order issued by the finance department.

I command that

once [this] arrives, you shall act upon my imposingly mighty decree issued in this regard and my illustrious order given by the finance department; henceforward you shall not consent to or allow its contrary. Know thus, and put trust in the Illustrious Sign.

Written in end of June / beginning of July, 1692

At encampment, on the field of Adrianople

\section{Document 11 (мHM.d. 104, ent. 224)}

\section{Mühimme-abridgement of decree}

Decree to vizier Ahmad Pasha the governor of Baghdad and to the great-judge of Baghdad is as follows.

The trusteeship of the illustrious endowments of Imam Ali may sublime God be pleased with him located at Baghdad, which is from among the endowments under the oversight of ... Nazr Agha ... the current chief of my Imperial

62 name left blank. 
Harem, has been conferred upon ... Muhassil Abdullah Agha. Muhammad Naqi the former trustee claims that he contributed much money [out of his own pocket] to the endowment. Hence, You, who are the afore-cited vizier and the above-cited great-judge, shall see to the accounting of the former trustee in line with the canon, justly inspect and investigate on the spot the registers of income and outgoings, and if it really becomes proven and apparent that he has assets in the endowment, submit the copies of the logs authentically and precisely to my Imperial Court. Thereon ...

So has been written.

In late June / early July, 1692

\section{Document 12 (NMH.d. 5, ent. 86) \\ epistle - official register copy}

[This] is the imperial epistle to the prince of Mecca the Revered.

His princely Highness ... of clean lineage, ... of the Hashemite progeny and prophetic genealogy, ... chief of the House of the Apostle ... the prince of Mecca ... Sharif Sad b. Zayd.... When Our wordwide-obeyed high cypher arrives, it shall be known as follows.

The summarized content of Your letter sent last year with Zulfiqar, ... who was the superintendent of the imperial pilgrimage convoy, has been submitted to the foot of Our majestic blissful throne. Your exertion, striving, and endeavor in the service of the principality of Mecca ... as required by the prince-ship, aristocracy, mark, and nobility within your gorgeous character, and aside from these, your attention to the welfare and comfortable traffic of the joyful pilgrims circumambulating the Forbidden House of God and visiting the Clean Garden of the Master of All-Creatures, and to the orderliness and regularity of the dwellers of the Secure Land of God, which is the most illustrious of the lands on Earth, and of other sections of Hejaz under the jurisdiction of your principality ... have been encompassed by Our majestic universal knowledge. Hence, you have attained Our effective monarchal blessings and positive inclination.... From now on too, Your pleasing works with truthful intentions ... are Our imperial expectation. Our glowing ... grace of monarchy has radiated towards you. Particularly, from our majestic ... robes of honor, one piece of royal robe ... covered with sable ... has been bestowed [upon You]. Thereby, my privy man-at-arms ... has been appointed to the service of its delivery, and Our imperial letter ... has been issued and sent. You shall welcome and wear Our robe of honor with prestigious ... ceremonies, and earn the joy [of receiving it] in accordance with the abundant truthfulness and honesty towards this 
Eternal House ... and ... Exalted Dynasty. Thereafter, You shall seriously strive for the welfare of the residents of the Sanctuaries, protection of the pilgrims and visitors coming from all over the globe to visit the Ancient House [of God], and the patronage of the travelers as well as traders.... As you earlier committed to, You shall take careful action to welcome, escort, and ... guard from the Bedouin bandits the joyful pilgrims from the way-stop of 'Alâ until Medâin Sâlih. And, in particular:

You shall take good care to abide by the rules of peace ... with the sublimely dignified shah of Persia, which have been imperatively firm from the blissful times of Our high-born forefathers and heaven-bound fathers ... until this day, and which have been accepted as well as admitted by him [i.e. to shah], [you shall also take good care] to not impose tolls upon the pilgrims from Persia, to look after them in accordance with my majestic imperial Handwrit that was issued, to pay much attention to the orderliness of the affairs of the public, righteousness of the circumstances of the pilgrims, and all matters delegated to your attention, and to beget nice deeds that will double Our monarchal favor about You. Know thus!

Mid-February 1696

Document 13 (мнм.d. 110, ent. 1259)

Mühimme-abridgement of decree

Decree to the governor of Aleppo, to the governor of Damascus, to the greatjudges of Aleppo and Damascus, and to the judges of ... and ...63 is as follows.

Pilgrims from Persia petitioned. These are pilgrims from Persia; an illustrious Order together with the blissful imperial Handwrit had come out saying that these not be interfered with or harassed in any way at the localities they pass from. Nevertheless, the person known as Haji Mustafa of Tabriz, a dweller of Damascus, came in front of them in Malatya, and took from each of them two golds as they went to the illustrious pilgrimage and one gold as they returned. Aside from this, he also took their money forcibly under the name of "money for the charter and the guide." He [thus] oppressed and violated them, and they request my Imperial Decree that he be prohibited. Therefore, if such uncanonical violation and oppression have happened, [for you] to act upon my previously issued illustrious Decree and to prohibit him ...

So has been written.

In late January, 1698

63 Left blank in the document. 
Document 14 (A.DVN. 257/5 and 257/6)

Petition, Edict, and draft of Decree

[I: submission]

May my blissful Sire his Excellency live long!

The petition of Your servant is as follows. An illustrious decree is requested for your servant Husayn to become the chief packer to the packers of the pilgrims coming from Persia. Nonetheless, decree is Yours, my Sire. Your servant Said, who is deputy to the affairs of Iranian [pilgrim]s

[II: grand vizier's edict] AUthentic. Accordingly, an emphasized decree is Commanded.

[III: imperial decree in draft]

\section{He!}

Decree to Husayn, who has the rank of Master-Gatekeeper of my Sublime Court and who is the deputy for the passage of the Iranian pilgrims, may his glory continue, is as follows.

The pride of the peers Said, who is the deputy for the affairs of the pilgrims of Persia, may his bliss grow, petitioned my Blissful Threshold. He requested my Imperial Decree regarding the person named Husayn's installment and appointment as chief packer upon the packers of the pilgrims and visitors from Persia, who for performing the obligatory pilgrimage departed and set out from the land of Persia to go towards the Illustrious Sanctuaries, and his employment in the said service. Thereby, my highly glorious Decree is issued that all act in the explained manner. I command that ...

In the end of September / beginning of October, 1699

\section{Document 15 (MHM.d. 112, entry 1430)}

\section{Mühimme-abridgement of decree}

Decree to the governor of Erzurum and to the judges of ... and ... and ...64 is as follows.

Mahmud may his might grow from among my privy Halberdiers sent a petition to my Sublime Court. He reports that the service of the provostship of the pilgrims and visitors, who set out from the land of Persia to perform the obligation of pilgrimage and visit the honorable Martyria as well as the blessed shrines, is bestowed upon himself for life with my majestic imperial Handwrit,

64 These district names are left blank in the document. 
that when the afore-cited one wanted to perform the service of provostship, which he is commissioned with, and to take care of the safe and sound traffic of the pilgrims and visitors who, with the purpose of circumambulating the Forbidden House of God and visiting the Clean Garden of the Master of All Creatures his Holiness, departed towards those blessed venues, the Iranians named Ali known as Alakuş and Abdullah stirred up some persons and forestalled his transition to the service of provostship, which he is commissioned with. He requests my Imperial Decree in this regard. Thereby, for nobody to forestall and harass the aforesaid one's transition and crossing to the service that he is commissioned with ...

So has been written.

In late January, 1703

Document 16 (A.DVN. 316/14, anno 1705/1706)

petition and edict

[I: petition]

May my blissful and eminent Sire Your Excellency live long!

This servant of Yours is the chief of the Iranian [pilgrims]. The Iranian pilgrims from the land of Persia are harassed, violated, and wronged each year by the sub-governor of Maarra with exactions of seven-to-eight hundred thalers. Hence it is requested that the unjustified exactions of the mentioned one be forbidden, and the eight hundred thalers that he took this year be returned and handed in to their owners. In this regard, [a] decree [to be] addressed to the governor and the judge of Aleppo is Yours my Sire.

Your servant, Ayub

[II: grand vizier's edict] AUTHENTIC. A decree saying "accordingly, they not be violated" is COMMANDED.

Document 17 (A.DVN. 340/18, anno 1706/1707)

petition and edict

[I: petition]

\section{He!}

May Your Excellency live long my blissful lord, my eminent Sire! The petition of Your servant is as follows. 
This servant of yours is from among the Iranian pilgrims. Upon coming and entering the land of Aleppo, the packers as well as the cameleers and other people of such kind harassed and upset us with uncanonical and unlawful demands of dues, saying "there are dues owed to us" without [showing] any decree. For this reason, it is requested of the sublime compassion of our lord Your Excellency [to give] a sublime decree, saying "to not be thus harassed and upset uncanonically and unlawfully without decrees," addressed to the governor of Aleppo, to the great-judge of Aleppo, and to the chief [appointed] upon us. In this regard, order and decree are Yours, my eminent Sire.

Your servant, Iranian pilgrims

[II: grand vizier's edict] AUTHENTIC.

A decree saying "they should not be harassed with demand of dues against the illustrious canon" is COMMANDED.

Document 18 (MHм.d. 118, ent. 1172)

Mühimme-abridgement of decree

Decree to the great judge and to the proxy-governor or Erzurum is as follows.

Mahmud may his might grow, together with the persons named Ahmad and Mehmed, who are his brothers, came and reported: while these [applicants] were going on the illustrious pilgrimage in the year of eleven twenty and when these [applicants] reached the way-stop of the Hasankeyf district, the person named Ayub, along with the persons named Kutlu the Janissary and Ali the Iranian, who keep company and collaborate with him, descended before these [applicants], seized, chained, and took these [applicants] away to Diyarbekir, imprisoned these [applicants] for about ten days, and usurped by force and unrightfully the money of known amount, properties, and belongings that were alongside these [applicants]; they altogether committed victimization, violation, and transgression; and the said ones are currently in Erzurum. These [applicants] request a decree, that [the case] be taken care of by their [i.e. the wrongdoers'] officers through judicial means, that the money and belongings, which they unrightfully and forcibly seized, be taken back and justice be served in accordance with the signed register issued by the judiciary. Because of this, for [the case] to be seen to on the spot by judiciary means ...

So has been written.

In late January, 1712 
Document 19 (Ev.d. 45167)

endowment register

consisting of imperial handwrit, summarization, joint submission, referral, notification, marginal annotation, petition and scribal note

[I: submission by both ministers of finance]

The submission of Your servants is as follows.

The illustrious Endowments of Imam Ali and Imam Husayn and Imam Abbas their Holiness, may sublime God be pleased with them all, located in the province of Baghdad the heaven-like, had been nearing ruin, because previous trustees had not supported or protected the subjects of the Endowment, and former governors of Baghdad had been eating off the stipends of the stipendiaries and committing violations. Therewith, Ali the previous trustee had made an appeal to the Imperial Court during the auspicious times of the late and deceased Sultan Mehmed Khan his Majesty may his earth be pleasant, saying that the aforesaid Endowment should be annexed to the oversight of the Chief [Eunuch] of the Imperial Harem, registered into the Accountancy of the Sanctuaries of Mecca-Medina, and held in autonomy, that governors of Baghdad not take one asper or grain from the aforesaid Endowment under the name of oversight money or courtly fees, and that officers of welcome and sentry, the overseer, chieftains of the Kasham tribe, magistrates of Hilla, judges, and other superintendents as well as agents had been bringing about the ruin of the aforesaid Endowment with their interferences and aggression. Thereupon, it had been registered into the Accountancy of the Sanctuaries of Mecca-Medina, then an Imperial Handwrit had been issued in the year of ten ninety-four for the Chief [Eunuch] of the Imperial Harem to be the overseer, the old records of the aforesaid Endowment had been given over to the Chancery of the Accountancy of the Sanctuaries of Mecca-Medina from the Chief Accountancy, later a surveyor scribe and a Gatekeeper had been sent and a survey had been made, the survey register had come and been recorded in the year of ninety-nine, and since the year of eleven hundred and two the cited trusteeship had been delegated to one person each year through submission by Chief [Eunuch]s of the Imperial Harem. It is found to be recorded thus in the chanceries. But because the dominance of former governors over the trustees and subjects of the villages of the aforesaid Endowments had led to the weariness of these [trustees and subjects], every three-to-four years one of the eunuchs had come to be independently appointed and sent as trustee, so as not to back away from the annexation and transfer to the oversight of the Chief [Eunuch] of the Imperial Harem. 
However, over the last few years, some Halberdiers gradually arose, and by giving extravagant rewards and courtly fees to a lot of places, took over the cited trusteeship. So much so that from among the Halberdiers a person named Gergerli Husayn became the trustee in the year of eleven eighteen, held it for two years, and unrightfully seized and exacted fines on the crops and belongings of the subjects of the aforesaid Endowment. He could not be turned away from his inappropriate actions arising against God's will in such desirable services, and he passed away thus in Baghdad. The amount and belongings, which he, saying "I am affiliated with the Chief [Eunuch] of the Imperial Harem," gathered up from the Endowment's subjects and from the dwellers of Baghdad and even the governor of Baghdad due to his complete dominance over them, he spent to broaden his influence, to put his affairs in order, and for his arbitrary fancies. This aside, he left behind almost one hundred and fifty purses of cash as well as belongings, which were brought here to his inheritors. Then, since the year of eleven twenty, the ones named Halberdier Haji Osman and Yedekçi Ali arose, and for a few years, received the written nomination for the aforesaid trusteeship for free. The aforesaid Yedekçi Ali roamed the markets and inns, saying "I sell the mentioned trusteeship of the Martyria of Najaf-Karbala," as if selling a state tax-farm to whomever paid the most. He sold it once to the person named Hasan Çorbacı from among the captains of Armorers, once to Ahmad Sayyaf the merchant, then to a Janissary private from the dwellers of Harput, and then to Baghdad's former minister of finance Omar Bey, taking from them fifteen purses of money for each year.

Today, the trustee is again from among the Halberdiers. Since the time that the cited trusteeship had been annexed to the oversight of the Chief [Eunuch] of the Imperial Harem, the trustees, by virtue of being misers, have been filing submissions for the Halberdiers at the service of the Chief Eunuch to get the vacated positions, for which, among the civilian dwellers of Baghdad, persons entitled to hold stipends as well as allowances and to be resident in the required service are already available. In this way, they [i.e. the Halberdier trustees] cause weariness and setbacks to a lot of simple civilians and the cancellation of the Endowment's many services contrary to the conditions of the endower. The trustees, due to their unrefined greed and because they are making here an excessive expenditure of money, sell most of the tax-farms on the spot to Janissaries and other despicable persons. These [tax-farm buyers] haunt and harass the [dwellers], such that the [dwellers], desperate from these molestations and violations, altogether flee to another region. Thus report the unbiased persons living in Baghdad, who have a full grasp [of the matter], and a lot of credible officials of the Sublime State who come in from there [Baghdad], and inform that the removal of this oppression, violation, 
and transgression off the subjects of the illustrious Endowment will bring about bountiful blessings.

When the cited Endowment had formerly been under nobody's oversight, governors and judges of Baghdad had delegated the cited trusteeship to some persons, and governors and trustees had not protected the subjects but harassed and molested them. A notification about this [state of affairs] was then given with a petition. The annexation of the aforesaid Endowment to the oversight of the chief eunuchs was so as to get rid of the corruptions arising from the oversight of the governors of Baghdad and to protect and preserve the subjects of the Endowment. It is frequently reported, however, that upon annexation to the oversight of the chief eunuch of the Harem, the oppression and violation of the Endowment's subjects has become many times greater than before. It is now seen that the earlier trustee's petition was not for getting rid of the corruptions arising from governors of Baghdad but was just an outwardly rightful and artificial initiative organized to have the cited Endowment registered into the [Chancery of the Accountancy of the] Two Sanctuaries. Especially, trustees appointed by the chief eunuch also give a lot of money here under the name of rewards and courtly fees until they have the aforesaid trusteeship delegated to themselves. When they get to the site, they take action to derive their own benefit and profit, and accordingly entitling themselves in their speech with affiliation and assignment of the Majestic Monarchy, they haunt not only the Endowment's subjects but even governors of Baghdad with this false reputation, and gather up several hundred purses of money from the illustrious Endowment's subjects within a couple of years. If it is not tackled and put in order within a while, it is obvious that the subjects will altogether become wretched and the cited Endowment useless in ruins. Transforming it into an agreeable form is important and necessary.

Hereby [it is requested]: for the cited Endowment to be removed from the chief eunuch's oversight; for its registers and documents to be taken away from the Accountancy of the Sanctuaries of Mecca-Medina; for it to be registered in and given over to the Chief Accountancy as before; for governors of Baghdad themselves to personally see to the affairs of the trusteeship every year, by judicial means to make a register of the incurred income and expenditure in line with the endower's conditions at the close of the year, and to send the cited register to the Stately Court; for [the consequent year-end balance sheet] to be summarized and submitted to the Imperial Court through the grand vizier; for the universal imperial gaze to pertain [to this summarization] for nothing else than God's sake; for the awe-inspiring Imperial Handwrit-as blessing and good luck - to be drawn, saying that it should be recorded to its place [in the applicable chancery logs] after its income and expenditures are found 
acceptable by the imperial monarch; for the circumstances of the subjects of the cited Endowment to be personally submitted [by governors of Baghdad] to the Imperial Court and be known by the universal monarch whenever greater and lesser affairs come up; for the cited trusteeship to be delegated to the current governor of Baghdad the esteemed [Eyüplü] Hasan Pasha his Excellency the revered vizier starting from the year of eleven twenty seven and to be assigned once every three years with the condition that their circumstances be seen to as necessary; for the referred vizier to also content himself with what the endower specified in the affairs of the trusteeship; for the courtly fees, welcome officers, sentry officers, customs superintendent, the Kasham tribe's chieftains, magistrates of Hilla, judges, other officials and agents to not interfere or infringe by any means or on any account; for him [Eyüplü Hasan Pasha] to deem this imposing service a means of bliss in both worlds, to act with full justice and equity, to not harass or molest even one individual, to investigate much and pay attention in ascertaining the total income and expenditure in a year by implementing the endower's conditions, to accordingly record, register, submit, and give notification of both the income and the expenditure in this year of twenty-seven, to refrain much from giving in to greed, oppressing and maltreating, scattering, or devastating the Endowment's subjects like the governors of Baghdad who formerly oversaw and like the Halberdiers who later became trustees and others just because "the cited trusteeship became delegated to me," to take great care, pay attention, and make the effort towards the orderliness of the circumstances of [the subjects] and for their welfare, to submit and give notification of the occurring vacancies of stipends on behalf of the locals that are entitled and deserving, to indisputably strive that these [vacant positions] not be given to non-deserving persons just for the sake of an intercession or gratification; for these favorable conditions and stipulations to be taken as principles henceforward for as long as sublime God wills; for [all this] to be registered into the Chief Accountancy; and for the sublime Charter and illustrious Order to be written in the explained manner; order and decree are Yours, my blissful Sire Your Excellency.

[signatures by the chief minister of finance and the second minister of finance]

[II: referral by the grand vizier's chief-of-staff] Its place [in the logs] shall be seen.

[III: grand vizier's edict]

For the esteemed minister of finance ... Efendi to see the earlier and later records, ask those who are informed, and give notification, it is commanded! 
[IV: finance minister's notification]

[IV.1 finance minister's first notification: quoting from archived Imperial Handwrits]

Ibrahim Pasha the vice grand vizier! In line with your summarization, give the decree for the [Endowments of the Martyria of Najaf-Karbala] to be annexed to the Endowments of the Sanctuaries of Mecca-Medina and registered into [the Chancery of] its Accountancy, and for the chief eunuch to be the overseer!

29 August 1683

Ibrahim Pasha the vice grand vizier! Ask, inquire, and neatly submit the truth. Whether or not there is a risk and drawback in being annexed to the Endowments of the Sanctuaries of Mecca-Medina, submit!

[IV.2 finance minister's second notification: quotation from an archived submission of the vice grand vizier]

Submission by the powerless servant is as follows.

The aforesaid endowment is not safe from the oppression of violation. For it to become registered into the oversight of the chief eunuch and the Accountancy of the Sanctuaries of Mecca-Medina, so that no one encroaches, decree is Yours, my majestic and wondrous Monarch.

[IV.3 finance minister's third notification: quoting from an archived petition by the trustee]

Petition by this poor one to the blessed Imperial Court of my majestic, mighty, great, all-merciful Monarch is as follows.

By majestic Imperial Handwrit, this servant of Yours is the trustee of the Endowments of the illustrious Martyria of Najaf-Karbala of Imam Ali (may God make his face revered) his Holiness at Baghdad, and became trustee at the time of Your servant Abdi Pasha as governor of Baghdad. Whereas [before my term] it [the Endowment] had an income of one thousand and four hundred thalers, it has amounted up to ten thousand thalers thanks to the blessedness of the Imperial Handwrit of our majestic monarch. Whereas [under my term] the stipends of its beneficiaries used to be given in full and its kitchen used to operate, it is [now] declining due to violations by Ibrahim Pasha his Excellency the current governor of Baghdad. From the stipends to be given to civilians, he took two thousand thalers for himself and five hundred thalers under the name of courtly fees. Then he handed in to me a register including a seal and 
a decree, for the stipends of the civilians to be given at half. Since he became the pasha [of Baghdad], he took nineteen purses of money from the illustrious Endowment in the years of ten ninety-two, ninety-three, and ninety-four. $\mathrm{He}$ scared this servant of Yours saying "I shall kill you," sent one hundred and fifty horsemen upon me, and by overwhelming force took from this servant of Yours further thirty purses, saying "you had an illustrious Handwrit issued for the pashas not to interfere in the Endowment, now let's see whether your illustrious Handwrit is of any use to you." As I could not save myself by any means, I fled to here by getting a permission with the intention of [going on] the illustrious Pilgrimage. Even the permission to go on the illustrious Pilgrimage, [only] Your servant Shatir Ahmad Agha [could] take [for me]. After I went away, he made my brother-Your servant - the trustee of the trusteeship. What he took from the illustrious Endowment since I left is not known.

For God's and his Messenger's sake; to show mercy to my situation; to cast a gaze on the blissful Imperial Handwrit and the register bearing his own seal, which are in my hand; to save this illustrious Endowment from the aforesaid one's hands; to collect by judicial means the nineteen purses of money he took from the illustrious Endowment and the thirty purses of money he took from this servant of Yours, as Mehmed Efendi the finance minister of Baghdad and Abdullah Efendi the deputy-judge of Belgrade, who are currently here, know that these monies of ours were given; to collect these monies by judicial means; henceforward to annex the aforesaid Endowment to the oversight of Your servant the chief eunuch of the Harem; to register it into the Accountancy of the Sanctuaries of Mecca-Medina; to make the aforesaid Endowment nonchargeable, non-interfereable, and autonomous; to hold and run it as such; henceforward for governors of Baghdad not to take one asper or one grain from the aforesaid Endowment under the name of oversight money or courtly fees; for the welcoming officers, sentry officers, the overseer, chieftains of the Kasham tribe, magistrates of Hilla, judges, other officials, and agents not to interfere or infringe henceforth; for the illustrious Handwrit to be accordingly bestowed; for the Endowment to altogether be revived by my majestic and mighty Monarch; and to get good prayers from the civilians; decree is Yours, my majestic and mighty Monarch.

Your servant Ali

[IV.4 finance minister's fourth notification: quoting from an archived notification]

Ali, who by the stately Imperial Handwrit is the trustee of the illustrious Endowments of the illustrious Martyria of Najaf-Karbala of Imam Ali (may God make his face revered) his Holiness located at Baghdad the heaven-like, 
presented a petition to the Imperial Court while on the field of Belgrade, ..., ${ }^{65}$ and requested grace. Thereby, as the aforesaid Endowment was not safe from the oppression of violation, a summarization was submitted to the feet of the Highest Throne that it be registered into oversight of the chief eunuch of the Imperial Harem and the Accountancy of the Sanctuaries of Mecca-Medina, so that no one encroaches upon it. Thereupon, in accordance with the blissful Imperial Handwrit, which became issued, the highly glorious Decree came out on 4 September 1683, saying "the mentioned Endowment shall be annexed to the oversight of the chief eunuch of the Harem and registered into the Accountancy of the Sanctuaries of Mecca-Medina." As explained, the aforesaid Endowment, in line with the above-mentioned conditions and stipulations, became nonchargable, non-interfereable, and autonomous, annexed to the oversight of the chief eunuch of the Harem, and registered into the Accountancy of the Sanctuaries of Mecca-Medina, as per the highly glorious Decree that was issued in accordance with the incoming blissful Imperial Handwrit, and it came under the oversight of the chief eunuch. Yusuf Agha (may his sublimity continue), who is the chief eunuch of the Imperial Harem and trustee of the Endowments of the Sanctuaries of Mecca-Medina, gave a submission to the Imperial Army and reported the request: that it be conferred for life to be held from 7 September 1683 onwards and that the highly glorious Charter be given anew, because the mentioned trusteeship of the Endowments of the Najaf-Karbala Martyria of Imam Ali [and Husayn] his Holiness Ali (may God make his face revered) was held by the cited Ali with a fixed stipend and by Imperial Handwrit of bliss, also because he served the illustrious Endowment righteously and worked hard for it. A Decree of high glory came out to confer accordingly. The trusteeship of the aforesaid Endowment, together with its fixed stipend, became conferred for life, to be held from 7 September 1683 onwards. A written note is given for the [issuance of a] renewed Charter of high glory for the illustrious Endowment to be nonchargable, non-interfereable, and autonomous, with the condition that the referred Ali (may his might increase) hold it in the same manner as former trustees and collect for the illustrious Endowment the accruing greater as well as lesser amounts of produce and tolls in the same manner as former trustees; for its accounting to be seen to in the next year; for governors of Baghdad not to interfere or intervene under the name of oversight money or courtly fees; for welcome officers, sentry officers, overseers, chieftains of the Kasham tribe, magistrates of Hilla, judges, other

65 Here is a lengthy quotation from the said petition by Ali, which I left out so as not to repeat, because it is already quoted in the entry above. 
officials, and agents to henceforward not interfere or intervene; and for the Endowment's trustee to hold and run it autonomously.

Thus is found to be written in [the logs of the Chancery of] the Accountancy of the Two illustrious Sancturies.

8 September 1683

[IV.5 finance minister's fifth notification: quoting from another archived notification]

Yusuf Agha, who is the overseer of the aforesaid Endowments, sent a submission to the Imperial Council. Under his oversight, located in the province of Baghdad the heaven-like, within the illustrious Endowments of Imam Ali and Imam Husayn and Imam Abbas their Holiness (may sublime God be pleased with them all), from the river of Euphrates up to the town of Imam Ali his Holiness, the villages, croplands, orchards, gardens, date palms, and other items that are endowed by the deceased Sultan Suleiman Khan (may his earth be pleasant) within the towns of Imam Ali, of Imam Husayn, the townships of Hilla, Mahrud, Mandanjin, Shahriban, Had, and their subordinated units, had previously been surveyed and worked into the register in the year of nine hundred eighty-three, but since that time until now, have not been surveyed [anew]. Some persons turned most parcels of the Endowment into their private property and made these [parcels] required [to be bestowed] upon their selves, saying "these are made required for us" whereas this is not in the old survey registers, and thus seized and held [these alienated properties] against the register and contrary to the conditions of the endower. The illustrious Endowment altogether suffered, while many of its parts became concealed, disrupted, and upset. [Yusuf Agha] reported thus, and requested that an emphatic illustrious Order of high glory addressed to the revered vizier his Excellency guarding Baghdad and the great-judge Efendi of Baghdad be given; that the villages, croplands, orchards, gardens, date palms, shops, dye-works, butcheries, weighhouse, spinners' market, bathhouse, state as well as private assets, which in accordance with the old survey register belong to the Endowments of Imam Ali and Imam Husayn and Imam Abbas their Holiness and are located within the borders of the towns of Imam Ali, Imam Husayn, the townships of Hilla, Mahrud, Mandaljin, Shahriban, Had, Kebçe, and their subordinated units, as well as the soup-kitchens, roofed [buildings], and whatever greater and lesser innovated within the borders of the Endowment after the [original] survey, be surveyed [anew] and worked into the registers; that nothing big or small from the croplands, orchards, date palms, soup-kitchens, and roofed buildings of the aforesaid Endowment be hidden or remain unregistered; that all these 
be surveyed well and worked into the registers; that Mehmed Kalfa a senior clerk of the Accountancy of the Sanctuaries of Mecca-Medina be appointed as surveyor and Mehmed from among the Gatekeepers of the Sublime Court as commissary; that the aforesaid Endowment be surveyed and registered with full discipline and care by means of these two and Ali Agha the trustee of the Endowment; that no nonaffiliated person infringe, forestall, or harass their surveying; and that a good orderliness be instituted. In accordance with the submission by the Endowment's overseer and the issued Sublime Decree saying "a decree shall be accordingly given," an illustrious Order was given on 10 March 1686 that it be surveyed anew as explained.

1 November 1686

This too is found to be written [in the logs].

[Iv.6 finance minister's sixth notification: quoting from a third archived notification]

The survey register of the aforesaid surveyor came in, and became processed. It has been recorded into the State Registry. In accordance with the sublime Decree dated with the year of ten ninety-nine, it is being kept at the Accountancy of the Sanctuaries of Mecca-Medina for its sealed copy to be taken as authoritative.

Whereas the aforesaid Ali held the aforesaid trusteeship up until the year of eleven hundred and two, in the aforesaid year he was removed and it was conferred upon somebody else. Since that date, it has been conferred by the Endowment's overseer upon one other person each year. To hold it from the beginning of March of eleven twenty-six onwards, it has been conferred upon the person named Haji Hasan with a sublime Decree in accordance with the submission by blissful Mehmed Agha the current overseer of the Endowment and the chief eunuch of the Imperial Harem.

Thus is written and recorded in the [chancery logs of the] Accountancy of the Sanctuaries of Mecca-Medina.

[v: renewed referral by the grand vizier's chief of staff] In what manner were the former records of the cited Endowment? It [shall be] annotated in detail by the Registry.

[vi: annotation by the State Registry] in the county of $[$ Bagh $]$ dad

from the Endowments of Imam Ali, Imam Husayn, and Imam Abbas their Holiness (may sublime God be pleased with them) 
illustrious Martyrdom of Imam Ali his Holiness (may God make his face revered) per person

revenue from the earnings of the rent of the old bathhouse, annually: 19o thaler

the sum including other items, annually, 2582 thaler in 120 from the Endowments

[VII: second renewed referral by the grand vizier's chief of staff] Its former records shall be annotated by the [Chancery of the] Lesser Endowments [Accountancy].

[VIII: annotation by the Chancery of the Lesser Endowments Accountacy]

There is no record of its at the Lesser Endowments Accountancy. Decree is Yours, my Sire Your Excellency.

19 September 1714

[signature by the Accountant of the Lesser Endowments Chancery]

[Ix: third renewed referral by the grand vizier's chief of staff] It shall be annotated by the Accountancy of Anatolia. It shall be annotated by the Chief Accountancy.

[x: annotation by the Chancery of the Chief Accountancy]

Whereas the Endowments of the Martyria of Najaf-Karbala located in [the province of] Baghdad were registered in the Chief Accountancy, its registers were given over to the Chancery of the Accountancy of the Sanctuaries of Mecca-Medina by a sublime Decree in the year of ten ninety-four, so that it comes under the oversight of the chief eunuch of the Harem. Decree is Yours, my blissful Sire Your Excellency.

20 September 1714

[signature by the Chief Accountant]

[XI: fourth renewed referral by the grand vizier's chief of staff] Under whose oversight was it? Shall be annotated by the Chief Accountancy.

[XII: second annotation by the Chancery of the Chief Accountancy]

The following is written in the register: it was previously under nobody's oversight. Its trusteeship was being conferred through a submission by the governor 
and the judge of Baghdad, and also through a petition. Decree is Yours, my blissful Sire Your Excellency.

20 September 1714

[signature by the Chief Accountant]

[XIII: summarization by the grand vizier]

My majestic, gracious, wondrous, mighty Monarch! Submission by the powerless servant is as follows.

[Above] is the detailed submission by Your servant the finance minister Efendi, concerning the Endowment and trusteeship of the Martyria of NajafKarbala located in [the province of] Baghdad. When You majestically please to gaze upon it, as mentioned in the afore-cited summarization: regarding the afore-cited trusteeship's removal from the Chancery of the Sanctuaries of Mecca-Medina, registration back into the Chancery of the Chief Accountancy as before, delegation together with its conditions to governors of Baghdad, therefore the bestowal of the blessed Imperial Handwrit of grace, and the revival of the aforesaid Endowments, order and decree are Yours, my majestic, gracious, imposing, awesome master the Monarch.

[XIV: imperial handwrit]

For the prosperity of the illustrious Endowment and the welfare of the civilians, the aforesaid Endowment shall be removed from the oversight of the chief eunuchs, its registration at the Accountancy of the Sanctuaries of Mecca-Medina shall be cancelled, and it shall be registered into the Chief Accountancy as in the past! And henceforward, all shall act in accordance with these conditions and regulation, and refrain from [doing] the contrary!

[Xv: edict by the grand vizier]

Authentic.

It is COMMANDED

that it be removed from oversight, that its registration at the Accountancy of the Sanctuaries of Mecca-Medina be cancelled, that its registers be taken, logged in and given over to the Chief Accountancy as in the past, that these very conditions be taken as authoritative henceforward, and that a Charter be given out, in accordance with the issued majestic Imperial Handwrit.

6 October 1714 
[XVI: last referral by the grand vizier's chief of staff] A memorandum shall be given to the Chancery of the Sanctuaries of

Mecca-Medina.

[XVII: note by a scribe] A memorandum has been given to the Accountancy of the Sanctuaries of Mecca-Medina. 15 October 1714

Document 2O (EV.HMH.d. 02584) accounting register

Draft [register] of the Two Illustrious Martyria

from the dues of the year September 1721-August 1722

$[\mathrm{I}]$

ACCOUNTING of

the revenues and outgoings of the Illustrious Endowments of the Two Martyria in [the Province of] Baghdad the heaven-like, from the bond of the revered vizier and grand marshal Hasan Pasha his Eminency — may God facilitate what he wishes - currently the guardian of Baghdad;

the beginning of September of the year 1721 until the conclusion of that [full] year:

CAPITAL STOCK:

within the full year, with the remainder of the accounting from the past year: $17155^{1 / 2}$ lion thaler

from the MONEY of

coffers of the Endowment's receivership, from the Chief Accounting [Chancery], from the September of 1721, remaining and currently presented in the accounting:

$2223 / 4$ lion thalers

from REVENUES of

the aforesaid:

$1693^{3} 3 / 4$ lion thalers 
FROM

rents and tolls of the aforesaid:

11099 1/2 lion thalers

from REVENUE of

tax-farms of the Endowment in the town Imam Ali his Holiness may God be pleased with him, from the beginning of the September of the year 1721:

5375 thalers per annum

THEREFROM:

diminished with the decrease in visitors from Persia

$-1251 \frac{1}{2}$ thalers

$=4123 \frac{1}{2}$ thalers remainder offset

from REVENUE of

tolls of graves and vows at the shrine of the cited Imam his Eminency within the mentioned dates:

35 o thalers per annum

from REVENUE of

tolls of graves at the shrine of Imam Husayn his Holiness, may God be pleased with him, within the mentioned dates:

125 thalers per annum

from REVENUE of

rent of the Endowment's inn at the town of the cited Imam his Holiness within the mentioned dates:

295 o thalers per annum - minus 1000 thalers $=$ remainder $195^{\circ}$

from REVENUE of

half rent of the Endowment's dyeworks in the town of the cited Imam his Holiness within the mentioned dates:

525 thalers per annum

from REVENUE of

rent of the Endowment's press-works in the town of the cited Imam his Holiness within the mentioned dates:

105 o thalers per annum 
from REVENUE of rent of the Endowment's butchery in the town of the cited Imam his Holiness within the mentioned dates:

1000 thalers per annum

from REVENUE of rent of the rosary-makers in the town of the cited Imam his Holiness within the mentioned dates:

1460 thalers per annum - minus $1000=$ remainder 460

from REVENUE of rent of the coffin ? in the town of the cited Imam his Holiness within the mentioned dates:

250 thalers per annum - minus $200=$ remainder 50

from REVENUE of rent of the Stony Market in the town of the cited Holiness within the mentioned dates:

85 thalers per annum

from REVENUE of bridal toll in the town of the cited Imam his Holiness within the mentioned dates:

go thalers per annum

from REVENUE of foodstuff of the guilds' trustee in the mentioned town: 400 thalers per annum

from REVENUE of rent of the prefecture in the mentioned town within the mentioned dates:

100 thalers per annum

from REVENUE of the field-watch of the cattle pastures in the mentioned town: 112 thalers per annum

from REVENUE of rent of shops and houses in the mentioned town: $2201 / 2$ thalers per annum 
from REVENUE of rent of the shops and houses of the town of Hilla within the $\mathrm{m}$ [entioned] dates:

11 thalers per annum

from REVENUE of rent of the shops and the mill in the city of Aleppo within the mentioned dates:

$37^{\frac{1}{2}}$ thalers per annum

from REVENUE of

rent of the bathhouse and the date palm[s] and the farm of Mandaljin:

40 thalers per annum

from REVENUE of

chieftainship of the villages of the Endowment in the town of Hilla within the $\mathrm{m}$ [entioned] dates:

6o thalers per annum

from REVENUE of

holiday and festival tolls from the villages of the Endowment in the town of Hilla within the mentioned dates:

9o thalers per annum

from REVENUE of

lump-sums and crops and etc.

$4963^{1 / 2}$ thaler per annum

from REVENUE of

diggers, fee of one-fifth, in the villages of the town of Imam Husayn his Holiness, may God be pleased with him, from the beginning of September of the year 1721:

655 thalers per annum

from REVENUE of

rent of fish around the town of the cited Imam his Holiness within the mentioned dates:

100 thalers per annum 
from REVENUE of money of the digging fee of the Endowment's villages in Hilla within the $\mathrm{m}$ [entioned] dates:

25 o thalers per annum

from REVENUE of

of River Mahavil-ayn within the mentioned dates:

$199 \frac{1}{1} 2$ thalers per annum

from REVENUE of

rent of the ? ? along with date palm[s] by River Umran within the mentioned dates:

$267^{1 / 2}$ thalers per annum

from REVENUE of

estates of Iranians within the mentioned dates:

25 thalers per annum

from REVENUE of

money of glad-tidings of the Corps within the mentioned dates: 10 thalers per annum

from REVENUE of the per-sack lump-sum of the Husayniya rivers within the mentioned dates:

1134 thalers per annum

from REVENUE of the per-sack lump-sum of the villages of the Endowment in Hilla within the $\mathrm{m}$ [entioned] dates:

265 thalers per annum

from REVENUE of appraisal of the crops of the orchards in the town of Imam Husayn his Holiness:

200 thalers per annum

from REVENUE of men's capitation in the farms of the villages of Husayniya within the m[entioned] dates: 225 thalers per annum 
from REVENUE of date palm in the town of Shafâte within the mentioned dates: 40 thalers per annum

from REVENUE of

date palm of the villages of the Illustrious Endowment in the town of Hilla within the $\mathrm{m}$ [entioned] dates:

1540 thalers per annum

from REVENUE of

rent of the new shops and the coffee-house within the mentioned dates:

$33^{1 / 2}$ thalers per annum

from INCOME of

rivers of Husayniya in the Endowment villages in Hilla:

1525 sacks of wheat and barley, with Hillan scale

from PRICE of

wheat and barley of Husayniya:

1155 sacks

955 sacks of wheat

200 sacks of barley

from the ENDOWMENT'S VILLAGES

wheat and barley in Hilla:

370 sacks

215 sacks of wheat

155 bags of barley

MINUS

spent for allocation receivers and the pensioners and etc.

$1005^{1 / 2}$ pieces of sack of wheat and barley

446 thalers / 96o sacks of wheat

423 thalers / $45^{\frac{1}{2} 2}$ sacks of barley

REMAINDER

sold, in Hünkârî calculation

+446 thalers $=105$ sacks of wheat, $4^{1 / 4}$ each

$+423^{1 / 2}$ thalers $=154^{1 / 2}$ sacks of barley, $2^{3 / 4}$ each 


$$
=869^{1 / 2} \text { thalers }=259^{1 / 2} \text { sacks of wheat and barley }
$$

TAKEN OUT OF IT

12710 lion thalers

\section{STIPENDS of}

servants of the Endowment and the pensioners of the beadsmen and etc. at the shrine of Imam Ali and Imam Husayn and Imam Abbas their Holinesses, may sublime God be pleased with them all:

7203 thalers per annum $=3602$ [aspers per] day

per [daily] asper: 2 thalers per annum

from the OUTGOINGS of

along with the necessities of the aforesaid ones:

5506 pieces of lion thaler

FROM

other outgoings:

3971 pieces of lion thaler

TOWARDS

expenditures of the soup-kitchen of the shrine of Imam Ali his Holiness, may sublime God be pleased with him:

199 thalers per annum

TOWARDS

expenditures of the soup-kitchen of the shrine of Imam Husayn his Holiness, may sublime God be pleased with him:

333 thalers per annum

TOWARDS

cost of robes-of-honor for tax-farmers along with the elders of the guilds, as per the ancient custom:

140 thalers per annum

TOWARDS

cost of beeswax for the shrine of Imam Ali his Holiness, may God be pleased [with him]:

135 thalers per annum 
TOWARDS

cost of beeswax for the shrine of Imam Husayn his Holiness, may sublime God be pleased with him:

135 thalers

TOWARDS

expenditures of the water-wheel at the shrine of Imam Ali his Holiness, may sublime God be pleased with him:

75 thalers per annum

TOWARDS

cost of candle for the Baraa Night and prayer rug for the pulpit of the illustrious mosque of Imam Ali his Holiness:

$13^{1 / 2}$ thaler

TOWARDS

cost of beeswax of the Baraa Night for the illustrious mosque of Imam Husayn his Holiness:

$7^{1 / 2}$ thalers

TOWARDS

cost of mat for the illustrious mosque and necessities of the shrine of Imam Husayn his Holiness:

$72 \frac{1}{2}$ thalers

TOWARDS

wage of the watchmen of the granary in the town of Imam Husayn his Holiness:

12 thalers

TOWARDS

cost of sesame oil for the lodge of the Bektashis at Baghdad and Hilla:

28 thalers

TOWARDS

cost of sesame oil for the shrine of Imam Husayn his Holiness, may God be pleased with him:

$48 \frac{1}{2}$ thalers 
TOWARDS

cost of lamp and cotton and string for the mosque of Imam Husayn his Holiness:

$7^{1 / 2}$ thalers

TOWARDS

festival bonus of the prayer-callers of the illustrious mosque of Imam Husayn his Holiness, as per the ancient custom:

17 thalers

TOWARDS

festival bonus of the master preacher, as per the ancient custom:

10 thalers per annum

TOWARDS

rent of the granary in the town of Imam Husayn his Holiness:

7 thalers

TOWARDS

cost of prayer rug for the pulpit of the illustrious mosque of Imam Husayn his Holiness, may sublime God be pleased with him:

8 thalers

TOWARDS

cost of lamps and cotton and string for the illustrious mosque of Imam Ali his Holiness, may sublime God be pleased:

9 thalers

TOWARDS

cost of robes-of-honor for the tax-farmers of the villages of Azar as per:

200 thalers

TOWARDS

digging fee of River Husayniya and the robes-of-honor of the contractors as per:

250 thalers 
TOWARDS

cost of tin for the cauldron of the state's soup-kitchen, spent:

$4^{1 / 2}$ thalers

TOWARDS

expenditures of the deputy of the trustee of the Endowment, as per the ancient custom:

1959 thalers per annum

TOWARDS

signature fee of the great-judge master inspector, and the coffers fee, and the chancery fee, as per the ancient custom:

100 thalers

TOWARDS

fee of the accounting register of the Endowment, as per the ancient custom:

200 thalers per annum

\section{from RESTORATIONS}

mentioned:

1535 lion thalers

TOWARDS

fee for repairing the granary, spent within the mentioned dates: 35 thalers

TOWARDS

fee for repairing the bathhouse in the town of Imam Ali his Holiness, may God be pleased:

6 oo thalers

TOWARDS

fee for repairing the dome of Imam Ali his Holiness, may God be pleased: 3 oo thalers

TOWARDS

fee for repairing the new inn, within the mentioned dates:

6 oo thalers 


$$
\text { [III] }
$$

This is the register in which the cash and grain income and expenditures of the Endowments of the Two Illustrious Martyria from the September of the year 1721 up to the conclusion [of the full year] are declared.

STOCK

from the INCOME of

tax-farms of Imam Ali his Holiness and accruing therefrom within the mentioned year:

$5375^{\text {thalers }}$ - minus $125^{1 / 2}$ decline $=4123^{1 / 2}$

toll for graves and vows at the shrine of the cited Imam: 35 o thaler

toll for vows at the shrine of Imam Husayn his Holiness: 220 thaler

graves at the shrine of Imam Husayn his Holiness: 125 thaler

rent of the inn at the town of Imam Husayn his Holiness: 295 o thalers - minus 1000 decline $=195^{\circ}$

half rent of the dye-works of Imam Husayn his Holiness: 525 thalers

rent of the press-works of Imam Husayn his Holiness: 1050 thalers

rent of the butchery in the town of Imam Husayn his Holiness: 1000 thalers

rent of the rosary-makers in the town of Imam Husayn his Holiness: 1460 thalers - minus 1000 decline $=460$

rent of ? shroud in the town of Imam Husayn his Holiness: 250 thalers - minus 200 decline $=5^{\circ}$ 
rent of the Stony Market in the town of Imam Husayn his Holiness: 85 thalers

rent of the bridal toll in the mentioned town:

9o thalers

foodstuff of the trustee of the guilds in the mentioned town: 400 thalers

rent of the prefecture in the mentioned town:

100 thalers

field-watch of the cattle pasture of the mentioned town: 112 thalers

money of chieftainship of the villages of the Illustrious Endowment located in Hilla:

6o thalers

rent of shops and houses within the mentioned year:

$220^{1 / 2}$ thalers

holiday and festival money of the villages of the Illustrious Endowment located in Hilla:

9o thalers

rent of the shops and houses in the town of Hilla:

11 thalers

rent of the inn and the shops along with the mill:

$37^{1 / 2}$ thalers

rent of the bathhouse and the date palm and the farm of Mandaljin: 40 thalers

revenue of digging, one-fifth, around Imam Husayn his Holiness: 655 thalers

rent of fish around the town of Imam Husayn his Holiness: 100 thalers 
money of the digging charge of the villages of the Illustrious Endowment located in Hilla:

250 thalers

revenue of River Mahavil-ayn within the full year:

$199^{1 / 2}$ thalers

revenue of the township ? along with date palm of River Umran in Mahrud:

$267^{1 / 2}$ thalers

estates of Iranians:

25 thalers

glad-tidings of the Corps within the full year:

1o thaler

revenue of the per-sack lump-sum of the Husayniya rivers:

1153 thalers

revenue of the per-sack lump-sum of the villages of the Illustrious Endowment located in Hilla:

265 thalers

revenue of the appraisal of the crops of the orchards in the town of Imam Husayn his Holiness:

200 thalers

revenue of date palms in the town of Shafata:

40 thalers

revenue of men's capitation in the villages and farms of Husayniya: 225 thaler

revenue of date palm of the Illustrious Endowment in the town of Hilla: 1540 thaler

rent of the new shops and the coffee-house:

$33^{1 / 2}$ thalers 
Income of grain, with Hillan scale:

+955 wheat +200 barley, rivers of Husayniya

+215 wheat +155 barley, villages of the Illustrious Endowment in Hilla

$=1170$ wheat +355 barley

- minus 96o wheat-minus 45 barley, allocation receivers

= remainder: 210 wheat, in Hünkârî calculation 105, apiece price 4 1/4 lions +310 barley, in Hünkâri calculation 154 1⁄2, apiece price 2 3\%4 lions

lion thalers:

wheat $446^{1 / 4}+$ barley $423^{1 / 2}$

$=8693 / 4$

SUM

$1693^{3 / 4}$ thalers

$[\mathrm{IV}]$

CANONIZED EXPENDITURES OF THE ILLUSTRIOUS ENDOWMENT, AND EMERGENCES

TOWARDS

salaries of the beadsmen and pensioners and servants of the enlightened shrine of Imam Ali his Holiness and Imam Husayn his Holiness and Imam Abbas his Holiness, may sublime God be pleased with them all: [per] day: 3602 [akçe]; apiece 2 lions

in thaler calculation:

7204

TOWARDS

soup-kitchen of the shrine of Imam Ali his Holiness, may sublime God be pleased with him:

199 thalers

TOWARDS

soup-kitchen of the shrine of Imam Husayn his Holiness:

333 thalers 
TOWARDS

cost of robes-of-honor for tax-farmers and elders of the guilds as per the ancient custom:

140 thalers

TOWARDS

cost of beeswax for the shrine of Imam Ali his Holiness

135 thalers

TOWARDS

expenditures of the water-wheel at the shrine of Imam Ali his Holiness,

G. p.

75 thalers

TOWARDS

beeswax for the shrine of Imam Husayn his Holiness, G. p.

135 thalers

TOWADS

candle for the Baraa night and cost of prayer rug for the pulpit of the illustrious mosque of Imam Ali his Holiness, G. p.

$13^{1 / 2}$ thalers

TOWARDS

candle for the Baraa night for the illustrious mosque of Imam Husayn his Holiness:

$7^{1 / 2}$ thalers

TOWARDS

cost of mat for the illustrious mosque and necessities of Imam Husayn his Holiness and Imam Abbas:

$72 \frac{1}{2}$ thalers

TOWARDS

wage of the watchmen of the granary in the town of Imam Husayn his Holiness, G. p.

12 thalers 
TOWARDS

cost of sesame oil for the lodge of the Bektashis in Baghdad and Hilla: 28 thalers

TOWARDS

cost of sesame oil for the shrine of Imam Husayn his Holiness, G. p. $48 \frac{1}{2}$ thalers

TOWARDS

cost of lamps and cotton and string for the illustrious mosque of Imam Husayn his Holiness:

$7^{1 / 2}$ thalers

TOWARDS

festival bonus of prayer-callers of the illustrious mosque of Imam Husayn his Holiness:

17 thalers

TOWARDS

festival bonus of the master preacher as per the custom:

10 thalers

TOWARDS

rent of grain [i.e. granary]

7 thalers

TOWARDS

cost of prayer rugs for the pulpit of the illustrious mosque of Imam Husayn his Holiness:

8 thalers

TOWARDS

repair of the granary:

35 thalers

TOWARDS

cost of lamps and cotton and string for the illustrious mosque of Imam Ali his Holiness, G. p.

9 thalers 
TOWARDS

cost of robes-of-honor for the tax-farmers of date palm of Azar 200 thalers

TOWARDS

digging of the Husaynniya river and the robes-of-honor of the contractors: 25 o thalers

TOWARDS

expenditures of the deputy of the trustee within the full year: 1959 thalers

TOWARDS

cost of tin for the cauldron of the soup-kitchen:

$4^{1 / 2}$ thalers

TOWARDS

charge of the surre:

1000 thalers

TOWARDS

surplus of the Illustrious Endowment:

3000 thalers

TOWARDS

accounting fee:

3 oo thalers

TOWARDS

restoration of the bathhouse in the town of Imam Ali his Holiness, G. p. 6 oo thalers

TOWARDS

restoration of the dome of Imam Ali his Holiness, G. p. 3 oo thalers

TOWARDS

restoration of the new inn:

6 oo thalers 
Submission by this servitor of Yours is as follows.

As declared in this register: some tax-farms of the Endowments of the Two Illustrious Martyria are leased out with deductions because of the decline in visitors from Iran. Its capital stock and its current deduction are exactly written out. With the grain prices of the mentioned year, it has in total sixteen thousand, nine hundred and thirty two and a half and a quarter thalers of income, and sixteen thousand, seven hundred and ten thalers of expenditure. After the mentioned expenditure is subtracted from the speficied income, the net remainder of two-hundred twenty-two and a half and a quarter thalers are in the coffers, and the mentioned amount is dispatched. It is requested that upon its arrival, it be received, this very register be logged into its place, and a receipt copy be bestowed upon this servitor of Yours as voucher. In that regard, order and decree is of the Just Court. Written on $10 \mathrm{~J}$ [anuary] 1723

your servitor:

Hasan, currently the guardian of Baghdad [seal]

REMAINDER:

$4445^{3 / 4}$ lion thalers

REMAINDER THEREFROM:

$42223 / 4$ lion thalers

TOWARDS

payment of the money of the surre charge, delivered to the Treasury of the Two Illustrious Sanctuaries, by Emin Mehmed Agha the agent-atCourt of the cited vizier his Excellency, September 1721:

1000 thalers per annum

TOWARDS

payment of the money of the surplus of the Endowment, delivered to the Treasury of the Two Illustrious Sanctuaries, by the mentioned Emin Mehmed Agha, September of the same year:

3000 thalers per annum 
TOWARDS

payment of the money in the coffers of the Endowment, receivership, from the Chief Accountancy, September 1721, delivered to the $\mathrm{m}$ [entioned] Treasury by the $\mathrm{m}$ [entioned]:

$222 \frac{1}{2}$ thalers

NET REMAINDER

$2223 / 4$ lion thalers

\section{Document 21 (Münşeat-ı Nazmizâde Murtazâ, $38 b-39 b$ ) \\ Type: letter, in fragment and verbatim copy, from the Ottoman governor of Baghdad to the grand vizier of Safavid Iran}

... the eminent, highly-glorious xan of elevated dignity, ... trust of the Iranian state! After presenting to Your lofty assembly ... honest and meaningful prayers, ... which boost the council of friendship and fellowship, what the pen depicts is as follows. This year, ... Beyg, the model of his equals and peers, became appointed the pilgrimage commander for the service of facilitating the inbound and outbound journeys as well as the protection ... of the salvationbound pilgrims, who intend to go on the pilgrimage to the Forbidden House of God and visit the Garden of the Master of all creation ... over the Baghdad road ... and who depart for this righteous path. [This] letter is penned ... for the permit to be given to the joyful pilgrims from ... Iran, who mean to circumambulate the Ancient House and intend to visit the Garden ... this year, and for the cropland of the hopes of the Muslims to be soaked and refreshed by Your clouds of generosity. When, God-willing, [this letter] attains the honor to be read by You, it is expected that You ... please to not spare Your sympathy ... from the afore-said servant of Yours and that You please to spend all efforts and take good, comprehensive care to send off the ... pilgrims with complete hopes, caressing, ... and utmost encouragement. It is not a secret ... that the expenditure of Your dear attention in this regard will bring about good renown [for You]. God willing, it is for sure that I the well-wisher of Yours will also expend all care ... and attention ... to support and uphold them ... in every way. Aside from these [matters], it is free from any doubt that opening the highway of pilgrims and visitors and preparing the tools to obtain the expectations of the Muslims [will] stir the chain of affection, cause the reinforcement of the firm peace,... and occasion the welfare of all mankind ... 


\author{
Transcription \\ Belge 1 (iE. EV. 6/675) \\ Arz, Derkenar, Buyrultu
}

Dergâh-ı felek-medâr ve bârgâh-ı gerdûn-iktidâr türâbına arz-ı bende-i bîmikdâr budur ki; hâliyâ Bağdad'da vâkı Meşhedeynü'ş-Şerîfeyn evkafı mütevellisi olan bâ’is-i arz-ı ubûdiyet Seyyid Zeyd bendeleri mukaddem ve müstakim cemî‘-i ehl-i vezâif kendinden râzı ve şükrân üzere, evkaf-ı mezbûrenin i’mârına sa'y olmakla, tevliyet-i mezbûre hâliyâ üzerinde olup, geri mukarrer olunup yedine berât-ı şerîf-i âlişân sadaka ve ihsân buyurulmak ricâsıyla Der-i Devlet-medâra arz olundu. Baki ferman Der-i Ma'delet-unvânındır. bende İbrâhim

MAHALLİ GÖRÜLE.

\title{
Ber-mûcib-i defter-i Hazîne:
}

Tevliyet-i hazret-i İmâm Hüseyin radi allahu anh dervilayet-i Bă̆dâd, der uhde-i Seyyid Zeyd, ber mûceb-i arzıhâl-i Seyyid Abbas nâzır-ı vakf-ı mezbûre tezkire-i berât dâde fî 17 Muharrem se[ne] 1076 ve bâ sûret-i ruus-i hümâyun el-vâkı fî 13 Muharrem se[ne]-iminhu.

Tevliyet-i mezbûre vech-i meşrûh üzere mûmâileyhin üzerinde olduğu defterde mastûrdur. Ferman saadetlü sultânım hazretlerinindir.

fî $28 \mathrm{Zi}$ [lkade], se[ne] 1077

SAHH. MÛCEBINCE İBKA VÜ MUKARRER KILINMAK BUYURULDU! fî 29 Zi[lkade] se[ne 10]77

\author{
Belge 2 (A. DVN. 54/11) \\ Arz, Derkenar, Buyrultu
}

$H \hat{u}$ !

Dergâh-ı felek-medâr u bârgâh-ı gerdûn-iktidâr lâzâle âliyeten ilâyevmü’-karâr türâbına arz-ı bende-i bî-mikdâr budur ki:

İşbu râfic-i arz-ı ubûdiyet sâdât-ı kirâmdan es-Seyyid Abdülaziz dẩileri Bağdad eyâletinde vâkı hazret-i İmam Ali ve İmam Hüseyin ve İmam Mûsâ Kâzım radiy allahu teâlâ anhum evkafında feth-i hakanîden beri berât-ı şerîf-i âlişân ile mütevelli olup, evkaf-ı mezbûre tevliyetine müteallık olan hizmet-i lâzımesinde bir türlü kusûru yok iken, âhardan rafz ile müteârif Abbas nâm kimse mukaddemen Kızılbaş-ı bed-maaş yanında olup, hâlen karındaşı ve karındaşı oğlu Şah yanında iken hilâf inhâ ile tevliyet-i mezbûreyi akrabasından Seyyid Zeyd 
nâm kimse üzerine hatt-ı hümâyun-ı şevket-makrûn ile mu’anven berât ettirip, ol vechle merkûma külli gadr eyledikten gayrı, evkaf-ı mezbûre malından kendileri ekl ü bel' etmeleriyle, mezbûrân Abbas ve Zeyd ref' ve tevliyet-i mezkûre geri merkum dầilerine ibka vü mukarrer ve yedine berât-ı şerîf-i âlişân sadaka vü ihsân buyurulup mezburların hilâf inhâ ile aldıkları berat ellerinden alınıp Der-i Devlet-masîre gönderilmek bâbında fermân-ı cihân-mutâ' ricâsına arz olundu. Baki ferman Dergâh-ı ma'delet-penâhındır.

bende Mustafa

tevliyet-i evkaf-ı hazret-i İmam Ali ve İmam Hüseyin ve Mûsâ Kâzım ve Muhammed? der Bağdad:

der uhde-i Seyyid Abdülaziz

Zikr olunan evkafın tevliyeti üzerinde iken âhardan Abbas nâm kimse alıp dahl etmekle, mezbur Seyid Abdülaziz'de mukaddemen mukarrer olup yedine berât-ı âlişân verilmiş iken, yine kanaat etmeyip dahl etmekle, elinde olan berâtı mûcibince bin yetmiş dokuz Rebîülâhirinin on birinci gününde sûreti ruus-ı hümâyun mûcibince mezkur Seyyid Abdülaziz'e ibka vu mukarrer olduğu defterde mastur[dur]. Ferman saadetlü sultânım hazretlerinindir. fî 24 Ş [aban] s[en]e 1079

[kuyruklu defterdar imzâsı]

$S A H H$. ÂSİTÂNE-I SAADET'TE SEYYİD ABDÜLAZİZ ÜZERİNDE OLMAKLA KEMÂKÂN MUKARRER OLUP, VE MEZKUR ABBAS'IN ELINDE OLAN TEMESSÜKÂT DER-KÎSE OLUNUP RİKÂB-I HÜMÂYUN'A İRSÂL OLUNMAK İÇİN, BAĞDAD MUHÂFIZI VEZÎR-I MÜKERREM SAADETLÜ VE RIF'P'ATLÜ MUSTAFA PAŞA HAZRETLERINE HÜKÜM YAZILMAK BUYURULDU! fì $28 S$ [aban] s[en]e 1079

\section{Belge 3 (iE.EV. 13/1576)}

Hüccet-i Şer'iye

$H \hat{u}$

Hıfzı Abdurrahman b. Eyüb el-kâdı bi-dârü'l-cihâd medîne-i Bağdâd elmahmiyye 'ani'l-azdâd

[imzâ, mühür] 
Sebeb-i tahrîr-i kitap oldur ki:

Hazret-i İmam Hüseyin radıyallahuteâlâanh âsitânesinde olan câmi'ü'n-nisâ ve dârü'l-huffâz, ve hazret-i İmam Abbas'ın âsitânesinde câmi'ü'n-nisâ ve merkadi şerîfin üst kubbesi ve câmi'-i şerîfin kubbeleri tamire muhtaç olmakla mukaddemen evkaf-ı mezbûre mütevellisi es-Seyyid Abdülaziz "mârü'z-zikr tamir ancak on sekiz kese ile olur" diye keşf ettirip ve minvâl-i muharrer üzere dîvân-ı Bağdad'a arz u îlâm etmekle bu fakir bilfiil muhâfız-ı vilayet-i Bağdad olan destûr-i zîşân, vezîr-i Âsaf-nişân, müdebbir-i umûr-ı âlem, mükemmil-i kusûr-ı ümem, sahib-i rây-i zerîn, mâlik-i fikr-i metîn, devletlü ve saadetlü Mustafa Paşa yeser allahu lehu mine'l-hayr mâ-yeşâ hazretlerinin taraf-ı şerîflerinden mübâşir tayin olunan fahrü’l-akrân ...... Mehmed Ağa ve hassa mimarlardan el-Hac Mehmed ve Üstad Derviş ve zeyl-i kitapta mastûrü'l-esâmî olan ehl-i hıbre ile mahall-i mezbûra varıp, mukaddemen mütevelli-yi mezbur "one sekiz kese ile olur" diye keşf ettirdiği mevâzi'e nazar u müşâhede olundukta hazret-i İmam Hüseyin’in âsitânesinde olan câmi'ü'n-nisâ ve dârü'l-huffâzın kubbeleri ve hazret-i İmam Abbas'ın âsitânesinde olan câmi'-i şerîfin kubbesi ve kemerleri müceddeden tamire muhtaç olup, ve sâir İmam Abbas'ın merkadinin üst kubbesi ve câmi'ü’n-nisânın kubbesi ve merkadin kâşîsi ve sâir mevâzi'i tamire muhtaç olup, cümle tamir ü termîm ve sıvamağı "ancak iki bin kuruş ile olur, meblağ-ı mezburdan eksik ile olmaz" diye mezbûrân el-Hac Mehmed ve Üstad Derviş ve sâir ehl-i hıbre takvîm ü tahmin ve mârü’z-zikr tamir ü termîm ve sıvamağın küllîsi meblağ-ı mezbûr iki bin kuruşa kendileri etmek üzere taahhüd ve kabul etmeğin, mâ-vak’a bi't-talep ketb olundu. Tahrîren fî̀l-yevmü's-sâlis aşer min Zilhiccetü’ş-şerîfe li-sene semânîn ve elf.

Şuhûdü'l-hâl

mevlânâ Mahmud Efendi el-vâiz, mevlânâ Mehmed Efendi el-hatîb, mevlânâ Halil Efendi el-hatîb, mevlânâ Hasbî Efendi el-hatîb, Ahmed Çelebi serdâr-ı sâbık, el-Hac Mehmed b. Abdullah

\section{Belge 4 (A.DVN. 64/33) \\ Hüccet-i Şer'iye}

Şeyh Mehmed el-mevlâ li-medîne Bağdad ....... [mühür:] hidâyet-i ezelî rehber-i Mehmed bâd

Sebeb-i tahrîr-i kitap oldur ki:

Hılâl-i sutûrda muharrer ve mastûr olan husûs-ı âtiyü’l-beyân için bilfiil vâliyi vilayet-i Bağdad-ı bihişt-âbâd olan destûr-i mükerrem, vezîr-i Âsaf-nazîr, 
saadetlü Hüseyin Paşa .......... hazretleri dîvân-ı âlîlerinde akd-i meclis-i şer'-i münîf olundukta, mukaddemen şekaavet ü fesatlarına binâen ahz olunan sekban tâifesinden Seyfi b. Ahmed ve bayraksız levendâttan Deli Ali ve Arapoğlu ve Urfalı Mehmed ve Kürt İbrâhim ve Kürt Ali ve Ahmed nâm kimseler ıhzâr olunup mezbûrûnun keyfiyet-i ahvâlleri hâzirûn bi'l-meclis olanlardan sual olundukta, gönüllüyân-ı yesâr bölükbaşısı Osman-beyg ve Hasan-beyg b. Abdullah ve İslam-beyg bin Abdullah ve Kasım b. Hasan ve Kenan b. Abdullah ve Mahmud b. Mehmed ve sâirleri "mezbûrûn Seyfi ve Deli Ali ve Arapoğlu ve Urfalı Mehmed ve Kürt İbrâhim ve Kürt Ali ve Ahmed bundan akdem hazreti İmam Hüseyin radıyallahuteâlâanhu ziyâretini kast eden kervanın önlerine durup mallarını gaaret etmek kastıyla hücum ettikleri esnâda biz dahi üzerlerine varıp kat'-i tarik ettiklerini müşâhede eyledik, mezbur Seyfi ile mezbûrûn Deli Ali ve Arapoğlu ve Urfalı Mehmed ve Kürt İbrâhim ve Kürt Ali ve Ahmed dâima kat'-i tarik edip sâ̂î bi'l-fesâd oldukları malumumuzdur" diye her biri mezbûrûnun muvâcehelerinden makam-ı şehâdette haber vermeğin, vâkı'-i hâl bi't-talep ketb olundu. Hurrire fìt-tâsi aşer min şehr-i Şevvalül-mükerrem li-sene isnâ ve semânîn ve elf.

[şühûdü'l-hâl]

farhü'l-müderrisîn Mahmud Efendi el-vâiz, fahrü'l-eimme Molla Yusuf b. —, umdetü'l-emâcid ve'l-ekâbir Adlî Mustafa Efendi, zübdetü'l-ekârim ... Abdullah Efendi el-defterî, mefharü'l-küttâb İsmâil Efendi rûz-nameci, fahrü'l-eşbâh Mustafa Ağa el-muhzır, fahrül-a'yân Hüseyin Çelebi kethüdâ-yı çavuşân, Hüseyin Çelebi b. el-Hac Hasan et-tercümân

\section{Belge 5 (íE.EV. 19/2287)}

\section{Telhis}

Hû!

Arz-ı bende-i bî-mikdâr budur ki, şevketlü ve kerâmetlü ve mehâbetlü Pâdişâhım!

Bağdad'da hazret-i İmam Hüseyin radiyallahuteâlâanh hazretleri câmi-i şerîflerinin hitâbeti mahlûle olmağın, müstehak olan sulbî oğlu Abdülfettah’a sadaka buyurulmak ricâsına Bağdad hazînesinden mahallinden sûret-i tezkire verilmekle, emr ü fermân şevketlü ve kerâmetlü ve mehâbetlü pâdişâhımındır.

$f^{\imath}{ }_{5}[$ Şevva $]$ Ls $[$ en $]$ e $[10] 90$ 


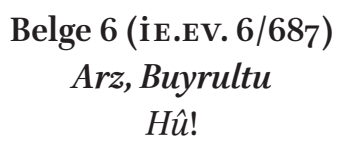

Der-i Devlet-mekîne arz-ı bende-i kemîne budur ki: Bağdâd-ı bihişt-âbâdda vâkı Meşhedeynü'ş-Şerîfeyn evkafından yevmî on akçe vazîfe ve senevî on altı dağar hınta ile duâ-gûy olan el-Hac Hasan ibn-i Hamza fevt olup mahlûl olmağın, yevmî beş akçe ve senevî sekir dağar hıntası vakıf-mânde olunup beş akçe ile sekiz dağar hıntası bâis-i arz-ı rıkkıyet Molla Ali bin Molla Sultan dầileri müstehak olmakla, tevcîh ü inâyet buyurulmak ricâsına Der-i Devlet-medâra arz olundu.

Baki emr ü ferman Der-i [ma'delet-]ünvânındır. abd-i fakir: Yusuf, ağa-yı Dârü’s-Sa'âdeti'ş-şerîfe ve’n-Nâzır, hâlen

SAHH. MÛCEBİNCE TEVCÎH OLUNMAK BUYURULDU! $7[$ Ramaza $] N s[$ en $]$ e $[10] 96$

\author{
Belge 7 (TSMA.E. 1288/102) \\ Arz üzerine derkenâr [ve silinmiş buyrultu]:
}

Devletlü ve saadetlü Sultânım hazretlerinin hâk-i pây-i şerîflerine rûy-i ubûdiyet mâlîde kılındıktan sonra arz-ı bende-i bî-mikdâr budur ki

Meşhedeyni'ş-Şerîfeyn evkafindan yevmî on dört akçe vazîfe ve senevî on dağar hinta cerâye ile İmam Hüseyin hazretlerinin âsitânesinde ferrâş olan Molla Muhammed b. Molla Abdürrezzak fevt olup yeri mahlûle olmak ile, sulbî oğlu bâis-i arz-ı ubûdiyet Molla Halil b. Molla Muhammed bendeleri mahall ve müstehak olmağın, zikr olunan cihetten yevmî yedi akçe vazîfe ve senevî beş dağar hinta cerâye ile ferrâş olmağa tevcih, vazîfe ve cerâye-i merkûmesi Haremeyn-i Şerîfeyn defterinde mukayyed bulunmağın, berât-ı şerîf-i âlişân verilmek bâbında arz-ı şerîfleri ricâsına arz olundu. Baki emr ü fermân devletlü sultânımındır.

bende:

Ali, mütevelli-yi vakf-ı Meşhedeyni'ş-Şerîfeyn

Tahrîr-i cedîde kayd şude fì 15 Z[ilhicce $]$ se [ne $] 1098$

Der Nezâret-i hazret-i ağa-yı Dârüsaadetişs-Şerîfe

Ber-Mûcib-i defter-i hızâne-i evkaf-ı şerîf-i Meşhedeyni’̧s-Şerîfeyn (radîallahuteâlâanhüma) der Bağdâd-ı bihişt-âbâd 
Molla Muhammed b. Molla Abdürrezzak, ferrâş-ı âsitâne-i hazret-i İmam Hüseyin

Yevm:XIV/14

Fî Sene: hinta, dağar, $X$

Vech-i meşrûh üzere Hazîne-i Âmire defterinde mastûr u mukayyettir. Baki ferman devletlü sultânım hazretlerinindir. fî 23 C[emâziyü'l-]E[vvel], se[ne] 1099 [kuyruklu defterdar imzâsı]

\section{Belge 8 (TSMA.E. 1166/43) arzıhâl ve derkenârda ilam}

fî 27 [Rece]b, se[ne] 1099

Saadetlü ve merhametlü Sultânım hazretleri sağ olsun!

Bağdad'da hazret-i İmam Hüseyin radiyallahuanh hazretlerinin evlâdından hâlen İmâm-ı müşârünileyh kasabasında nakıybü'l-eşrâf olan babamız esSeyyid Abdülmuttalib İmâm-ı müşârünileyh hazretlerinin sahîhü’n-neseb evlâdından olup, ve nakâbet-i mezbûre dahi evlâd-ü-evlâda meşrut olmağun, vech-i mezkûrede meşrûtamız olan yevmî yirmi akçe vazîfe ve sûku'l-gazl ve kapân ve nehr-i Seyb'de bir feddân ve nehr-i Cûbiye'de bir feddân ve boyahâne muâfiyeti evlâd-ı evlâda meşrût olmağın, evladdan olup berât-ı şerîf ile mutasarrıf olan babamız bi-emru'llah-ı teâlâ bunda fevt olup nöbet-i tasarruf bu bendelerine intikal etmeğin, saadetlü sultânımdan mercûdur ki, babamız müteveffâ ve merhum mahlûlünden bu dầilerine olmak üzere arz-ı şerîfleri sadaka vü ihsân buyurulmak bâbında

baki ferman mürüvvetlü sultânım hazretlerinindir.

ed-dầi: Seyyid Murtazâ

ed-dầi: Seyyid Abd[ullah]

ed-dầi: es-Seyyid Muhammed, en-nakıyb hâlen

MAHALLİ GÖRÜLE!

Zikr olunan kurâlar ve boya-hâne ve sûku'l-gazl ve kapân vakf-ı şerîf tarafindan zabt olunmak üzere tahrîr-i cedîd defterine dâhil olmuş iken, İmâm Hüseyin radiallahuteâlâanh hazretlerinin kasabasında evlâddan nakıbü̈'l-eşrâf olan Seyyid Abdülmuttalib evlâd-ı evlâda meşrûtaları olan yevmî yirmi akçe duâguyî vazîfesi ve sûku'l-gazl ve kapâniye ve nehr-i Seyb'de bir feddân ve Cûbiye'de bir feddân ve muâfiyet-i boya-hâne meşrûtaları iken, sâbıkan vakf-ı şerîf mütevellisi Basralı Ali hilâf inhâ ve defter-i cedîde kayd ettirmekle nakıyb olanlara meşrûta olmak üzere tahrîr-i cedidden ihrâc ve mahalline kayd u şerh verilmek üzere fermân-i hümâyun sâdır olmağın, vech-i meşrûh üzere mahalline kayd 
u şerh verildiği tahrîr-i cedîd defterinde mastûr u mukayyeddir. Emr ü ferman devletlü sultânımındır.

23 [Ramaza]N, se[ne] 1099

[defterdar imzâsı]

\author{
Belge 9 (TMSA. E. 833/25) \\ arzıhâl, arz, derkenâr, ilam, ve buyrultu \\ fî 3 [Ramaza]n, se[ne] 1099
}

$H \hat{u} !$

Devletlü ve saadetlü Sultânım hazretleri sağ olsun!

Bu dâileri Meşhedeynü’ş-Şerîfeyn evkafindan yevmî yirmi akçe vazîfe ve senede on dağar hınta cerâye tekaaüd ile olup, hâliyâ hüsn-i rıâm ile kendi sulbî oğlum es-Seyyid Muhammed kullarına ferâgat edip, devletlü ve saadetlü sultânım hazretlerinin merâhim-i aliyyelerinden mercûdur ki, zikr olunan vazîfem ve cerâyem ?siyle mezbur oğlum kullarına tevcih ve vazîfe-i merkûmum Haremeynü’ş-Şerîfeyn defterinde mukayyed bulunmağın yedine berât-ı şerîf-i âlişân verilmek bâbında arz-ı şerîfleri ricâ olunup, baki emr ü ferman sultânımındır.

bende: Seyyid Abdülmuttalib

Maruz-ı dâii-yi devletleri budur ki

Arz sâhibi mezbur Seyyid Abdülmuttalib marîz ü esîr-i firâş olup kendi hâzır olmağa kaadir olmadığı ecilden, ceriyye-i mezkûreyi sulbî oğlu Seyyid Muhammed'e ferâgaten, tarafindan Hacı Sâlim b. Hacı Abdullah nâm kimseyi vekîl eylediği huzûr-ı şer'de el-Hac Muhammed Nakıy b. el-Hac Hamza ve eş-Şeyh Ahmed b. Hacı Süveyd el-Bağdâdî şehâdetleriyle sâbit olduğu huzûra arz olundu. Baki emr velî-yi emr hazretlerinindir.

mine'd-dâ'i: Ali, el-müfettiş

[Ali'nin mührü]

MAHALLİ GÖRÜLE!

Der Nezâret-i hazret-i Ağa-yı Darüssaadetüş-Şerîfe

Ber-mûcib-i defter-i hazîne-i evkaf-ı şerîf-i Meşhedeynüsş-Şerîfeyn radiallahuteâlâanhum der Bağdâd-ı bihişt-âbâd:

Seyyid Abdülmuttalib:

tekaaud, yevmîx

senevî, hınta, dağar, $x$

Vech-i meşrûh üzere zikr olunan tekaaüdlük yevmî yirmi akçe vazîfe ve senede on dağar hınta cerâye ile sâhib-i arzıhâl es-Seyyid Abdülmuttalib üzerinde 
olduğu Hazîne-i Âmire defterinde mastûr u mukayyeddir. Baki emr [ü] fermân devletlü sultânımındır.

fî 20 Zi[lka'de], se[ne] 1099

[defterdar imzâsı]

HAREMEYN-İ ŞERÎFEYN MÜFETTIŞi̇ EFENDİ! ŞER'İLE GÖRÜLMEK BUYURULDU!

\section{Belge 10 (iE.EV. 25/2938)}

\section{Ferman}

Hû!

\section{Şah Ahmed b. İbrâhim Han el-muzaffer dâimâ}

Destûr-i mükerrem, müşîr-i müfahham, nizâmü'l-âlem, müdebbir-i umûri cumhûr bi'l-fikri's-sâkıb, mütemmim-i mehâmmi'l-enâm bi'r-reyi's-sâib, mümehhid-i bünyânü'd-devle ve'l-ikbâl, müşeyyidü'l-erkâni's-saâde ve'l iclâl, el-mahfûf bi-sunûf-i avâtıfi'l-Meliki'l-A'lâ, Bağdad vâlisi olan vezîrim Ahmed Paşa edâmallahuteâlâiclâlehu, ve akzâ-i kuzati'l-Müslimîn, evlâ-yı vülâti'l-Muvahhidîn, ma'denü'l-fazl ve'l-yakıyn, râf'ü'l-a'lâmi'ş-şerî̀a ve’d-dîn, vâris-i ulûmi'l-enbiyâ ve'l-mürselîn, el-muhtass bi-mezîd-i inâyeti'l-Meliki'lMu’în, mevlânâ Bağdad kadısı zîdetfazluhu, tevkıy'-i refî̀-i hümâyunum vâsıl olucak malum ola ki,

Bağdâd-ı bihişt-âbâdda vâkı Meşhedeyni'ş-Şerîfeyn-i hazret-i İmam Ali ve İmam Hüseyin radiallahuteâlâanhüma evkafının hatt-ı hümâyun-ı şevketmakrûnumla ber-vech-i [te’bîd mütevellisi] olan Muhammed Nakuyeddin Ordu-yı Hümâyun'uma arzıhâl gönderip, vakf-ı mezbûr Dârüsaade Ağası nezâretinde olup mefrûzü'l-kalem ve maktû'u'l-kadem serbest iken, Bağdad vâlileri nezâret a[kçesi] ve kapı harcı nâmıyla ve haşemât ve karakol ve gümrük emînleri ve sâir 'ammâl tâifesi hilâf-ı şer’ u kanun dahl ü taarruz edip, ve sâbıkan Bağdad vâlisi tevliyet-i merkûme hizmetinde ...66 edip nezâret akçesi nâmıyla kendi için iki bin beşyüz kuruş ve kethüdâsına bin kuruş ve kapı harcı nâmıyla hazînedâr-ı sâbık-ı Bağdad beş yüz kuruş ve vekil-harç Mehmed beş yüz kuruş [ve] ... ${ }^{67}$ beş yüz kuruş ve Mustafa iki yüz yirmi beş kuruş ve çukadar beşeler ikiyüz on kuruş ve mütesellimi Ali yüz sekiz kuruş ve Hille zâbiti altı yüz kuruş ve Mehâvîn? karyesi vakf-ı mezbûrun mülhakkâtından iken yüz iki ve yüz üç senelerine be-her sene hâsıl olan nukûdu ve beş yüz dağar mahsûlü vakfa zabt ettirmeyip kendi tarafindan zabt ve ahz ü kabz eylemekle min-haysi'l-mecmû' yedi bin dört yüz on kuruş nukûdu ve bi[n] d[ağar] ğ[alâli] mâl-ı vakftan

66 Kağıt yazının üstüne katlanmış.

$67 \quad$ Kağıt sözcüğün üstüne katlanmış. 
zulmen ve cebren ahz ü kabz eyleyip hazer etmemeğin, Haremeyn-i Şerîfeyn muhâsebesi defterine nazar olundukda Bağdâd-ı bihişt-âbâdda vâkı Meşhedeyn-i İmam Ali ve İmam Hüseyin ve İmam Abbas radiallahuteâlâanhüm hazretlerinin evkaf-ı şerîfeleri merfûzüll-kalem ve maktû'u'l-kadem min külli'l-vücûh serbest olmakla, Bağdad vâlileri nezâret akçesi ve kapı harcı bir akçe ve bir habbe almamak üzere ve haşemât ağaları ve karakol ağaları ve Hille zâbitleri ve kadıları ve sâir ümenâ ve 'ammâl tâifesi dahl ü taarruz eylememek üzere serbest olduğu mastûr bulunmakla, şer'le teveccüh eden mâl-i vakf Paşa-yı müşârunileyhten ve mezkûrü'l-ism olanlardan bi't-tamâm tahsil olunmak için Dergâh-ı Muallầm kapıcılarından [] zîdekadruhu tayin ve mâliye tarafından emr-i şerîfim verilmekle, mûcebince amel olunmak bâbında hükmi hümâyunum ricâ eylediği ecilden, mâliye tarafından verilen emr-i şerîfim mûcibince amel olunmak emrim olmuştur. Buyurdum ki,

vusul buldukda, bu bâbda sâdır olan fermân-ı celîlü'l-kadrim ve mâliye tarafından verilen emr-i şerîfim mûcibince amel edip min-ba'd hilâfına rızâ vü cevâz göstermeyesin! Şöyle bilesin, alâmet-i şerîfe i’timâd kılasın!

Tahrîren evâsıt-ı Şevval, sene sülüs ve mîe ve elf be-yurt-i sahrâ-yı Edirne

\section{Belge 11 (MHM.d. 104, madde 224) Mühimme'de ferman özeti}

Bağdad vâlisi vezîr Ahmed Paşa'ya ve Bağdad mollasına hüküm ki İftihârü'l-havâss ve'l- mukarrebîn, mu’temedü'l-mülûk ve's-selâtîn, bilfiil Dârüssaadet'im ağası olan Nezir Ağa dâmeuluvvihu'nun taht-ı nezâretinde olan evkaftan Bağdad'da vâkı hazret-i İmam Ali radîallahuteâlâanh evkaf-ı şerîfesinin tevliyeti kıdvetü'l-havâss ve'l-mukarrebîn Muhassıl Abdullah Ağa dâmeuluvvihu'ya tevcih olunup, mütevelli-yi sâbık Muhammed Nakıy vakfa vâfir akçesi sebkat etmek üzere iddiâ etmekle, imdi siz ki vezîr-i müşârunileyh ve mevlânâ-yı mûmâileyhsiz, hâlen mütevelli-yi sâbıkın şer’ile muhâsebesi görülüp îrâd ü masârıfı müfredât defterleriyle yerli yerinde hakk-ı adl üzere teftiş ve tefahhus olunup fi'l-hakîka merkumun vakıfta alacağg sâbit ü zâhir olur ise sûret-i sicilleriyle sıhhat ü vukû’u üzere Rikâb-ı Hümâyun'uma arz eylemeniz bâbında

diye yazılmıştır.

fî evâsıt-ı [Şevva]L, se[ne 1]103 


\section{Belge 12 (NMH.d. 5, madde 86) \\ nâme —resmî defter sûreti}

\section{Emîr-i Mekke-imükerremeye name-i hümâyundur}

Cenâb-ı emâret-meâb, iyâlet-nisâb, saadet-iktisâb, siyâdet-intisâb, zu’n-nesebi't-tâhir ve'l-hasebi'z-zâhir, müstecmi'i'l-menâkıb ve'l-mefâhir kâbiren-ankâbir, cemâlü’s-sülâleti'l-Hâşimiye, fer'i'ş-şereceti'z-zekiyyeti'n-Nebeviyye, tırazü'l-1sâbeti'l-Aleviyye, umdet-i âli'r-Resûl, kurretü'l-ayni'z-Zehrâ'i'l-Betûl, el-mahfûf bi-sunûf-i avâtıfi'l-Melik-i zi'l-kuvve ve'l-eyd, emir-i Mekketi'lmükerreme Şerîf Sa'd b. Zeyd dâmesa'duhu tevkıy'-i refî'-i cihân-mutâ’mız vâsıl olacak mâlum ola ki

Geçen sene surre emîni olan Zülfikar dâmemecduhu ile gönderilen mektûb-i sadâkat-mashûbunuzun hülâsa-i mefhûmu pâye-i serîr-i saadet-masîr-i hüsrevânemize arz olunup, seciyye-i behiyyenizde münderiç ve muntavi olan emâret $u$ asâlet $u$ alâmet $u$ necâbet muktezâsı üzere hizmet-i emâret-i Mekke-i mükerremede bezl-i miknet ve sarf-ı sa’y u kudret eylediğinizden mâ’adâ tâif-i Beytullahi'l-Harâm ve zâir-i Ravza-i Mutahhara-i hazret-i Seyyidül-Enâm olan hüccâc-ı zü'l-ibtihâcın refâh-i hâl ü ferâğ-ı bâl ile iyâb ü zehâblarında ve eşref-i bilâd-ı Rûy-i Zemîn olan beledu'llahi'l-emîn ahâlisinin ve sâir havza-i hükûmet ve havme-i emâretinizde olan aktâr-ı Hicâziye'nin intisâk u intizâmında hüsn-i ihtimâmınız muhât-ı ilm-i âlem-şümûl-i hüsrevânemiz olup, duâ-yı hayr-ı icâbet-eser-i mülûkâne ve hüsn-i tecevvüh-i hüsrevânemize mazhar olmuşsu[nu]zdur. Üsre-i necâbet-eserlerinde olan alâmet-i şerâfet mübtegâsı üzere fîmâ-ba'd dahi sıdk-ı niyyet ve safâ-yı taviyyet ile me'ser-i pesendîde melhûz-i hümâyunumuz olmakla, hakkınızda neyyir-i ziyâ-efrûz-i atûfeti pâdişâhânemiz sâtı’ ve lâmi' olup, hassa hıla'-i fâhire-i mülûkâne ve kisvei bâhire-i hüsrevânemizden semmur-i fâyizü’s-sürûra kaplı bir sevb hil'at-i mûrisi'l-behcet-i sultâni inâyet ve ihsânımız olmağın, teblî̆i hizmetiyle hassa silahşörlerimden kıdvetü'l-emâcid ve'l-a'yân [] zîdemecduhu tayin ve name-i hümâyun-ı mülâtafat-nümûnumuz ısdâr u irsâl olunmuştur. Lede'l-vusûl, bu Dûdmân-ı Muhalledü’l-erkân ü bu Hânedân-ı Refî̀ül-bünyâna olan vüfûr-ı sadâkat ve istikamet muktezâsı ve rüsûh-ı sıdk u safâ-yı taviyyetiniz müsted'âsı üzere hil’at-i fâhiremizi merâsim-i i'tibâr ü ibticâl ile istikbâl ve iktisâ edip kesbi sürûr ü ibtihâc eyledikten sonra terfîh-i ahvâl-i sükkân-i Haremeyn ve te'min-i kuttân-ı Makâmeyn-i münîfeyn ve her fecc-i amıyktan ziyâret-i Beyt-i Atıyk için gelen hüccâc ü züvvârın hıfz u hırâseti ve müsâfirîn ü tüccârın himâyet ü slyâneti husûsunda mücidd ü sầi ve kesîrü'l-mesẩi olup, siyyemâ bundan esbak müteahhid olduğunuz üzere hüccâc-ı bâ-ibtihâcın 'Alâ menzilinden Medâin-i 
Sâlih’e değin istikbâl ü teşyî̀ vü Urbân eşkıyâsından hıfz u vıkâyelerinde i’mâl-i himmet edip, bâ-husûs ecdâd-ı âlî-nejâd ü ebâ-i bihişt-maâadımız—tayyib allah rûhum ve ce'le-firdevs mâ-fîhum ve mesvâhum - hazretlerinin ezmine-i saadet-iktirânlarından ilâ-yevmenâ-hezâ şâh-ı vâlâ-câh-ı Acem ile miyânede mübrem ü müstahkem ve tarafından makbûl ü müsellem olan kavâid-i sulh u salâha tarafınızdan dahi mürâât ve hüccâc-ı Acem'in rakabelerine darb-ı mükûs olunmayıp sâdır olan hatt-ı hümâyun-ı şevket-makrûnum mûcibince himâyet ü sıyânet olunup, bi'l-cümle aktâr-ı Hicâziye'nin tensıyk-i umûr-ı cumhûrunda ve istikamet-i ahvâl-i hüccâcda ve uhde-i himmetinize mufavvez olan hususların küllîsinde bezl-i cell-i himmet edip, hakkınızda tazầuf-ı iltifâti mülûkânemizi müsted'î olur âsâr-ı cemîle vücûda getirmeğe hüsn-i ihtimâm eyleyesi[ni]z! Şöyle bilesiz! evâsit-ı [Rece]b, sene [1]107

\section{Belge 13 (мнм.d. 110, madde 1259) Mühimme'de ferman özeti}

Halep vâlisine ve Şam beylerbeyisine, Halep ve Şâm-ı şerîf mollalarına ve ... ve ... kadılarına hüküm ki

Acem hüccâcından olanlar arzıhâl edip, bunlar Acem hüccâcından olup mürûr u ubûr eyledikleri mahallerde bir vechle dahl ü rencîde olunmayalar diye hatt-ı hümâyun-ı saadet-makrûn ile emr-i şerîf vârid olmuş iken, Şâm-i şerîf sâkinlerinden Tebrizli ${ }^{68}$ Hacı Mustafa demekle maruf kimse Malatya'da bunların önlerine gelip hacc-ı şerîfe giderler iken her birinden ikişer altın ve avdette birer altın aldığından mâadâ, berat ve kılavuz akçesi nâmıyla dahi cebren akçelerini alıp zulm ü taaddi etmekle, men' olunmak bâbında hükm-i hümâyunum $[u]$ ricâ eyledikleri ecilden, bu makule hilâf-ı şer’ zulm ü taaddi vâkı ise mukaddemen verilen fermân-ı şerîfim mûcibince amel olunup men’ olunmak üzere yazılmıştır.

fî evâsıt-ı [Rece]b, se[ne 1]1o9

Belge 14 (A.DVN. 257/5 and 257/6)
Arzihâl, buyrultu, ferman taslağ

Devletlü ve saadetlü Sultânım hazretleri sağ olsun!

68 Tabriz is misspelled here as "Tabris." 
Arzıhâl-i kulları oldur ki: Acemden gelen hüccâcînin akkâmlarına Hüseyin kulları akkâmbaşı olmak için fermân-ı şerîf ricâ olunur. Baki ferman sultânımındır.

bende:

Saîd, Acemler’in mühimmâtına vekîl olan

$S A H H$.

MÛCEBINCE MÜEKKED HÜKÜM

BUYURULDU!

\section{$H \hat{u} !$}

Dergâh-ı Mualla’m kapıcıbaşılığı pâyesine mutasarrıf olup hüccâc-ı Acem’in mürûr u ubûrları için vekil olan Hüseyin dâmemecduhu' ya hüküm ki Hüccâc-ı Acem’in mühimmâtına vekil olan fahrü'l-akrân Saîd zîdesa'dehu Südde-i Saadet'ime arzıhâl edip, edâ-yı farz-ı hacc için diyâr-ı Acem'den Haremeyn-i Şerîfeyn tarafına tevcîh-i veche kasd u azîmet eden hüccâc ü züvvâr-ı Acem’in akkâmları üzerine Hüseyin nâm kimse akkambaşı nasb u tayin ve hizmet-i mezbûrda istihdam olunmak bâbında hükm-i hümâyunum ricâ etmeğin, vech-i meşrûh üzere amel olunmak bâbında fermân-ı âlişânım sâdır olmuştur. Buyurdum ki ...

fî evâil-i R[ebî́ülâhir] s[en]e [1]111

\section{Belge 15 (м нм.d. 112, madde 1430) \\ Mühimme'de ferman özeti}

Erzurum vâlisine ve ... ve ... ve ... kadılarına hüküm ki

Hassa teberdarlarım emektarlardından Mahmud zîdekadruhu Dergâh-ı Muallâ'ma arzıhâl gönderip, diyâr-ı Acem'den ıskaat-ı farîza-i hacc ü ziyâreti meşâhid-i müşerrefe vü merâkıd-ı müteberrike için şedd-i zâmile-i azîmet eden hüccâc ü züvvârın hizmet-i kıyâdeti hatt-ı hümâyun-ı şevket-makrûnumla ber vech-i te'bîd kendiye inâyet ü ihsânım olmakla, mûmâileyh dahi tavâf-ı Beytullah-ı Harâm ve ziyâret-i Ravza-i Mutahhara-i hazret-i Seyyidü’l-Enâm ve sâir meşâhid-i müşerrefe niyeti ile diyâr-ı Îrân'dan ol emâkin-i müteberrikeye âzim olan hüccâc ü züvvârın emn ü selâmetle iyâb ü zehâblarına takayyüd ve memur olduğu hizmet-i klyâdeti sadâkat ü istikametle edâ etmek istedikte, hâlen Alakuş demekle maruf Ali ve Abdullah nâm Acemler bazı kimseleri tahrik ve memur olduğu hizmet-i kıyâdete mürûruna mümâna’at eylediklerin[i] bildirip, ol bapta hükm-i hümâyunum[u] ricâ etmeğin, mezbûrun memur olduğu hizmete mürûr u ubûruna kimse mâni' ü müzâhim olmamak ... 
için yazılmıştır.

fî evâil-i [Ramaza]n, se[ne 1]114

\section{Belge 16 (A. DVN. 316/14, sene 1117) arzihal, buyrultu}

Devletlü ve saadetlü Sultânım hazretleri sağ olsun!

Bu kulları Acem ağası olup, diyâr-ı Îran'dan vâkı olan hüccâc-ı A'câm be-hersene yedişer ve sekizer yüz kuruş mutâlebesiyle Maarre sancakbeyi tarafindan rencide vü ta'addî olunup gadr edilmekle, mercûdur ki, mezbûrun bî-vech-i şer̂̂̂ mutâlebesi men’ olunup ve bu sene aldığı sekiz yüz kuruş ashâbına redd ü teslîm olunmak bâbında Halep vâlisine ve kadısına hitâben ferman sultânımındır.

bende: Eyüb

SAHH.

MÛCEBİNCE TA’ADDÎ OLUNMAYA DİYE HÜKÜM

$B U Y U R U L D U$ !

\section{Belge 17 (A.DVN. 340/18, sene 1118) \\ arzıhâl, buyrultu \\ Hû!}

Devletlü ve saadetlü efendim Sultânım hazretleri sağ olsun! Arzıhâl-i kulları budur ki: Bu kulları Acem hacılarından olup, Halep diyârına gelip dâhil oldukta, akkâm kısmı ve gerek devecisi vesâir bu minvâl üzere olan kimseler bilâfermânîn "bizlerin avâyidimiz vardır" diye hilâf-ı şerî ve hilâf-ı kanun avâid talebiyle rencîde vü remîde ettikleri ecilden, devletlü efendimizin merâhimi aliyyelerinden mercûdur ki, "bu makule hilâf-ı şer̂î ve hilâf-ı kanun bilâfermânîn rencîde vü remîde olunmasın" diye Halep vâlisine ve mollasına ve üzerimizde olan ağaya hitâben fermân-ı âlî ricâ olunur. Bu bâpta emr ü fermân sultânım hazretlerinindir.

bende: Acem hacıları

SAHH. HİLÂF-I ŞER'-I ŞERÎF AVÂID TALEBIYYLE RENCİDE OLUNMAYALAR DİYE HÜKÜM BUYURULDU! 


\section{Belge 18 (мнм. d. 118, madde 1172) \\ Mühimme'de ferman özeti}

Erzurum mollasına ve mütesellimine hüküm ki

Hâlen hüccâc-ı Acem’in kaaidi olan Mahmud zîdekadruhu ile karındaşları Ahmed ve Mehmed nâm kimseler gelip, bunlar bin yüz yirmi senesinde hacc-ı şerîfe giderler iken Eyüb nâm kimse ve havasına tâbi Kutlu nâm yeniçeri ve Acem Ali nâm kimseler ile yek-dil olmalarıyla, Hasankeyf kazâsı durağına geldiklerinde önlerine inip, ahz ü der-zincir edip, ba'dehu Diyarbekire götürüp on gün mikdârı hapis ve yanlarında mevcut bulunan malumü'l-[mi]kd[â]r akçe vü emvâl ü eşyâların[1] cebren ve bi-gayrü'l-hakk gasp eyleyip, küllî gadr ü taaddi vü tecâvüz eyledikleri[i] ve mezbûrlar hâlen Erzurum'da oldukların[1] bildirip, zâbitleri marifetiyle şer'le görülüp taraf-ı şer'den yeddlerine verilen mümzâ defter mûcibince hilâf-ı şer'-i şerîf ve bi-gayr-ı hakk cebren ahz u kabz eyledikleri akçe ve eşyâları alıverilip icrâ-yı hakk olunmak bâbında hüküm ricâ eyledikleri ecilden, mahallinde şer’ile görülmek ... için yazılmıştır.

fî evâsıt-ı Z[ilhicce], se[ne] 1123

\section{Belge 19 (Ev.d. 45167)}

hatt-ı hümâyun, telhis, ikili arz, sevk, buyrultu, ilam, derkenâr, arzıhâl ve

$$
\begin{gathered}
\text { kâtip notundan oluşan } \\
\text { vakıf defteri } \\
\text { [I: iki defterdârın arzı] }
\end{gathered}
$$

\section{Arz-ı bendeleri budur ki}

Bağdâd-ı bihişt-âbâd eyâletinde vâkı İmam Ali ve İmam Hüseyin ve İmam Abbas rıdvânallahuteâlâaleyhimecma în hazretlerinin evkaf-ı şerîfelerine bundan akdem mütevelli olanlar reâyâ-yı vakfı himâyet ü sıyânet etmeyip, ve Bağdad vâlisi olanlar erbâb-ı vezâifin vazîfelerini ekl ve taaddilerinden harâba yüz tutmakla, vakf-ı mezbûr Dârüssaade ağası nezâretine ilhak ve Haremeyn Muhâsebesi'ne kayit ve serbestiyet üzere zabt u tasarruf olunup, Bağdad vâlileri vakf-ı mezbûrdan nezâret akçesi ve kapı harcı diye bir akçe ve bir habbe almayıp, ve hoş-âmed ü karakol ağaları ve gerek nâzırı vü Âl-i Keş’âm şeyhleri ve Hille zâbitleri ve kadı ve sâir ümenâ ve ammâl tâifesi dahl ü taarruz etmeleriyle evkaf-ı mezbûrenin harâbına bâis oluyorlar diye mukaddemen mütevelli olan Ali merhûm u mağfûrun-leh Sultân Mehmed Han tâbeserâhu hazretlerinin zamân-ı meymenet-iktirânlarında Rikâb-ı Hümâyun’a ref'-i rlk’a eyledikte, Haremeyn Muhâsebesi'ne kayıt ve Dârüsaade ağası nâzır olmak 
üzere bin doksan dört târihinde hatt-ı hümâyun sâdır ve vakf-ı mezbûrun kadîmî kaydı Baş Muhâsebe'de iken defterleri Haremeyn Muhâsebesi kalemine teslim ve ba'dehu Haremeyn tarafindan muharrir kâtip ve kapıcı irsâl ü tahrîr ve doksan dokuz senesinde tahrir defteri gelip kayit ve yüz iki senesinden beri tevliyet-i merkûme her sene Dârüssaade ağası olanlar arzı ile birer kimseye tefvîz olunduğu aklâmda mukayyet bulunup, vülât-ı sâbıkın evkaf-ı mezbûre kurâ vü reâyâlarına ve mütevelli olanlarına tasallutlarından nâşî tazaccurlarına sebep olduğundan, egerçi Dârüssaade ağası nezâretine ilhak u îsâl munsaref olmamak için üç dört senede bir müstakillen tavâşî ağalarından biri mütevelli tayin ve irsâl olunur idi. Lâkin giderek birkaç seneden beri teberdârlardan bazıları zuhûr ve nice mahalle bâligan-mâ-belağ cevâiz ve kapı harcı vererek tevliyet-i merkûmeyi kendi üzerlerine alıp, hatta yüz on sekiz senesinde teberdarlardan Gergerli Hüseyin nâm kimse mütevelli olup iki sene zabt ve vakf-ı mezbûr reâyasının bi-gayr-ı-hakkın zulmen mezrû’ât ve eşyâlarını ahz ü tecrîm ve ol makule hidemât-ı mebrûrede hilâf-ı marzâ-yı ilâhî zuhûra gelen harekât-ı nâ-şâyestesinden avdeti müyesser olmayıp yine Bağdad'da fevt olmakla, vakıf reâyâsından ve "Dârüssaade ağası tarafına müntesibim" diye ahâlî-yi Bağdad vâli-yi Bağdad’a bile kemâl-i tasallutundan nâşî cem` eylediği meblağ ve eşyâdan iki senede tevsî́-i dâire ve tanzîm-i hâli için hevâ vü hevesine masraf eylediğinden mẩadâ, yüz elli kese akçeye karîb nakd ü eşyâ terk ve bu tarafa vârislerine getirildiği, ba'dehu yüz yirmi senesinden beri teberdâr elHâc Osman ile Yedekçi Ali nâm kimseler zuhûra gelip ve birkaç sene tevliyet-i mezbûre arzını açıtan alıp ve mezbûr Yedekçi Ali zikr olunan "Meşhedeyn tevliyetini fürûht ederim" diye esvaak u hânâtı gezip bey 'hel men mezîd ile mîrî mukâtaa fürûht eder gibi bir defa Cebeci çorbacılarından Hasan Çorbacı nâm kimseye ve bir defa dahi Bezirgân Ahmed Seyyâf'a, ba'dehu Harput ahâlîlerinden bir Yeniçeri neferine, ba'dehu sâbıkan Bağdad defterdârı Ömer Bey’e, senede on beşer kese akçelerin[i] alıp fürûht, ve'l-yevm mütevelli olan yine teberdârlardan olup ve tevliyet-i merkûme Dârüssaade ağası nezâretine ilhak olunduğu vakitten beri zikr olunan evkaf-ı mebrûreden ahâlî-yi Bağdad fukarâsından vezâif ü cerâyeye mutasarrıf olanların ashâbı mevcût ve hizmet-i lâzımesinde mukim olacak nice cihât-ı mahlûlâtı vâkı oldukça mütevelli olanlar ebnâ-yı hasîs olmak takrîbi ile bu makule cihâtı Dârüssaade ağaları hizmetinde olan teberdârlara olmak üzere arzların[1] verip, bu vechle nice fukarâ vu zu'afânın tazaccur u inkisârlarına ve şart-ı vâkıfa mugâyir nice hidemât-ı vakfın iptâline bâis ve mütevelli olanlar tamaci hâmlarından ve bu tarafta ziyâde akçe masraf eylediklerinden nâşî mahallinde mukâtaatın ekserini Yeniçeri ve sâir erâzil-i eşhâsa fürûht ve onlar dahi reâyâ-yı evkaf üzerine musallat ve rencîde vü taciz ü taaddilerinden ahvâlleri muztarr ve bi'l-cümle iklîmi âhara firâr etmek mertebelerine varmıştır; diye vukuf-ı tâmmı olan ahâlî-yi 
Bağdad'dan bî-garez kimseler ve ol taraftan tevârüd eden mevsûku'l-kelâm Devlet-i Aliyye ricâlinden niceleri takrir ve reâyâ-yı vakf-ı şerîf üzerlerinden bu zulüm ve taaddi vü tecâvüzün def' ü ref'i ihrâz-ı müsevvebât-ı cezîle olduğun[u] haber verirler. Evkaf-ı merkûme mukaddemen kimsenin nezâretinde değil iken, Bağdad vâlisi ve kadısı olanlar tevliyet-i merkumeyi bazı kimselere tefvîz, ve vâli vü mütevelli olanlar reâyâyı himâyet etmeyip rencîde vü taciz eyledikleri mukaddemen arzıhâl ile îlâm olundukta, evkaf-ı mezbûre Dârüssaade ağaları nezâretine ilhak olunması mukaddemen Bağdad vâlileri nezâretinde iken vâkı olan mefâsidi def' ve reâyâ-yı vakfı himâyet ü sıyânet için iken, Dârüssaade ağası nezâretine ilhak olundukta, reâyâ-yı vakfa cevr ü taaddi zikr olunduğu üzere evvelkinin birkaç [mu]z[âa' afı olduğu hadd-i tevâtürde olmakla, mukaddemen mütevellinin arzıhâli vâli-yi Bağdad olanlardan neş'et eden mefâsidi def' için olmayıp, ancak vakf-ı merkumu Haremeyn'e kaydettirmek için tertip olunmuş sûret-i hakktan bir mukaddime-i masnû’a olduğu zâhir olup, husûsen Dârüssaade ağası olanlar tarafından bu cânipte mütevelli olanlar dahi tevliyet-i mezbûreyi kendilere tefvîz ettirince cevâiz ve kapı harcı nâmıyla nice akçeler verip, mahalline vardıklarında cerr-i nef' ve celb-i menfaatleri için vaz' u hareket, ve kelâmlarında kendilere bi'l-vâsıta taraf-ı Saltanat-ı Seniyye-i mülûkâneye intisâb ve ihtisâs ünvânını verip, ve bu şöhret-i kâzibe ile reâyâ-yı vakf üzerine değil vâli-yi Bağdad olanlara dahi musallat ve bir iki sene içinde vakf-ı şerîf reâyâsından birkaç yüz kese akçe celb ü bir müddet dahi tedâriği görülmeyip ve nizâmı verilmediği sûrette reâyâ bi'l-cümle perîşân ve evkaf-ı merkume muattal u harâb olacağı zâhir ü âşikâr olup, sûret-i müstahseneye ifrâğı mühimm ü muktezâ olmağın, evkaf-ı merkume Dârüssaade ağaları nezâretlerinden ref` ve defâtir ü evrâkı Haremeyn Muhâsebesi’nden ahz u kadîmî üzere Baş Muhâsebe'ye kayıt ve teslim ve be-her sene Bağdad vâlileri bi'n-nefs umûr-ı tevliyeti kendiler görüp senesi tekmîlinde îrâdı ve şart-ı vâkıf üzere masârıfı her ne ki vâkı olmuş ise marifet-i şer'ile defter eyleyip, defter-i merkumu Der-i Devlet-medâra irsâl ve vezîriazam bulunanların vesâtetleriyle Rikâb-ı Hümâyun-ı cihân-dârîye arz u telhîs olunup, hasbetenlillah ve taleben li-merzâtillahi teâlâ nazar-ı hümâyun-i cihân-bânî taalluk edip, îrâd u masârıfi makbûl-i hümâyun-i mülûkâne olduktan sonra teberrüken ü teyemmünen mahalline kayıt olunmak üzere hatt-ı hümâyun-ı mevhibet-makrûn keşîde buyurulup, ve reâyâ-yı evkaf-ı merkumenin küllî ve cüzî̀ umûrları vâkı oldukça bizzat ahvalleri Rikâb-ı Hümâyun’a arz ve malum-ı hümâyun-ı cihân-bânî olup, iktızâsına göre ahvalleri görülmek şartıyla tevliyeti merkume bin yüz yirmi yedi senesinden üç sene bir tahvil ile hâlen Bağdad vâlisi vezîr-i mükerrem izzetlü Hasan Paşa hazretlerine tefvîz olunup, vezîr-i müşârunileyh dahi emr-i tevliyette vâkıfın şart eylediği ile kanaat eyleyip, kapı harcı ve hoş-âmed ve karakol ağaları ve gümrük nâzırı ve Âl-i Keş’âm şeyhleri 
ve Hille zâbitleri ve kadı vü sâir ümenâ vü ammâl tâifesi vechen mine’l-vücûh ve sebeben mine'l-esbâb dahl u taarruz eylememek üzere bu hizmet-i celîleyi kendine bâis-i saadet-i Dâreyn bilip, kemâl-i adl ü insâf ile hareket ve bir ferdi rencîde vü taciz etmeyip, şart-ı vâkıfı icrâ ederek bir senede mecmû̉u îrâd ü masârıfı malum olmak için ziyâde taharrî vü ihtimâm ile işbu yüz yirmi yedi senesinde gerek îrâd ü gerek masârıfı gereği gibi zabıt ve defter ve arz u îlâm eylemek, ve "tevliyet-i merkume bana tefviz olunmuştur" diye reâyâ-yı vakfı mukaddemen nezâret eden Bağdad vâlileri ve sonra mütevelli olan teberdârlar ve sâirleri misillü tama’a düşüp cevr ü eziyet ile perâkende vü perîşân etmekten ziyâde hazer edip, nizâm-ı ahvalleri ile müreffehü'l-bâl olmalarına takayyüd-i tâm ve dikkat ü ihtimâm ve vâkı olan mahlûlât-ı vezâifi dahi mahallinde mahall ü müstehak olanlara arz u îlâm eyleyip, şefaat ve ricâ zımnında nâ-müstehak olan kimselere verilmemesine sa'y-i mâ-lâ-kelâm olunmak üzere bu şurût u kuyûd-ı merguba fîmâ-ba'd ilâ-mâşallah-i teâlâ düstûrü’l-amel tutulup, Baş Muhâsebe'ye kayıt ve minvâl-i meşrûh üzere berât-ı âlî ve emr-i şerîfi tahrir olunmak bâbında emr ü fermân devletlü saadetlü sultânım hazretlerinindir.

[II: sadâret kethüdâsından sevk] MAHALLİ GÖRÜLE!

[III: sadrazam buyrultusu] İZZETLÜ DEFTERDÂR EFENDİ MUKADDEM U MUAHHAR KUYÛDÂTI GÖRÜP VUKUFU OLANLARDAN SUAL EDIP ÎLÂM EYLEYE DIYE BUYURULDU!

[Iv: defterdar îlâmı ]

[Iv.1. defterdar îlâmı: hatt-ı hümâyun alıntısı]

Kaimmakam vezir İbrâhim Paşa! Telhîsin üzere Haremeyn-i Şerîfeyn evkafına ilhak edip muhâsebesine kaydedip Dârüssaade ağası nâzır olmak hükmü veresin!

6 [Ramaza]n se[ne 10]94

Kaimmakam vezir İbrâhim Paşa! Sorup sual edip bir hoşça hakikat üzere arz edip Haremeyn Vakfi'na ilhak olunmada bir beis, mahzur var mıdır yok mudur, arz edesin!

[III.2. defterdar îlâmı: sadâret kaymakamının arzı alıntısı]

Arz-ı bende-i bî-mikdâr budur ki 
Vakf-ı mezbûr zulm-i taaddîden emîn olmamakla, kimse dest-dirâz etmemek için Dârüssaade ağası nezâretine ve Haremeyn-i Şerîfeyn Muhâsebesi’ne kaydolunmak bâbında fermân şevketlü ve kerâmetlü pâdiş̧âhımındır.

[IV.3. defterdar îlâmı: mütevelli arzıhâlinden alıntı]

Şevketlü ve kudretlü ve azametlü ve âmme-i ibâdullaha merhametlü Pâdişâhım hazretlerinin mübârek Rikâb-ı Hümâyun'larına arzıhâl-i fakir budur ki Bu kulları Bağdad'da Meşhedeyni'ş-Şeriffeyn-i hazret-i İmam Ali keremallahuveche hazretlerinin evkafına hatt-ı hümâyun-ı şevket-makrûn ile mütevellisi olup, vâli-yi Bağdad olan Abdi Paşa kulları zamânında mütevelli olup, şevketlü pâdişâhımızın hatt-ı hümâyunları semeresiyle bin dörtyüz kuruş îrâdı var iken şimdi onbin kuruşa kadar bâliğ olup mürtezikasının vaziffeleri tamam verilip matbah-ı şerîfleri kâlevvel işlenir iken, hâlen vâli-yi Bağdad olan İbrâhim Paşa hazretlerinin taaddîsinden yine harâba yüz tutup ve fukarâya verilecek vezâiften ikibin kuruş kendisi ve beşyüz kuruş kapı harcı diye alıp ve fukarânın vazîfesi nısfiyet üzere verilmek üzere elime mühürlü ve fermanlı defter verip ve paşa olalı bin doksan iki ve doksan üç ve doksan dört senelerinde vakf-ı şerîften on dokuz kese alıp ve bu kulların[1] "katl ederim" diye tahvîf edip, üzerime yüz elli atlı gönderip "sen paşalar vakfa karışmasın diye hatt-ı şerîf çıkardın, bakalım sana hatt-ı şerîfin nef'i olur mu" diye cebren ü kahren otuz kese dahi bu kullarından alıp, bir vechle halâs mümkün olmayıp, hacc-ı şerîf niyetine izin alıp bu tarafa firâr etmeğin ve hacc-ı şerîfe gitmeğe izni bile Şâtır Ahmed Ağa kulları alıverip ve ben gittikten sonra tevliyete karındaşım kulların[ı] ... en ${ }^{69}$ mütevelli edip ben gittikten beri vakf-ı şeriften ne aldığı malum değildir. Lillah ve resûluhu hâlime merhamet, elimizde olan hatt-ı hümâyun-ı saadetmakrûn ve kendi mührüyle olan deftere nazar buyurulup, bu vakf-ı şerîfi mezbûrun elinden halâs u vakf-ı şerîften aldığı on dokuz kese ve bu kullarından aldığı otuz kese şer’ile tahsil, ve bu akçelerimizin verildiğini hâlen bu tarafta Bağdad defterdârı olan Mehmed Efendi ve Belgrad mollası nâibi Abdullah Efendi bilip, bu akçe şer'ile tahsil ve ba'de'l-yevm vakf-ı mezbûr Dârüssaade ağası kullarının nezâretlerine ilhak u Haremeyn-i Şerîfeyn Muhâsebesi'ne kayıt ve vakf-ı mezbûr mefrûzü'l-kalem u maktû’u'l-kadem serbest olup serbestiyet üzere zabt u tasarruf olunup ve ba'de'l-yevm vâli-yi Bağdad olanlar vakf-ı mezbûrdan nezâret akçesi ve kapı harcı diye bir akçe ve bir habbe almayıp, hoşâmed ağaları ve karakol ağaları ve gerek nâzırı ve Âl-i Keş’âm şeyhleri ve Hille zâbitleri ve kadı vü sâir ümenâ vü ammâl tâifesi min-ba'd dahl ü taarruz eylememek üzere hatt-ı şerîf sadaka vü ihsân buyurulup vakf bi'l-külliye

69 Dağılan mürekkepten dolayı sözcüğün başı okunamıyor. 
şevketlü ve kudretlü pâdişâhımın ihyâsı olup fukarânın hayır-duâların almak bâbında ferman şevketlü ve kudretlü pâdişâhım hazretlerinindir. bende Ali

[IV.4. defterdar îlâmı: geçmiş bir îlâmdan alıntı]

Bağdâd-ı bihişt-âbâdda vâkı Meşhedeyni'ş-Şerîfeyn-i hazret-i İmam Ali keremallahuveche hazretlerinin evkaf-ı şerifelerine hatt-ı hümâyun-i devletmakrûn ile mütevelli olan Ali, Belgrad sahrâsında Rikâb-ı Hümâyun’a arzıhâl sunup ... ${ }^{70}$ inâyet ricâ etmeğin, vakf-ı mezbûr zulm-i taaddîden emîn olmamakla kimse dest-dirâz etmemek için Dârüssaadeti'ş-Şêrîfe ağası nezâretine ve Haremeyni'ş-Şerîfeyn Muhâsebesi'ne kaydolunmak bâbında Pâye-i Serîr-i A'lầya arz u telhîs olundukta, sâdır olan hatt-ı hümâyun-ı saadetmakrûn mûcibince "vakf-ı mezbûr Dârüssaade ağası nezâretine ilhak ve Haremeyni'ş-Şerîfeyn Muhâsebesi'ne kaydoluna" diye bin doksan dört senesi Ramazânı’nın on ikinci gününde fermân-ı âlişân sâdır olmağın, vech-i meşrûh üzere vakf-ı mezbûr bâlâda zikr olunduğu şurût u kuyûd ile mefrûzü'l-kalem ve maktû'u'l-kadem serbest olup serbestiyet üzere Dârüssaade ağası nezâretine ilhak ve Haremeyn-i Şerîfeyn Muhâsebesi'ne vârid olan hatt-ı hümâyun-i saadet-makrûn mûcibince sâdır olan fermân-ı âlişân ile kayd olup Dârüssaade ağası nezâretinde olmakla, Dârüssaadeti'ş-Şerîfe ağası olup Haremeyn-i Muhteremeyn evkafı nâzırı olan Yusuf Ağa dâmeuluvvihu Ordu-yı Hümâyun'a arz edip hatt-ı hümâyun-ı saadet-makrun mûcibince sâdır olan fermân-ı âlişân ile nezâretlerine ilhak olmakla, zikr olunan Meşhedeyn-i Şerîfeyn-i hazret-i İmam Ali keremallahuveche hazretlerinin evkafı tevliyeti vazîfe-i muayyene vü hatt-ı hümâyun-ı saadet-makrûn ile mûmâileyh Ali’nin üzerinde olup vakf-ı şerife istikamet ile hizmet edip ve mücidd ü sầi olduğu ecilden bin doksan dört senesi Ramazânı'nın on beşinci gününde geri zabtetmek üzere bervech-i te'bîd tevcih olunup müceddeden berât-ı âlişân verilmek ricâsını îlâm eylemeğin, mûcibince tevcih olunmak bâbında fermân-ı âlişân sâdır olmakla, vakf-ı mezbûrun tevliyeti vazîfe-i muayyenesiyle sene-i mezbûre Ramazânı'nın on beşinci gününden geri zabtetmek üzere ber vech-i te'bîd tevcih olunmağın, vakf-ı mezbûra bundan akdem mütevelli olup zabtedenler ne vechle mütevelli olup zabt u rabt ve vâkı olan cüz'î vü küllî mahsûlât ü rüsûmâtta ahz ü kabz edegelmişler ise mûmâileyh Ali zîdekadruhu dahi ol minvâl üzere zabt u rabt ve vâkı olan cüz'î vü küllî mahsûlât ü rüsûmât vakf-ı şerîf için ahz ü kabz eyleyip, seneyesine muhâsebesin görülmek şartıyla vakf-ı şerîf mefrûzüll-kalem ve maktû̉ul-kadem serbest olmakla Bağdad vâlileri tarafindan nezâret akçesi

70 Mütevelli Ali’nin yukarıdaki dilekçesinin alıntılanması. 
ve kapı harcı nâmıyla dahl ü taarruz olunmayıp hoş-âmed ağaları ve karakol ağaları ve gerek nâzırları ve Âl-i Keş’âm şeyhleri ve Hille zâbitleri vü kadıları ve sâir ümenâ vü ammâl tâifesi min-ba'd dahl ü taarruz eylemeyip serbestiyet üzere vakfın mütevellisi zabt eylemek üzere müceddeden berât-ı âlişân için tezkire verildiği Haremeyn-i Şerîfeyn Muhâsebesi’nde mastûrdur.

fî 16 [Ramaza]n, se[ne] 1094

[IV.5.]

Evkaf-ı mezbûre nâzırı olan Yusuf Ağa, Dîvân-ı Hümâyun’a arz gönderip taht-ı nezâretlerinde olmakla Bağdâd-ı bihişt-âbâd eyâletinde vâkı hazret-i İmam Ali vü İmam Hüseyin ü İmam Abbas rıdvânallahuteâlâaleyhimecma’în hazretlerinin evkaf-ı şerîflerinden olup hazret-i İmam Ali vü İmam Hüseyin kasabalarında ve Hille vü Mehrûd ü Mendelcin ü Şehribân ü Hâd ü Kebçe nâhiyelerinde ve tevâbi'inde ve merhûm ü mağfûrun-leh Sultan Süleyman Han tâbeserâhu evkafi olan şatt ${ }^{71}-1$ Firat'tan hazret-i İmam Hüseyin kasabasına gelince üzerinde olan kurâ vü mezâri’ ü bağ ü bahçe vü eşcâr-ı hurma ve sâirleri bundan akdem dokuzyüz seksen üç târihinde tahrîr ve ma'mûlü’n-bih defter olunup ol zamândan bu âna değin tahrir olunmadığından ve vakfın ekser yerlerin[i] bazı kimseler kendilerine temlîk ü kadîmî tahrîr defterlerinde yok iken meşrûta edip "meşrûtumuzdur" diye hilâf-ı defter ü mugâyır-ı şart-ı vâkıf zabt u tasarruf edip, vakf-ı şerîfe küllî gadr ü nice yerleri ketm olunup muhtell ü müşevveş olmakla, atıyk tahrir defteri mûcibince İmam Ali vü İmam Hüseyin ü İmam Abbas hazretlerinin evkafları olan İmam Ali vü İmam Hüseyin kasabalarında ve Hille vü Mehrûd ü Mendelcin ü Şehribân ü Hâd ü Kebçe nâhiyelerinde ve tevâbi'i hudud dâhilinde vâkı kurâ vü mezâri' ü bağ ü bahçe ve eşcâr-ı hurma ve dekâkîn ü boya-hâne ve kasap-hâne ve kapân ü sûku'l-gazl ü hamam ve beytülmâl-i âmme vü hassa vü ba'de't-tahrîr vakfin hudûdu dâhilinde ihdâs olan musakkafât $u$ imârât ve sâir cüzî vü küllî her ne ise tahrîr ve ma’mûlü’n-bih defter olunup, evkaf-ı mezbûrenin mezâri' ve bağ ü eşcâr-ı hurma ve imârât u musakkafâtından cüz'î vü küllî nesnesi ketm olunmayıp, hâric ez-defter kalmayıp, bir hoşça tahrir ve ma’mûlü’n-bih defter olunmak üzere Haremeyn-i Şerîfeyn Muhâsebesi kalfalarından Mehmed Kalfa muharrir ve mütevelli-yi vakıf Ali Ağa marifetiyle ve Dergâh-ı Âlî bevvâblarından Mehmed mübâşir tayin buyurulup, mezbûrların marifet [ü] mübâşeretiyle vakf-ı mezbûr kemâl mertebe takayyüd ü ihtimâm üzere tahrir ve defter ettirilip tahrirlerine âhardan bir ferd dahl ü taarruz ve mâni' ü müzâhim olmayıp bir hoş nizam verilmek üzere Bağdad Muhâfazası'nda olan vezîr-i mükerrem

$71 \quad$ Misspelled here as "şâd." 
hazretlerine ve Bağdad mollası efendiye hitâben müekked emr-i şerîf-i âlişân verilmek ricâsını îlâm eylemeğin, "mûcebince müekked hüküm verile" diye bin doksan yedi senesi Rebîülâhiri’nin on dördüncü gününde nâzır-ı vakfın arzı ve sâdır olan fermân-ı âlî mûcibince vech-i meşrûh üzere müceddeden tahrîri için emr-i şerîf verildiği dahi mastûrdur.

fî 14 Z[ilhicce], se[ne] 1097

[Iv.6.]

Muharrir-i mezbûrun tahrir defteri gelip ma'mûlü'n-bih olunmakla, Defterhâne-i Âmire'ye kayit ve memhûr sûreti bin doksan dokuz senesi târihiyle müverrah fermân-ı âlî mûcibince düstûrü'l-amel olmak üzere Haremeyn-i Şerîfeyn Muhâsebesi'nde hifz olunmuştur.

Mezbûr Ali tevliyet-i mezbûra bin yüz iki senesine gelince mutasarnf iken, sene-i mezbûrede üzerinden ref' ve âhara tevcih olunup, ol târihten beri beher-sene nâzır-ı vakf marifetiyle birer kimseye tevcih olunagelmeğin, bin yüz yirmi altı senesi Martı ibtidâsından zabt etmek üzere hâlen nâzır-ı vakf ve Dârüssaadeti'ş-Şerîfe ağası saadetlü Mehmed Ağa hazretlerinin arzı mûcibince bâ-fermân-ı âlî Hacı Hasan nâm kimseye tevcih olunup hâlen mezbûrun üzerinde olduğu Haremeyn-i Şerîfeyn Muhâsebesi'nde mastûr ü mukayyettir.

$$
\begin{array}{r}
\text { [v. sadâret kethüdâsınca yeniden sevk] } \\
\text { KADÎMDEN EVKAF-I MERKÛMENIN KAYDI NE VECHLEDIR, } \\
\text { DEFTERHÂNE'DEN TAFSîL ÜZERE DER-KENÂR [OLUNA]! } \\
\text {... VAKIFTIR }
\end{array}
$$

[VI. Defterhâne-i Âmire'den derkenâr]

der livâ-i $[$ Bağ $]$ dad

an Evkaf-ı hazret-i Imam Ali ve İmam Hüseyin ve İmam Abbas radiallahuteâlâanhum

Meşhed-i şerîf-i hazret-i İmam Ali keremallahuveche

neferen

Hâsıl an mahsûl-i icâre-i hammâm-ı kadîm, fî Sene: kuruş: 190

Yekûn ma'a gayrıha, fì Sene: kuruş: 2582

fî̀ro an evkaf

[VII. sadâret kethüdâsinca ikinci yeniden sevk] KÜÇÜK EVKAF'TAN KADÎMÎ KAYDI DER-KENÂR OLUNA! 
[vıII. Küçük Evkaf/Muhâsebe Kalemi’nden derkenâr]

Küçük Evkaf Muhâsebesinde kaydıyoktur. Ferman devletlü sultânım hazretlerinindir.

fî̀o [Ramaza]n, se[ne] 1126

[Küçük Evkaf Muhâsebecisinin imzâsı]

[IX. sadâret kethüdâsinca üçüncü yeniden sevk] ANADOLU MUHÂSEBESİNDEN DER-KENÂR OLUNA! BAŞ MUHÂSEBE['DEN] DER-KENÂR [OLUNA]!

[x. Baş Muhâsebe Kalemi’nden der-kenâr]

Bağdad'da vâkı Meşhedeyn-i Şerîfeyn mevkufesi Baş Muhâsebe [de] mukayyet iken, bâ-fermân-ı âlı bin doksan dört senesinde Dârüssaade ağası nezâretinde olmak için defterleri Haremeyn-i Şerîfeyn Muhâsebesi Kalemine verilmiştir. Ferman saadetlü sultânım hazretlerinindir.

fì 1 [Ramaza]n, se[ne 1$] 126$

[Baş Muhâsebecinin imzâsı ]

[XI. sadâret kethüdâsınca dördüncü yeniden sevk] KIMIN NEZÂRETINDE İDİ? BAŞ MUHÂSEBE'[DEN] DER-KENÂR [OLUNA]!

[XII. Baş Muhâsebe Kalemi'nden ikinci der-kenâr]

Mukaddemen kimsenin nezâretinde olmayıp, ? tevliyeti Bağdad vâlisi arzı ve kadısı arzı ile ve arzıhâl ile dahi tevcih olunageldiği defterde mastûrdur. Ferman saadetlü sultânım hazretlerinindir.

fìn Ramaza[n], se[ne] 1126

[Baş Muhâsebecinin imzâsı]

[XIII. Sadrazam telhisi]

Arz-ı bende-i bî-mikdâr budur ki, şevketlü inâyetlü kerâmetlü kudretlü Pâdişâhım!

Bağdâd'da vâkı Meşhedeyn-i Şerîfeyn evkaf ve tevliyetine müteallık defterdâr efendi kullarının mufassal arzıdır. Manzûr-ı hümâyun-i hüsrevânîleri buyuruldukta, telhîs-i merkumda zikr olunduğu üzere tevliyet-i merkume Haremeyn Kalemi’nden refc, ve yine kadîmî üzere Baş Muhâsebe Kalemi’ne 
kayıt, ve şurûtuyla Bağdad vâlilerine tefvîz olunmak üzere mübârek hatt-ı hümâyun-i inâyet-makrûnları ihsânıyla evkaf-ı mezbûre ihyâ buyurulmak bâbında emr ü fermân şevketlü inayetlü celâletlü mehâbetlü efendim pâdişâhındır.

[xIv. Hatt-ı Hümâyun]

Vakf-ışerîfin imârıve ibâdullahın refâh-i hâlleriiçinvakf-ımezbûrDârüssaade ağalarının nezâretinden ref' ve Haremeyn Muhâsebesinden kaydı terkıyn olunup kadîmî üzere Baş Muhâsebe'ye kaydoluna! Ve fîmâ-ba'd işbu şurût u nizâm mûcibince amel olunup hilâfindan hazer oluna!

[xv. Sadrazam buyrultusu]

$S A H H$.

SÂDIR OLAN HATT-I HÜMÂYUN-I ŞEVKET-MAKRÛN MÛCİBINCE NEZÂRETTEN REF', VE HAREMEYN MUHÂSEBESI'NDEN KAYDI TERKIYN, VE DEFTERLERİ AHZ, VE KADÎMÎ ÜZERE BAŞ MUHÂSEBE'YE KAYIT VE TESLİM, VE İ̧̧BU ŞURÛT FÎMÂ-BA'D DÜSTÛRÜ'L-AMEL TUTULUP BERAT VERİLE DIYYE BUYURULDU!

27 [Ramaza]n, se[ne 1]126

[XVI. Sadâretten sevk] HAREMEYN KALEMI'NE KAIMME VERİLE!

[XvII. kâtip notu] Haremeyni'ş-Şerîfeyn Muhâsebesi'ne kaime verilmiştir. fî 6 [Şevva]L, se[ne 1]126

\author{
Belge 2o (EV.HMH.d. o2584) \\ muhasebe defteri \\ Müsvedde-i Meşhedeynişs-Şerîfeteyn \\ an vâcib-i sene 1133
}

[I]

MUHÂSEBE-i

mahsûlât ü ihrâcât-ı Evkaf-ı Şerîf-i Meşhedeyni'ş-Şerîfeteyn der Bağdâd-ı bihiştâbâd, an tahvîl-i vezîr-i mükerrem müşîr-i müfahham hazret-i Hasan Paşa yesserullahumâyeşâ muhâfız-ı Bağdâd hâlen, ibtidâ-yi Eylül fî Zilkade sene 1133 ilâ gâye-i sene-i minhu: 
ASL-1 MAL

fî sene-i kâmile maa bakiye-i muhâsebe-i sene- mâziye:

$17155^{1 / 2}$ esedî guruş

AN-AKÇE-i

der kese-i makaam-ı kaabız-ı Vakıf an Muhâsebe-i Evvel an Zilkade-i sene-i 1133 baakî mânde ve hâlen der în muhâsebe îrâd şüde:

222 3/4 esedî guruş

'ANİ'L-MAHS ÛLÂT-1

mezkûrîn:

$1693^{3 / 4}$ esedî guruş

'AN

icârât u rüsûmât-ı mezkûrîn:

11099 1⁄2 esedî guruş

'AN MAHSÛL-i

mukâta'ât-ı Vakıf der kasaba-i hazret-i İmam Ali raziallahuteâlâanh an ibtidâ-i Eylül / Zilkade-i sene 133:

5375 guruş fî sene

MINHA

mâ-inkıtâ'-i züvvâr-ı Acem kesr şüde

$-1251 \frac{1 / 2}{2}$ guruş

= 4123 1/2 guruş el-baakî mahsûb

'AN MAHSÛ L-i

resm-i kubûrât u nüzûrât der âsitâne-i hazret-i İmam-ı müşârunileyh fî̀t-târîhi'l-mezbûre:

35 o guruş fî sene.

'AN MAHSÛL-i

resm-i nüzûrât der âsitâne-i hazret-i İmam Hüseyin raziallahuteâlâanh:

220 guruş fî sene.

'AN MAHSÛL-i

resm-i kubûrât der âsitâne-i hazret-i İmam Hüseyin raziallahuanh fî̀t-târîhi'l-mezbûr:

125 guruş fî sene. 
'AN MAHSÛL-i

icâre-i hân-ı Vakıf der kasaba-i hazret-i İmam-ı müşârunileyh fî̀t-târîhi'l-mezbûr:

2950 guruş fî sene — minhâ 1000 guruş, el-baakî = $195^{\circ}$

'AN MAHSÛL-i

icâre-i nısf-ı boya-hâne-i Vakıf der kasaba-i hazret-i İmam-ı müşârunileyh fî̀t-târîhi'l-mezbûre:

525 guruş fî sene.

'AN MAHSÛL-i

icâre-i ma’sara-hâne-i Vakıf der kasaba-i hazret-i İmam-ı müşârunileyh fî̀t-târîhi'l-mezbûre:

1050 guruş fî sene.

'AN MAHSÛL-i

icâre-i kasap-hâne-i Vakıf der kasaba-i hazret-i müşârunileyh fî̀t-târîhi'l-mezbûre:

1000 guruş fî sene.

'AN MAHSÛL-i

icâre-i tesbîh-sâzân der kasaba-i hazret-i müşârunileyh

fî̀t-târîhi'l-mezbûre:

146o guruş fî sene — minhâ 10oo, el-baakî = 46o

'AN MAHSÛL-i

icâre-i ?-i kefen der kasaba-i hazret-i İmam-ı müşârunileyh fî̀t-târîhi'l-mezkûr:

25 o guruş fî̀ sene - minhâ 2oo, el-baakî = $5^{\circ}$

'AN MAHSÛL-i

icâre-i bâzâr-ı Taşlık der kasaba-i hazret-i müşârunileyh

fî̀t-târîhi'l-mezbûre:

85 guruş fî̀ sene.

'AN MAHSÛL-i

resm-i arûsâne der kasaba-i hazret-i İmam-ı müşârunileyh

fî̀t-târîhi'l-mezbûre:

go guruş fî̀ sene. 
'AN MAHSÛL-i

me’kele-i mütevelli-yi esnâf der kasaba-i mezbûre:

400 guruş fî sene.

'AN MAHSÛL-i

icâre-i subaşılık der kasaba-i mezbûre fî̀t-târîhi'l-mezbûre:

100 guruş fî̀ sene.

'AN MAHSÛL-i

deştbân-ı merta'-ı camış der kasaba-i mezbûre:

112 guruş fî sene.

'AN MAHSÛL-I

icâre-i dekâkîn ü hânehâ der kasaba-i mezbûre:

220 1/2 guruş fî̀ sene.

'AN MAHSÛ L-İ

icâre-i dekâkîn ü hânehâ der kasaba-i Hille fî̀t-târîh-i m:

11 guruş fî sene.

'AN MAHSÛL-İ

icâre-i dekâkîn ü âsiyâb der şehr-i Haleb fî̀t-târîhi'l-mezbûr:

$37^{1 / 2}$ guruş fî sene.

'AN MAHSÛL-İ

icâre-i hamâm u nahl-i hurmâ vü mezraa-i Mendelcin:

40 guruş fî̀ sene.

'AN MAHSÛL-İ

meşîhat-i kurâ-ı Vakıf der kasaba-i Hille fî̀t-târîh-i m:

6 o guruş fî̀ sene.

'AN MAHSÛL-İ

mâhiyâne ve ıydiye-i kurâ-ı Vakıf der kasaba-i Hille

fî̀t-târîhi'l-mezbûre:

9o guruş fî sene.

'AN MAHSÛL-İ

maktûât u mezrûât $\mathrm{u}$ gayrıhu: 
4963 1⁄2 guruş fî̀ sene.

'AN MAHSÛL-İ

haffâr-ı bedel-i hums der kurâ-ı kasaba-i hazret-i İmam Hüseyin raziallahuanh an ibtidâ-i Eylül ve Zilkade-i sene 1133: 655 guruş fî sene.

'AN MAHSÛL-İ

icâre-i semek der civâ(r)-1 kasaba-i hazret-i İmam-ı müşârunileyh fî̀t-târîhi'l-mezkûre:

100 guruş fî sene.

'AN MAHSÛL-I

akçe-i bedel-i hafr-ı kurâ-i Vakıf der Hille fîtt-târîh-i m:

250 guruş fî sene.

'AN MAHSÛL-İ

nehr-i Mehâvîl-eyn fî̀t-târîhi'l-mezbûre:

199 1⁄2 guruş fî̀ sene.

'AN MAHSÛ L-i

icâre-i ? ? ma’a nahl-i hurma der nehr-i Ümrân

fî̀t-târîhi'l-mezbûr:

267 1/2 guruş fî sene.

'AN MAHSÛL-i

beytü'l-mâl-i A'câm fî̀t-târîhi'l-mezbûre:

25 guruş fî sene.

'AN MAHSÛL-i

akçe-i müjdegâ[ne]-i Kul fî̀t-târîhi'l-mezbûre:

1 o guruş fî sene.

'AN MAHSÛL-i

ser-dağar-ı maktû̉ât-ı enhâr-ı Hüseyniye fî̀t-târîhi'l-mezbûre: 1135 guruş fî sene.

'AN MAHSÛL-i

ser-dağar-ı maktû’ât-ı kurâ-ı Vakıf der Hille fî̀t-târîh-i m:

265 guruş fî sene. 
'AN MAHSÛL-i

tahmîn-i mezrû’ât-ı bâğât der kasaba-i hazret-i İmam Hüseyin 200 guruş fî sene.

'AN MAHSÛL-i

ruusü’l-riyâcîl der mezâr[i' u] kurâ-ı Hüseyniye fî̀t-târîh-i m: 225 guruş fî̀ sene.

'AN MAHSÛL-i

hurma der kasaba-i Şefâte fî̀t-târîhi'l-mezbûre:

40 guruş fî sene.

'AN MAHSÛL-i

hurma-i kurâ-ı Vakf-ı şerîf der kasaba-i Hille fî̀t-târîh-i m: 1540 guruş fî̀ sene.

'AN MAHSÛL-i

icâre-i dekâkîn-i cedîd [ve] kahve-hâne fî̀t-târîhi'l-mezbûre:

$33^{1 / 2}$ guruş fî̀ sene

\section{'ANI'L-îRÂD}

'an enhâr-ı Hüseyniye der kurâ-ı Vakıf der Hille:

1525 dağar hınta vu şaîr bâ vezn-i Hillâvî

'AN BEHÂ-yl

hınta ve şaîr-i Hüseyniye:

1155 dağar

955 dağar hinta

2oo dağar şa'ir

'AN KURÂ-I VAKIF

hınta ve şaîr der Hille:

370 dağar

$$
\begin{aligned}
& 215 \text { dağar hınta } \\
& 155 \text { dağar şaîr }
\end{aligned}
$$

MINHA

sarf şüde berây-ı ashâb-ı cerâyehâ ve mütekaaidîn ve gayrıhu: $1005^{1 / 2}$ aded dağar hinta vü şaîr fî sene

446 guruş / 960 dağar hınta

423 guruş / 45 1⁄2 dağar şaîr 
VUZİA MIN ZÂLIK

12710 esedî guruş

EL-VAZÂİF-i

huddâm-ı vakf u mütekaaidîn-i duâ-gûyân ve gayrıhu der âsitâne-i hazret-i İmam Ali ve İmam Hüseyin ve İmam Abbas rıdvânallahuteâlâal eyhimilmecmâîn:

7204 guruş fî sene $=$ yevm 3602 [akçe]

be-her akçe: 2 guruş fî sene

'AN I'L-İHRÂCÂT

ma’a mühimmât-ı mezkûrîn:

5506 aded esedî guruş

'AN

ihrâcât-ı sâire:

3971 aded esedî guruş

BE-CİHET-i

masârif-i imâret-i âsitâne-i hazret-i İmam Ali raziallahuteâlâanh:

199 guruş fî sene

BE-CIHET-i

masârif-i imâret-i âsitâne-i hazret-i İmam Hüseyin raziallahuteâlâanh:

333 guruş fî sene

BE-CİHET-i

bahâ-i hıla' berây-ı mültezimân ma’a şüyûh-ı esnâf ber-mûcib-i mu’tâd-ı kadîm:

140 guruş fî sene

BE-CİHET-i

bahâ-i şem’-i asel berây-ı âsitâne-i hazret-i İmam Ali raziyallahu:

135 guruş fî sene 
BE-CIHET-i

bahâ-i şem'-i asel berây-ı âsitâne-i hazret-i İmam Hüseyin raziyallahuteâlâanh:

135 guruş

BE-CİHET-i

masârıf-ı dûlâb der âsitâne-i hazret-i İmam Ali raziyallahuteâlâanh:

75 guruş fî sene

BE-CİHET-i

bahâ-i şem'-i Berat ve seccâde berây-ı minber-i câmi'-i şerîf-i hazret-i İmam Ali:

$13^{1 / 2}$ guruş

BE-CİHET-i

bahâ-i şem'-i asel-i Berat berây-ı câmi'-i hazret-i İmam Hüseyin:

$7^{1 / 2}$ guruş

BE-CİHET-i

bahâ-i hasır berây-ı câmi'-i şerîf ve levâzım-ı âsitâne-i hazret-i İmam Hüseyin:

$72 \frac{1}{2}$ guruş

BE-CIHET-i

ücret-i pâsbânân-ı anbâr-ı gılâl der kasaba-i hazret-i İmam Hüseyin:

12 guruş

BE-CIHET-i

bahâ-i rûgan-ı şîr berây-ı tekke-i Bektâşiyân der Bağdad ve Hille: 28 guruş

BE-CİHET-i

bahâ-i şîr rûgan berây-ı âsitâne-i hazret-i İmam Hüseyin raziyallahuanh: 48 1/2 guruş

BE-CİHET-i

bahâ-i kandil ve pembe ve tel berây-ı câmi'-i hazret-i İmam Hüseyin: $7^{1 / 2}$ guruş 
BE-CIHET-i

ıydiye-i müezzinân-ı câmi'-i şerîf-i hazret-i İmam Hüseyin ber-mûcib-i mu’tâd-ı kadîm:

17 guruş

BE-CIHET-i

ıydiye-i hatib efendi ber-mûcib-i mu’tâd-ı kadîm:

10 guruş fî sene

BE-cïHeT-i

kirâye-i anbâr-ı gılâl der kasaba-i hazret-i İmam Hüseyin

7 guruş

BE-CIHET-i

bahâ-i seccâde berây-ı minber-i câmi'-i şerîf-i hazret-i İmâm Hüseyin raziyallahuteâlâanh:

8 guruş

BE-CİHET-i

bahâ-i kanâdil ve pembe ve tel berây-ı câmi'-i şerîf-i hazret-i İmam Ali raziyallahuteâlâ:

9 guruş

BE-CIHET-i

bahâ-i hıla' berây-ı mültezimân-ı kurâ-ı 'Azâr ber-mûcib:

200 guruş

BE-CíHET-i

harc-ı haffâr-ı nehr-i Hüseyniye ve hıla'-ı mu’temedân ber-mûcib:

25 o guruş

BE-CİHET-i

bahâ-i kalay berây-ı kazgan-ı imâret-i âmire, sarf şüde:

$4 \frac{1 / 2}{\text { guruş }}$

BE-CİHET-i

masârıf-ı vekîl-i mütevelli-yi Vakıf ber-mûcib-i mu’tâd-ı kadîm:

1959 guruş fî sene 


\section{BE-CİHET-i}

harc-ı imzâ-i mevlânâ müfettiş efendi ve kîsedâriye ve kalemiye bermûcib-i mu’tâd-ı kadîm:

100 guruş

BE-CİHET-i

harc-ı defter-i muhâsebe-i Vakıf ber-mûcib-i mu’tâd-ı kadîm:

200 guruş fî̀ sene

\section{'ANİ'L-MEREMMÂT-1}

mezkûrîn

1535 esedî guruş

\section{BE-CİHET-i}

harc-ı tamir kerden-i anbâr-ı gilâl, sarf şüde fî̀t-târîhi'l-mezbûr: 35 guruş

\section{BE-CİHET-i}

harc-ı tamir kerden-i hamam der kasaba-i hazret-i İmam Ali raziyallahu: 6oo guruş

\section{BE-CIHET-i}

harc-ı tamir kerden-i târem-i hazret-i İmam Ali raziyallahu: 300 guruş

\section{BE-CİHET-i}

harc-ı tamir kerden-i hân-ı cedîd fî̀t-târîhi'l-mezbûre: 6 oo guruş

$$
\text { [III] }
$$

Defter oldur ki bin yüz otuz üç senesi Eylülü ibtidâsından intihâsına varınca Meşhedeyn-i Şerîfeyn evkafının nakden ve gılâlen îrâd ü masârifi beyân olunur.

Fî'L-ASL

'ANI'L-ÎRÂD

mukâta’ât-ı hazret-i İmam Ali ve minhu hâsıl fî sene-i mezkûre: guruş $5375^{-12} 5^{1 / 2}$ tenzil $=4123^{1 / 2}$ 
resm-i kubûrât u nüzûrât der âsitâne-i İmam-ı müşârünileyh: guruş $35^{\circ}$

resm-i nüzûrât der âsitâne-i hazret-i İmam Hüseyin: guruş 220

kubûrât der âsitâne-i hazret-i İmam Hüseyin: guruş 125

icâre-i hân der kasaba-i hazret-i İmam Hüseyin: guruş 2950-100o tenzil $=1950$

icâre-i nısf-ı boya-hâne-i hazret-i İmam Hüseyin: guruş 525

icâre-i ma’sara-hâne-i hazret-i İmam Hüseyin: guruş $105^{\circ}$

icâre-i kasap-hâne der kasaba-i hazret-i İmam Hüseyin: guruş 1000

icâre-i tesbîh-sâzân der kasaba-i hazret-i İmam Hüseyin: guruş 1460-100o tenzil $=460$

icâre-i ?-1 kefen der kasaba-i hazret-i İmam Hüseyin: guruş 250-200 tenzil: 50

icâre-i pazar-ı taşlık der kasaba-i hazret-i İmam Hüseyin: guruş 85

icâre-i resm-i arûsâne-i kasaba-i mezkûre:

guruş 90

me’kele-i mütevelli-yi esnâf-ı kasaba-i mezkûre:

guruş 400

icâre-i subaşllık-ı kasaba-i mezkûre:

guruş 100 
deştbân-ı merta'-ı camış-ı kasaba-i mezkûre:

guruş 112

akçe-i meşîhat-i kurâ-i Vakf-ı şerîf el-vâkı der Hille:

guruş 6o

icâre-i dekâkîn vü hânehâ fî sene-i mezkûre:

guruş $2201 / 2$

akçe-i mâhiyâne ve ıydiye-i kurâ-ı Vakf-ı Şerîf el-vâkı der Hille:

guruş 90

icâre-i dekâkîn ü hânehâ der kasaba-i Hille:

guruş 11

icâre-i hân ü dekâkîn maa âsiyâb:

guruş $37^{1 / 2}$

icâre-i hamam ve nahl-i hurma ve mezraa-i Mendelcin:

guruş 40

mahsûl-i haffâr bedel-i hums der civâr-ı hazret-i İmam Hüseyin:

guruş 655

icâre-i semek der civâr-ı kasaba-i hazret-i İmam Hüseyin:

guruş 100

akçe-i bedel-i hafr-ı kurâ-ı Vakf-ı Şerîf el-vâkı der Hille:

guruş $25^{\circ}$

mahsûl-i nehr-i Mehâvil-eyn fî sene-i kâmile:

guruş $199^{1 / 2}$

mahsûl-i icâre-i ? ? ma’a nahl nehr-i Ümrân der Mehrûd:

guruş $267^{1 / 2}$

beytü'l-mâl-i A'câm:

guruş 25 
müjdegâne-i Kul fî sene-i kâmile:

guruş 10

mahsûl-i ser-dağar-ı maktû’ât-ı enhâr-ı Hüseyniye:

guruş 1153

mahsûl-i ser-dağar-ı maktû’ât-ı kurâ-ı Vakf-ı Şerîf el-vâkı der Hille:

guruş 265

mahsûl-i muhammen-i mezrû̉ât-ı bâğât der kasaba-i hazret-i İmam Hüseyin:

guruş 200

mahsûl-i hurmâ der kasaba-i Şefâte:

guruş 40

mahsûl-i ruusü’l-riyâcîl der kurâ ve mezâri'-i Hüseyniye:

guruş 225

mahsûl-i hurma-i Vakf-ı Şerîf der kasaba-i Hille:

guruş 1540

icâre-i dekâkîn-i cedîd ve kahve-hâne:

guruş $33^{1 / 2}$

YEKÛN

16063 guruş

\section{îrâd-ı gılâl bâ vezn-i Hallâvî}

+ enhâr-ı Hüseyniye 955 hınta +20o şaîr

+ kurâ-ı Vakf-ı Şerîf der Hille 215 hınta + 155 şaîr

$=1170$ hinta +355 şaîr

- ashâb-ı cerâye -96o hınta -45 şaîr =

= bâkî 210 hinta be-hesâb-ı hünkârî 105 fî esedî 4 ำ4 + 310 şaîr be-hesâb-ı hünkârî 154 1/2 fî esedî 2 3\%4

esedî guruş:

+ hinta $446^{1 / 4}+$ şaîr, $423^{1 / 2}$

$=8693 / 4$ 
MASÂRIF-1 MUKANNENE-i VAKF-1 ŞERÎF ve ZUHÛRÂT

BE-CİHET-i

ulûfe-i duâ-gûyân ve mütekaaidîn ve huddâm-ı âsitâne-i münevveri hazret-i İmam Ali ve hazret-i İmam Hüseyin ve hazret-i İmam Abbas rızvanallahuteâlâaleyhim ecma’în:

yevm 36o2, fî esedî 2

be-hesâb-1 guruş: 7204

BE-CİHET-i

imâret-i âsitâne-i hazret-i İmam Ali raziyallahuteâlâanh:

199 guruş

BE-CİHET-i

imâret-i âsitâne-i hazret-i İmam Hüseyin:

333 guruş

BE-CIHET-i

bahâ-i hıla'-i mültezimân ve şüyûh-ı esnâf ber-mûcib-i mu’tâd-ı kadîm:

140 guruş

BE-CIHET-i

bahâ-i şem'-i asel berây-ı âsitâne-i hazret-i İmam Ali:

135 guruş

BE-CİHET-i

masârıf-ı dûlâb der âsitâne-i hazret-i İmam Ali r.a.

75 guruş

BE-CIHET-i

şem'-i asel berây-ı âsitâne-i hazret-i İmam Hüseyin r.a.

135 guruş

BE-CİHET-i

şem'-i Berat ve bahâ-i seccâde-i minber-i câmi'-i şerîf-i hazret-i İmam Ali r.a.

$13^{1 / 2}$ guruş 
BE-CIHET-i

şem'-i Berat-ı câmi'-i şerîf-i hazret-i İmam Hüseyin:

$7^{1 / 2}$ guruş

BE-CIHET-i

bahâ-i hasır berây-ı câmi'-i şerîf ve levâzım-ı hazret-i İmam Hüseyin ve İmam Abbas:

$72 \frac{1}{2}$ guruş

BE-CİHET-i

ücret-i pâsbânân-ı gilâl-ı anbâr der kasaba-i hazret-i İmam Hüseyin r.a.

12 guruş

BE-CIHHET-i

bahâ-i şîrûgan-ı tekke-i Bektâşiyân der Bağdad ve Hille:

28 guruş

BE-CIHET-i

bahâ-i şîrûgan berây-ı âsitâne-i hazret-i İmam Hüseyin r.a.

48 1/2 guruş

BE-CİHET-i

bahâ-i kanâdîl ve penbe ve tel berây-ı câmi'-i şerîf-i hazret-i İmam Hüseyin:

$7^{1 / 2}$ guruş

BE-CİHET-i

ıydiye-i müezzinân-ı câmi'-i şerîf-i hazret-i İmam Hüseyin:

17 guruş

BE-CIHET-i

lydiye-i hatîb efendi ber-mûcib-i mu’tâd:

10 guruş

BE-CIHET-i

kirâye-i gılâl:

7 guruş

BE-CIHET-i

bahâ-i seccâde berây-ı minber-i câmi’-i şerîf-i hazret-i İmam Hüseyin:

8 guruş 
BE-CIHET-i

ta'mîr-i anbâr-ı gllâl:

35 guruş

BE-CİHET-i

bahâ-i kanâdîl ve penbe ve tel berây-ı câmi’-i şerîf-i hazret-i İmam Ali r.a.

9 guruş

BE-CIHET-i

bahâ-i hıla'-ı mültezimân-ı hurma-i 'Azâr:

200 guruş

BE-CİHET-i

haffâr-ı nehr-i Hüseyniye ve hıla'-ı mu’temedân;

250 guruş

BE-CİHET-i

masârıf-ı vekîl-i mütevelli fî sene-i kâmile:

1959 guruş

BE-CIHET-i

bahâ-i kalay berây-ı kazgan-ı imâret:

$4^{1 / 2}$ guruş

BE-CIHET-i

bedel-i surre:

1000 guruş

BE-CİHET-i

zevâid-i Vakf-ı Şerîf:

3000 guruş

BE-CIHET-i

harc-ı muhâsebe:

300 guruş

BE-CİHET-i

termîm-i hamam der kasaba-i hazret-i İmam Ali r.a.

6 oo guruş 


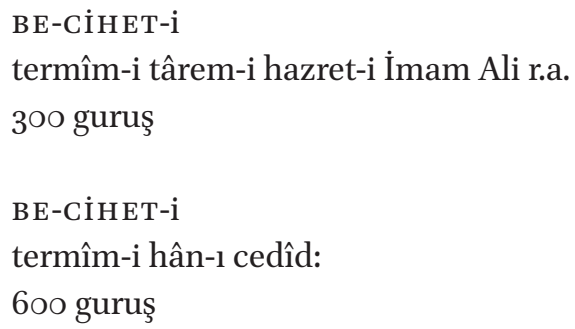

Maruz-ı kulları budur ki:

işbu defter nâtık olduğu üzere, Meşhedeyn-i Şerîfeyn Evkafi’nın inkıtâ’-ı züvvâr- Acem sebebi ile bazı mukaataaları tenzil ile iltizâma verilip, asl-ı malı ve hâlen tenzîli aynıyla tahrir olunup, sene-i mezkûrede gılâl bahâsıyla min-haysi'l-mecmû’ onaltıbin dokuzyüz otuz iki buçuk guruş bir rub’ îrâdı ve onaltıbin yediyüz on guruş masârıfı olmağın, masârıf-ı mezkûre îrâd-ı merkumdan fürû-nihâd olduktan sonra sahhü'l-baakî ikiyüz yirmi iki buçuk guruş bir rub’ der-kîse olmak üzere meblağ-ı mezkûr dahi irsâl olunmuştur. Vusûlunda ahz ü işbu defter mahalline kayıt ve bendelerine senet olmak için sûret-i vusûl ihsân buyurulmak mercûdur. Ol bâbda emr ü fermân der-i ma'delet-nişânındır. Tahrîren fî 2 R[ebîulâhir] sene 1135 .

bende:

Hasan, muhâfız-ı Bağdad hâlen

[mühür]

EL-BAAK $\hat{I}$

$4445^{3 / 4}$ esedî guruş

MİN-ZÂLİK-EL-BAAKî

4222 3/4 esedî guruş

BE-CİHET-i

edâ-yı akçe-i bedel-i surre, teslîm be Hazîne-i Haremeyn-i Şerîfeyn, an yed-i Emin Mehmed Ağa kethüdâ-yi bâb-ı hazret-i vezîr-i müşârunileyh, Zilkade sene 1133:

1000 guruş fî̀ sene. 
BE-CİHET-i

edâ-yı akçe-i zevâid-i Vakıf, teslîm be Hazîne-i Haremeyn-i Şerîfeyn, an yed-i Emin Mehmed Ağa el-mezbûr, Zilkade sene-i minhu: 3 ooo guruş fî sene.

\section{BE-CİHET-i}

edâ-yı akçe-i der-kîse-i Vakıf, makaam-ı kaabız, an Muhâsebe-i Evvel, Zilkade sene 1133, teslîm be Hazîne-i m an yed-i m:

$222 \frac{1}{2}$ guruş

SAH HÜ'L-BAAKî-yi

der-kîse-i makaam-ı kaabız:

$2223 / 4$ esedî guruş

\section{Belge 21 (Münşeat-ı Nazmizâde Murtazâ, ff. 38b-39b) diplomatik mektup, münşeat mecmuası kopyası}

(Bağdad beylerbeyinden İran sadrazamına)

... refî̀-menzilet, Süreyyâ-rütbet, mu’temed-i Devlet-i İran-penâhî, bülend-mekân-ı Âsafî-nişân, hân-ı âlişân hazretlerinin gülzâr-ı vâlâ-rây-ı himmet-i kişver olan nâdî-yi refî-i mekârim-güster ü meclis-i sâmî-yi ahâliperverlerine ma’âdin-i sıdk u ma’nâ vü hadâyık-ı mihr ü vefâdan nâşi vü gubâr-ı reyb ü riyâdan mütehâşî olan cevâhir-i de’âvât-ı sadâkat-levâmi' vü zevâhir-i teslîmât-ı isâbet-tavâlî, ki revnak-bahşâ-yı encümen-i vedd ü ülfet ve ziynet-efzâ-yı kâşâne-i dûstî vü muhabbettir, ithâfiyla kümeyt-i kilki hümâ-peyker sahn-ı saadet-i yegânegîde bu resme cilveger olur ki: bu sâl-i ferhunde-fâlde Bağdâd-ı Dârüsselâm tarîkından hacc-ı Beytullahi'l-Harâm ü ziyâret-i Ravza-i Seyyidü'l-Enâm (aleyh efdalit-tahiyye ve's-selâm)'a niyet ve bu tarîk-ı hidâyet-refîka azîmet eden hüccâc-ı felâh-minhâcın zehâb ü iyâblarına temşiyet ü levâzım-ı hıfz u hırâsetleri hizmetine kıdvetü'l-emâsil ve'l-akrân [] Beyg emîrü'l-hacc tayin olunup, memâlik-i İran'dan bu sene-i mübârekede kasd-ı tavâf-ı melâik-matâf-ı Beyt-i Atıyk u niyet-i ziyâret-i Ravza-i Benî Şefiyk (aleyh el-tahiyye ve'l-tekrîm) eden hüccâc-ı zi'l-ibtihâca ruhsat verilip, keştzâr-ı âmâl-i Müslimîn sehâb-ı mekremetleri ile reyyân ü terîn buyurulmak bâbında mektûb-i sadâkat-âgîn rakam-zede-i kalem-i muhabbet-rakam kılınmıştır. İnşâ-allahu-teâlâ mutâlaa-i âlîleriyle şeref-yâb oldukta, mezbûr bendeleri üzerinden nazar-ı kimyâ-eserlerin bî-dırîğ buyurup zümre-i hâc dẩileri kemâl-i ümîd ü istimâlet ü tamâm-ı tesliyet ü tergıyb birle revâne buyurulmağa himemi kâmile vü hüsn-i teveccüh-i şâmmeleri der-kâr buyurulmak me’mûldür. Bu bâpta mebzûl buyurulan takayyüd-i girâmîleri müstelzim-i nîk-nâmî olduğu 
zamîr-i hûrşîd-tenvîrlerine pûşîde değildir. İnşâ-allahu-teâlâ, bu muhlisleri dahi himâyet ü riâyetlerinde her vechle teşmîr-i sâk-ı ihtimâm ü bezl-i takayyüd-i mâ-lâ-kelâm etmek emr-i mukarrer olduğundan gayrı, şâh-râh-ı hüccâc ü züvvâr güşâde vü esbâb-ı husûl-ı âmâl-i Müslimîn âmâde olmak muharrik-i silsilei muhabbet ü hullet olup, sebeb-i takviyet-i erkân-ı sulh-i râsihü'l-imâd ü bầis-i terfîh-i hâl-i âmme-i ibâd olduğu reyb ü riyâdan müberrâdır.

\section{Bibliography}

\section{Documents}

Presidential Ottoman Archives-Istanbul.

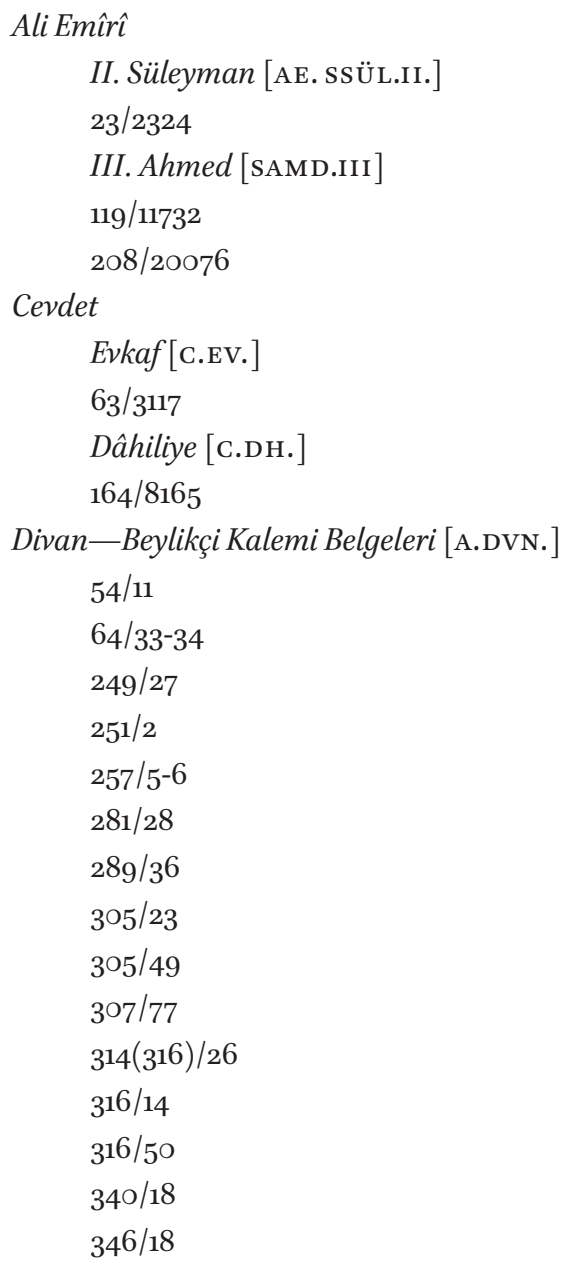




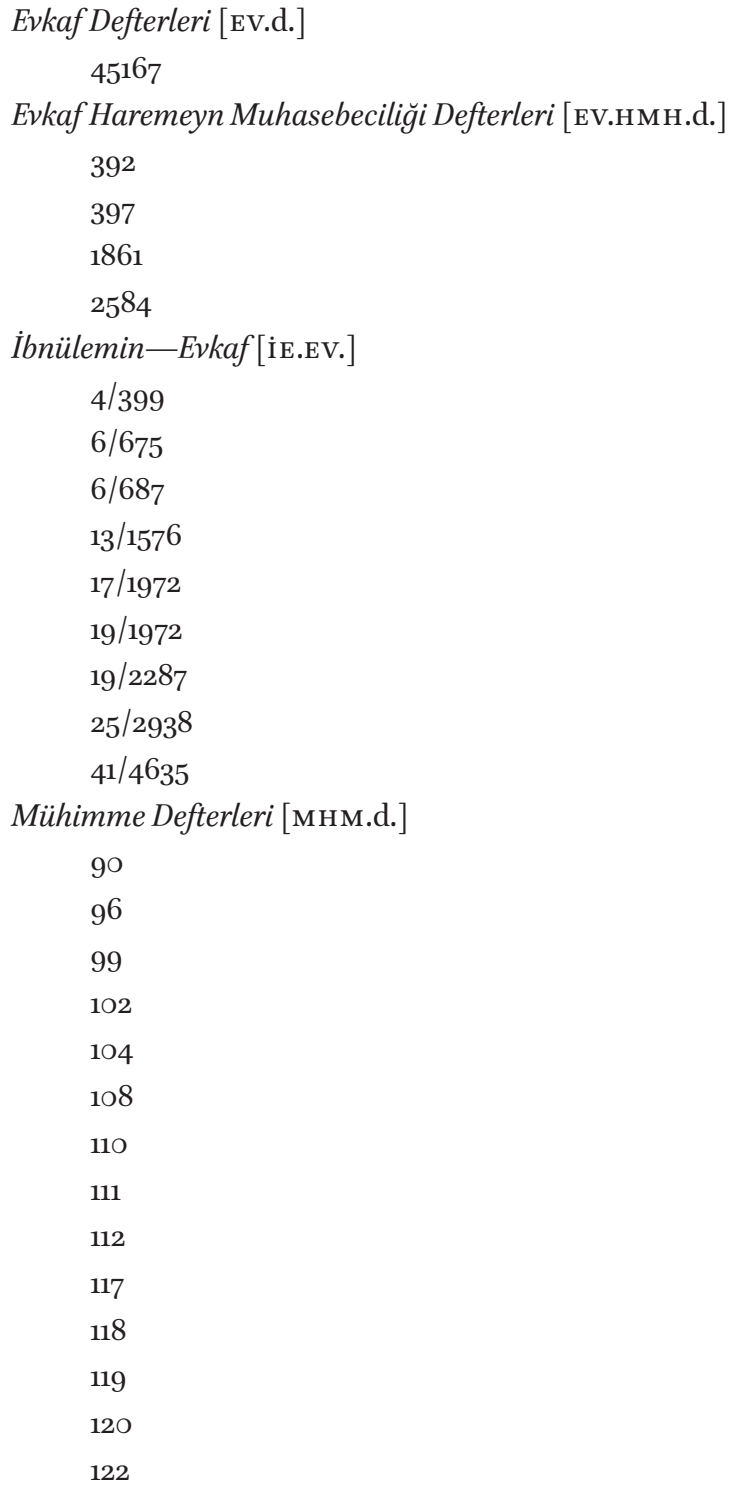

Nâme-i Hümâyun Defterleri [NMH.H.d.]

5

Sadâret Mektûbî Kalemi Belgeleri [A.M KT.]

$1 / 56$

Topkapı Sarayı Müzesi Arşivi, Evrak [TSMA.E.]

$302 / 3$

$303 / 61$

$822 / 12$ 


$$
\begin{aligned}
& 833 / 25 \\
& 1132 / 38 \\
& 1166 / 43 \\
& 1288 / 102 \\
& 1402 / 56 \\
& 1412 / 76
\end{aligned}
$$

Nazmizâde, Hüseyin Murtazâ Efendi Bağdâdî. Münşeât-ı Nazmizâde. Süleymâniye Yazma Eserler Kütüphânesi, Esad Efendi n. 3322.

Râmî Mehmed. Münşeat. Österreichische Nationalbibliothek H.o. 179.

\section{Published Sources}

[of Agulis, Zak'aria.] Journal Zak'aria of Agulis. 2003. Translated and edited by George A. Bournoutian. Costa Mesa, CA: Mazda Publishers.

Anonim Osmanlı Tarihi (1099-1116/ 1688-1704). 2000. Edited by Abdülkadir Özcan. Ankara: Türk Tarih Kurumu Basımevi.

Asnād u Mukātabāt-i Siyāsī-i İrān az sāl-i 1105 tā 1135 h-q. hs. 1363, hs. 1363. Edited by 'Abdulḥusayn Navāī. Tehran: Muassasa-i Mutālacāt u Tahqīqāt-i Farhangī.

Evliyâ Çelebi b. Derviş Mehemmed Zıllî. 2011. Evliyâ Çelebi Seyahatnamesi. 10 books in 2 vols. Edited by Seyit Ali Kahraman, Yücel Dağlı, Robert Dankoff, Zekeriya Kurşun, and İbrahim Sezgin. Istanbul: Yapı Kredi Yayınları.

Findıklılı Mehmed Ağa, Silâhdâr. 2018. Nusretname. Edited by Mehmet Topal. Ankara: Türkiye Bilimler Akademisi.

Fındıklılı Mehmed Ağa, Silahdar. 2002. Zeyl-i Fezleke. Edited by Nazire Karaçay Türkal as PhD Dissertation, "Silahdar Fındıklılı Mehmed Ağa: Zeyl-i Fezleke (1065-22 Ca.1106 / 1654-7 Şubat 1695)." Marmara Üniversitesi, Istanbul.

Khātūnābādī, 'Abdulhusayn. hs 1352. Vaqāyi'u's-Sinīn va'l-A'vām. Edited by Muḥammad Bāqir Bihbūdī. Tehran: Kitāb-furūshī-yi Islāmiya.

Majlisī, Muḥammad Bāqir. 1261 [1845]. Tuhfatu'z-Zā’ir. Tabriz (from the copy at the Staatsbibliothek zu Berlin, 4" Zu 43964).

Nasīrī, Muḥammad Ibrāhīm. hs. 1373. Dastūr-i Shahriyārān. Edited by Muhammad Nādir Nasīn̄i Muqaddam. Tehran: Bunyād-i Mauqūfāt-i Doktor Maḥmūd Afshār.

[Nazmizâde Hüseyin Murtazâ Efendi Bağdâdî.] 1995. Târih-i Sefer-i Basra. Edited by Vahid Çubuk in "Nusret-name'nin Kaynaklarından Tarih-i Seferü'l-Basra," Istanbul Üniversitesi Edebiyat Fakültesi Tarih Enstitüsü Dergisi 15: 321-380.

Sarı Mehmed Paşa, Defterdar. 1995. Zübde-i Vekayiât: Tahlil ve Metin (1066-1116 / 16561704) Edited by Abdülkadir Özcan. Ankara: Türk Tarih Kurumu Basımevi.

\section{Secondary Literature}

Akgündüz, Ahmet. 1988. İslam Hukukunda ve Osmanlı Tatbikatında Vakıf Müessesesi. Ankara: Türk Tarih Kurumu Basımevi. 
Ateş, Sabri. 2010. Bones of Contention: Corpse Traffic and Ottoman-Iranian Rivalry in Nineteenth-Century Iraq. Comparative Studies of South Asia, Africa and the Middle East 30/3: 512-532.

Burak, Guy. 2017. Between Istanbul and Gujarat: Descriptions of Mecca in the Sixteenth-Century Indian Ocean. Muqarnas 34: 287-320.

Can, Lâle. 2020. Spiritual Subjects: Central Asian Pilgrims and The Ottoman Hajj at the End of Empire. Stanford, CA: Stanford University Press.

Erginbaş, Vefa. 2017. Problematizing Ottoman Sunnism: Appropriation of Islamic History and Ahl al-Baytism in Ottoman Literary and Historical Writing in the Sixteenth Century. Journal of the Economic and Social History of the Orient 6o: 614-646.

Faroqhi, Suraiya. 199o. Herrscher über Mekka: die Geschichte der Pilgerfahrt. Munich: Artemis Verlag.

Güngörürler, Selim. 202O. Islamic Discourse in Ottoman-Safavid Peacetime Diplomacy after 1049/1639. In Historicizing Sunni Islam in the Ottoman Empire, c. 1450-c. 1750, edited by Tijana Krstić and Derin Terzioğlu. Leiden: Brill: 479-500.

Ja'farian, Rasool. hs. 1393. Kāvishhā-yi Tāza dar Bāb-i Rūzgār-i Șafavī. Qum: Adyan Publication, 2nd edition.

Jafarian, Rasool. hs 1389-1391. Șafaviya dar 'Arsa-i Dīn, Farhang u Siyāsat. Vols. 1-2. Pizhuhish-gāh-i Hauza vu Dānishgāh.

Krstić, Tijana. 2011. Contested Conversions to Islam: Narratives of Religions Change in the Early Modern Ottoman Empire. Stanford, CA: Stanford University Press.

Matthee, Rudi. 20o6. Between Arabs, Turks and Iranians: The Town of Basra, 160o-170o. Bulletin of School of Oriental and African Studies 69/1: 53-78.

Matthee, Rudi. 2012. Persia in Crisis: Safavid Decline and the Fall of Isfahan. London \& New York: I.B. Tauris.

Matthee, Rudi. 2003. The Safavid-Ottoman Frontier: Iraq-i Arab as seen by the Safavids. International Journal of Turkish Studies 9/1-2: 157-173.

Melville, Charles. 1996. Shah 'Abbas and the Pilgrimage to Mashhad. In Safavid Persia: The History of Politics of an Islamic Society, ed. Charles Melville. London: I.B. Tauris: 191-23o.

Pearson, Michael N. 1996. Pilgrimage to Mecca: The Indian Experience, 1500-1800. Princeton: Markus Wiener Publishers.

Ramazani, Rouhollah K. 1966. The Foreign Policy of Iran 1500-1941. Charlottesville: University Press of Virginia.

al-Rubaye, Wameedh Sarhan. 2020. Bağdat Vakıfları (1534-183o). Phd Dissertation, Gazi Üniversitesi, Ankara.

Shafir, Nir. 2020. In an Ottoman Holy Land: The Hajj and the Road from Damascus, 1500-180o. History of Religions 6o/1: 1-36. 
Șifat-Gul, Manșūr. hs. 1381. Sākhtār-i Nihād u Andīsha-i Dīnì dar İrān-i 'asr-i Șafavī. Tehran: Khidamāt-i Farhangī-yi Rasā.

Terzioğlu, Derin. 2012-2013. How to Conceptualize Ottoman Sunnitization: A Historiographical Discussion. Turcica 44: 301-335.

Türkiye Diyânet Vakfi İslam Ansiklopedisi. 1991. vol. 4: 49-50. "Atebât" by Avni İlhan.

1994. vol. 9: 541-542. "Duâgû" by Mehmet İpşirli.

2002. vol. 25: 271-272. "Kerbelâ" by Mustafa Öz.

2004. vol. 29: 365-366. "Meşhed-i Ali" by Abdüsselam Uluçam.

2006. vol. 32: 486-487. "Necef" by Mustafa Öz.

Winter, Stefan. 2010. The Shiites of Lebanon under Ottoman Rule. Cambridge: Cambridge University Press.

Yıldırım, Rıza. 2019. The Rise of the 'Religion and State' Order: Re-confessionalization of State and Society in the Early Modern Ottoman Empire. In Ottoman Sunnism, edited by Vefa Erginbaş. Edinburgh: Edinburgh University Press: 12-46. 


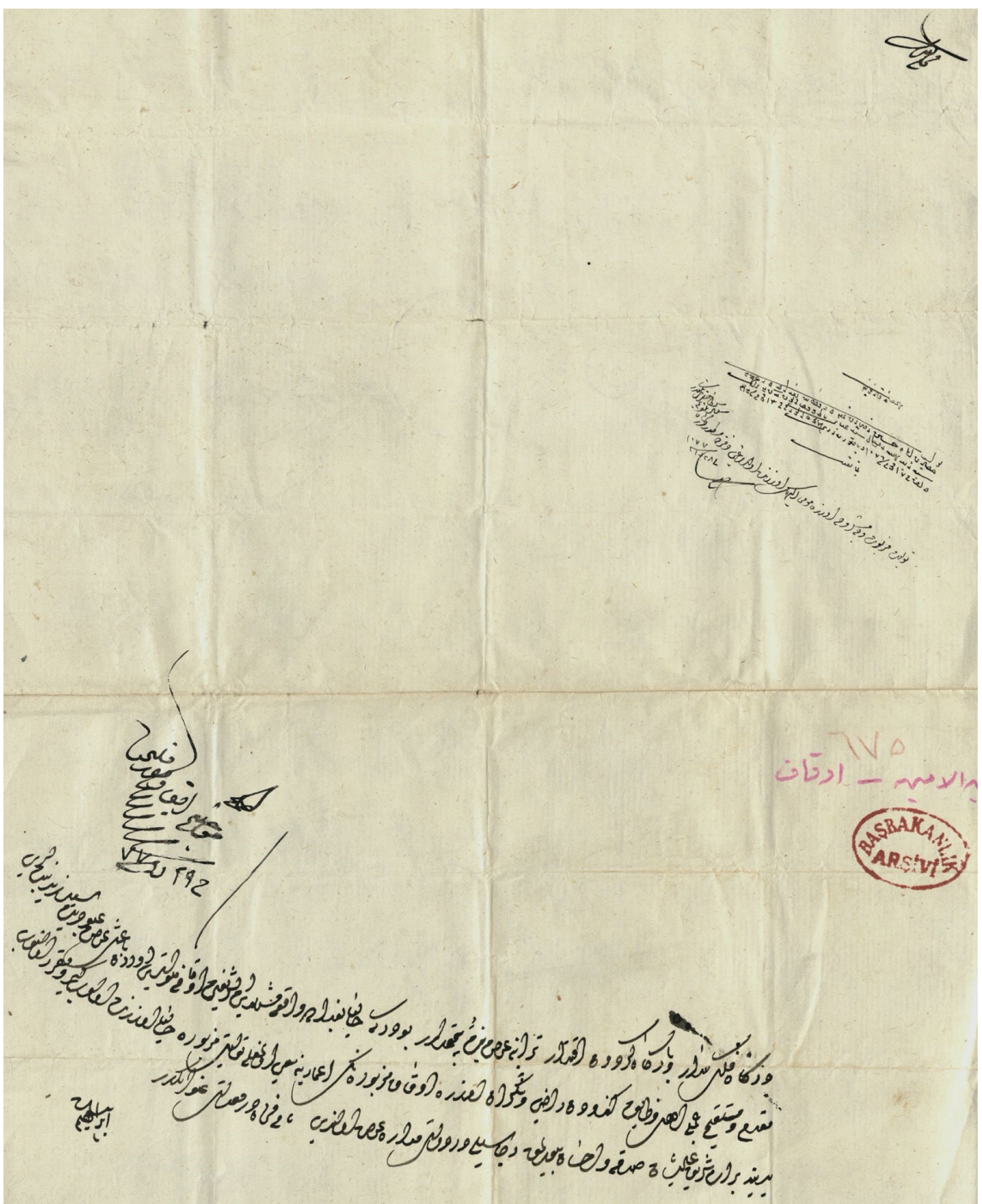

Doc. 1 İbnülemin-Evkaf, 6 / 675 


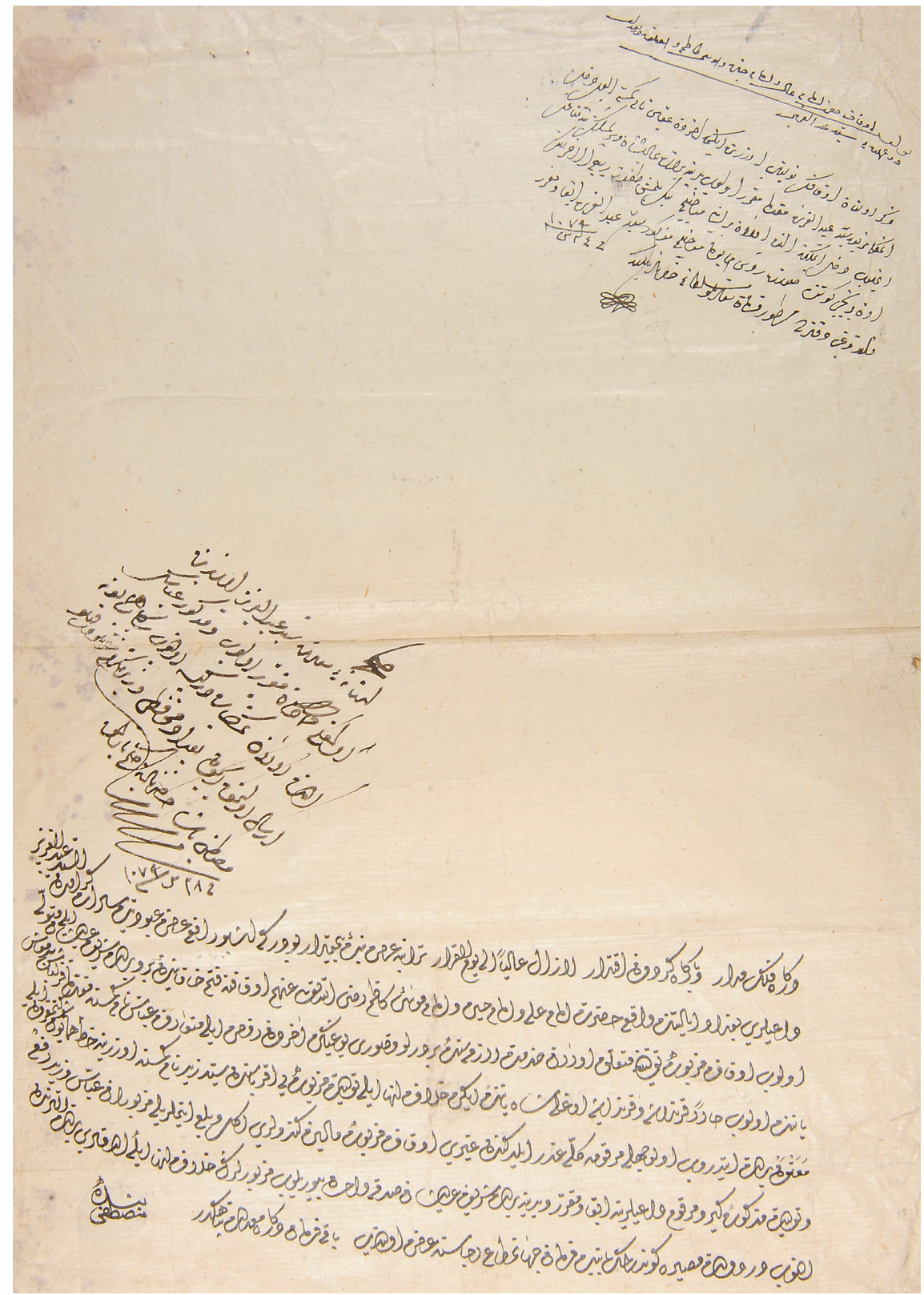

Doc. 2 Bab-ıAsafi-Beylikçi(Divan) Kalemi Belgeleri, 54 / 11 


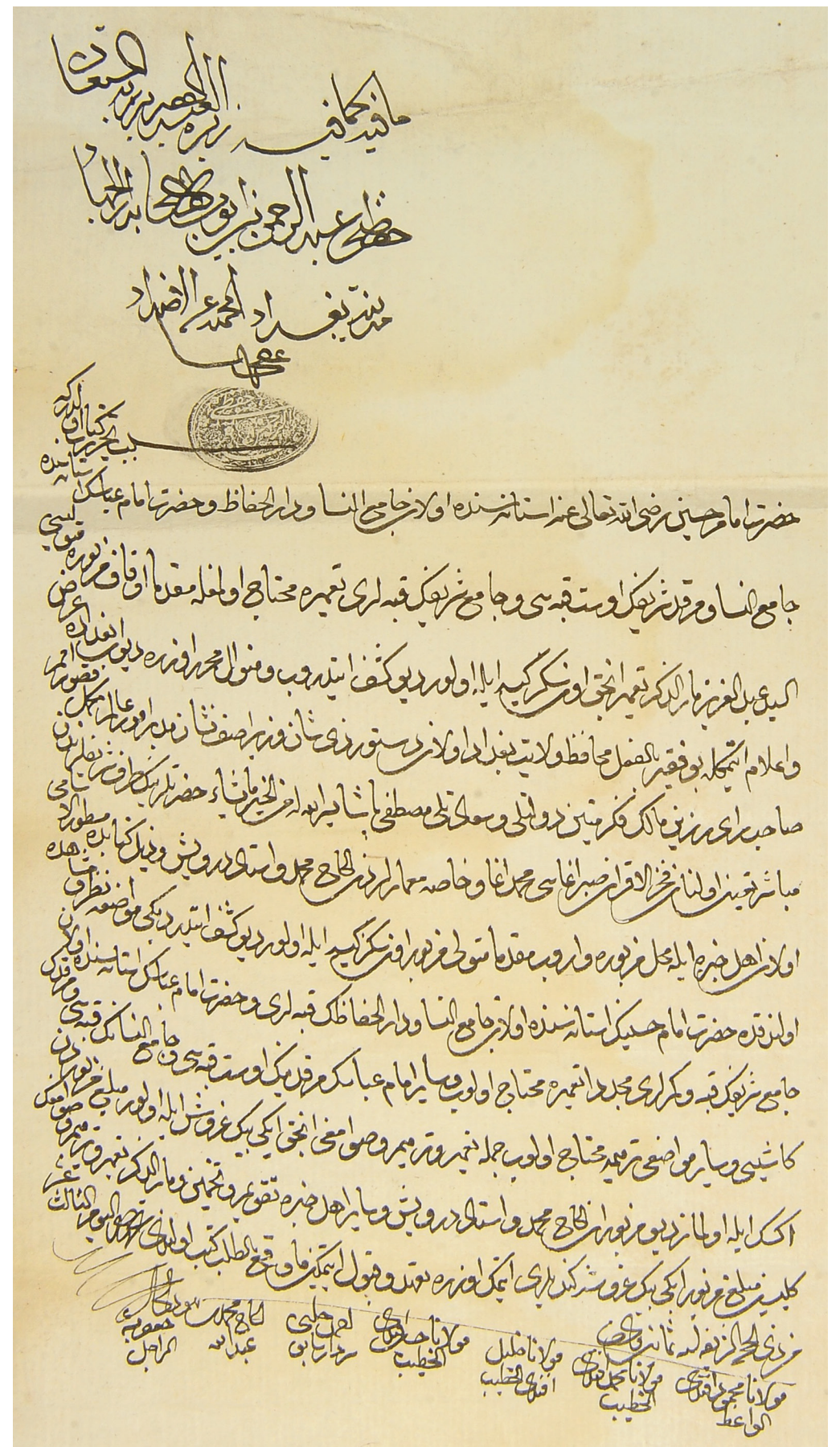

Doc. 3 Ibnülemin-Evkaf, 13 / 1576 


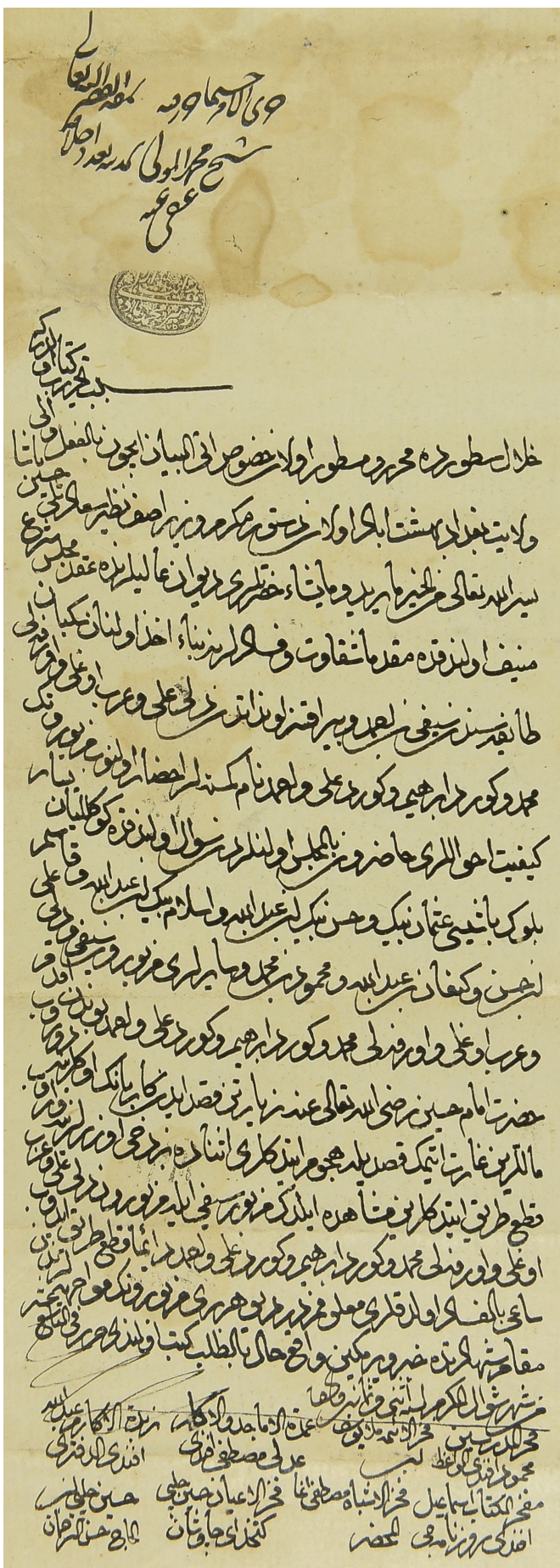

DOC. 4

Bab-ıAsafi-Beylikçi

(Divan) Kalemi Belgeleri, $64 / 33$ 


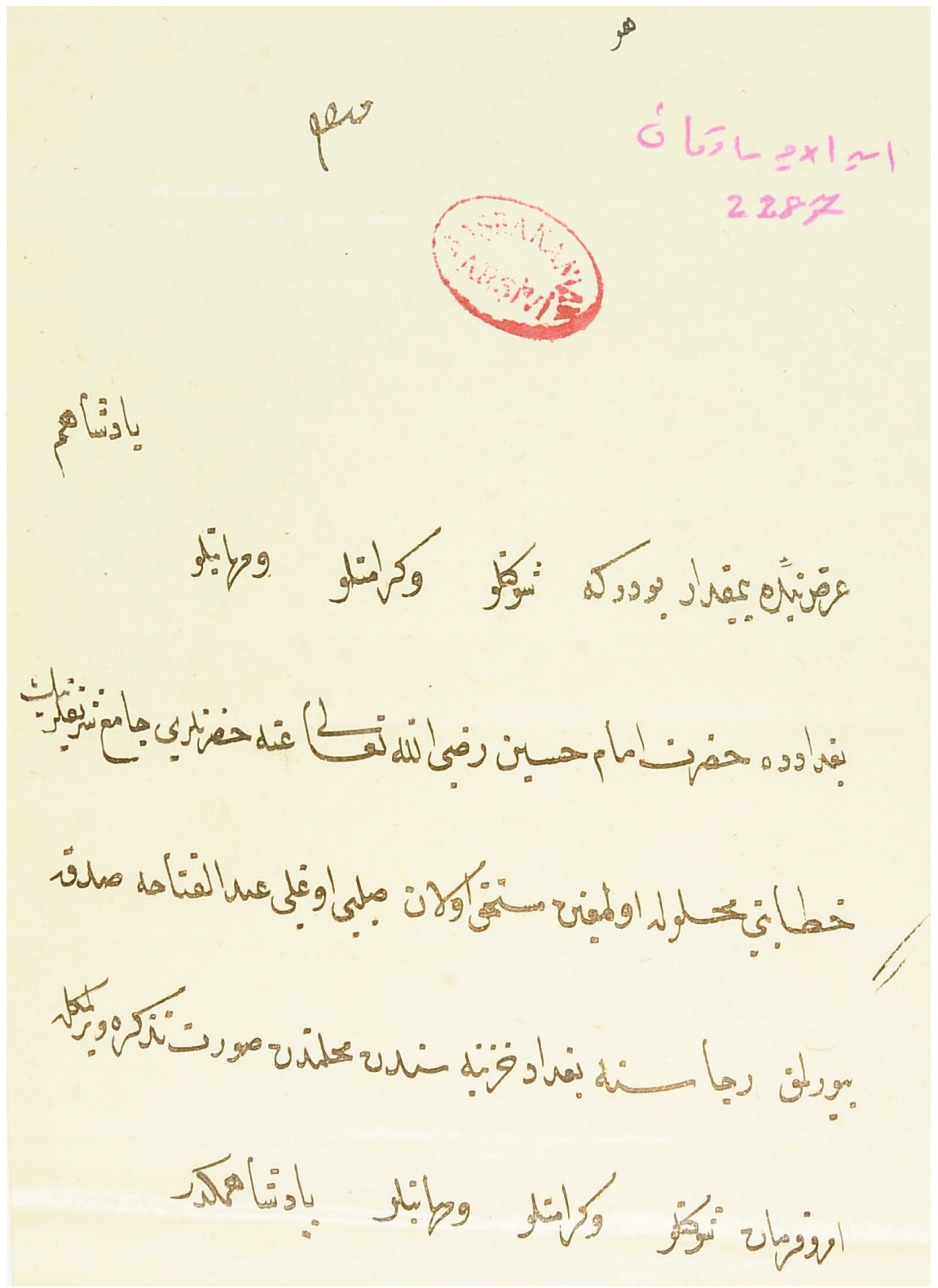

Doc. 5 İbnülemin-Evkaf, 19 / 2287 


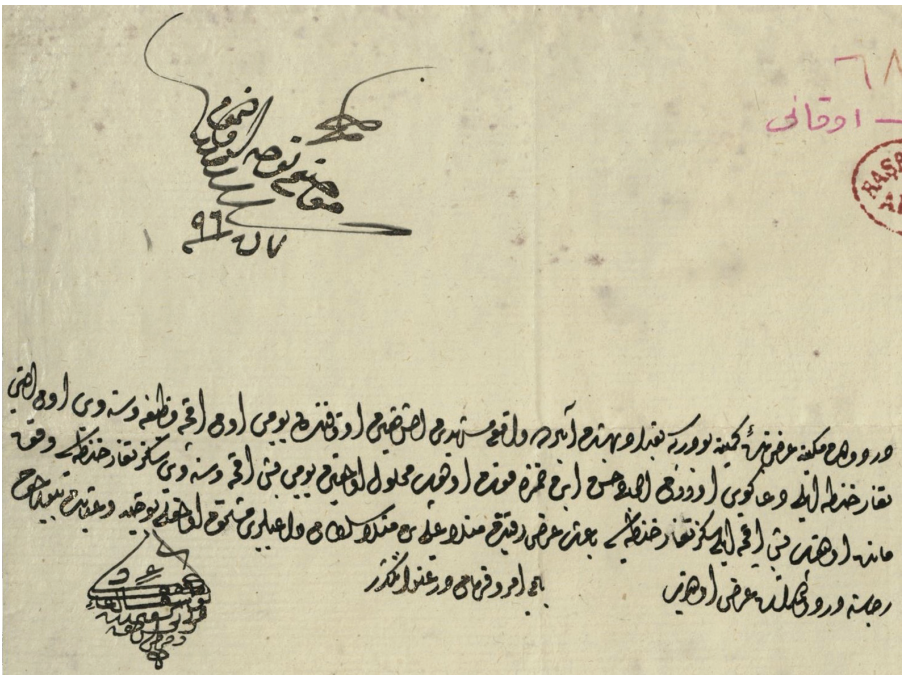

Doc. $6 \quad$ İbnülemin—Evkaf, 6 / 687

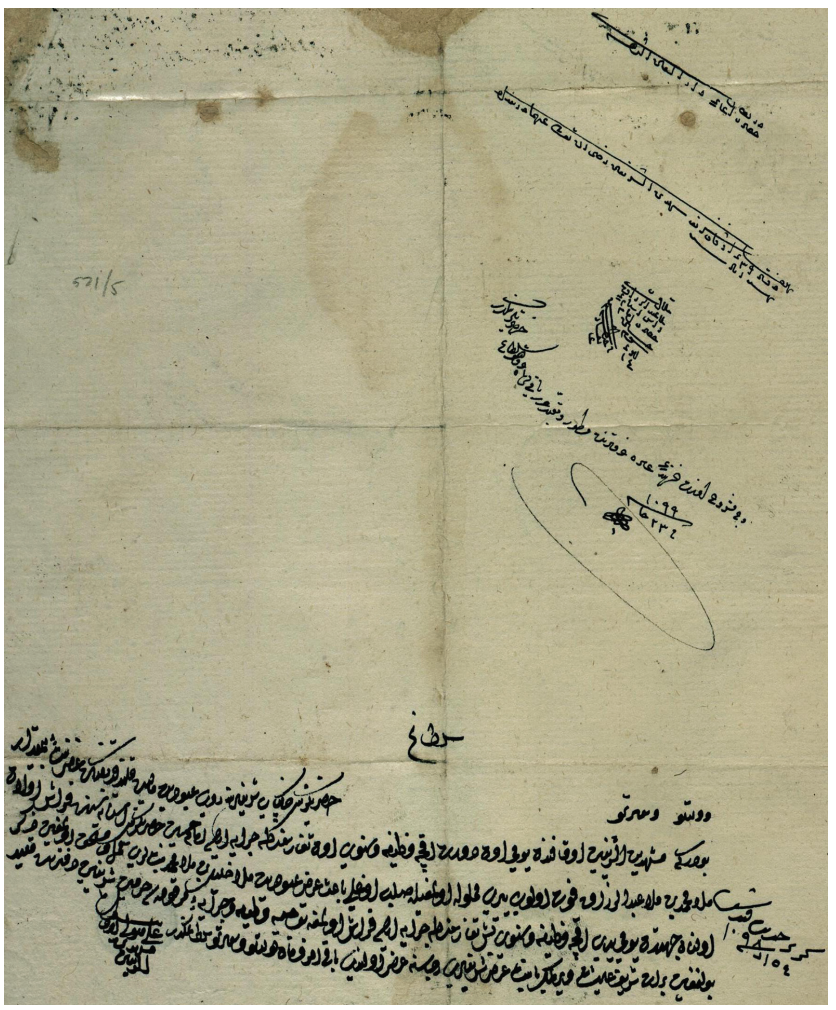

Doc. 7 Topkapı-Evrak, 1288 / 102 


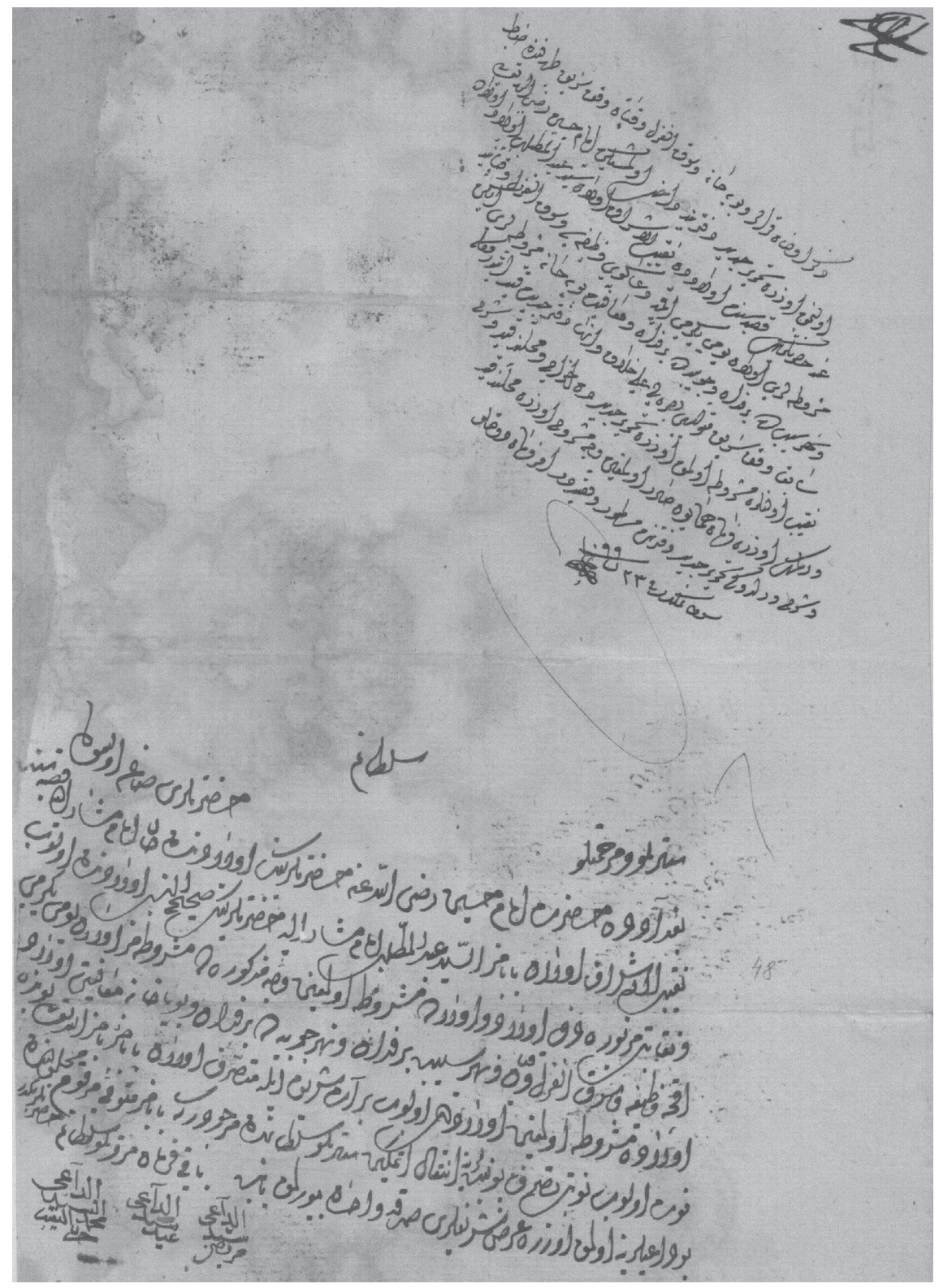

Doc. 8 Topkapı-Evrak, 1166 / 43 


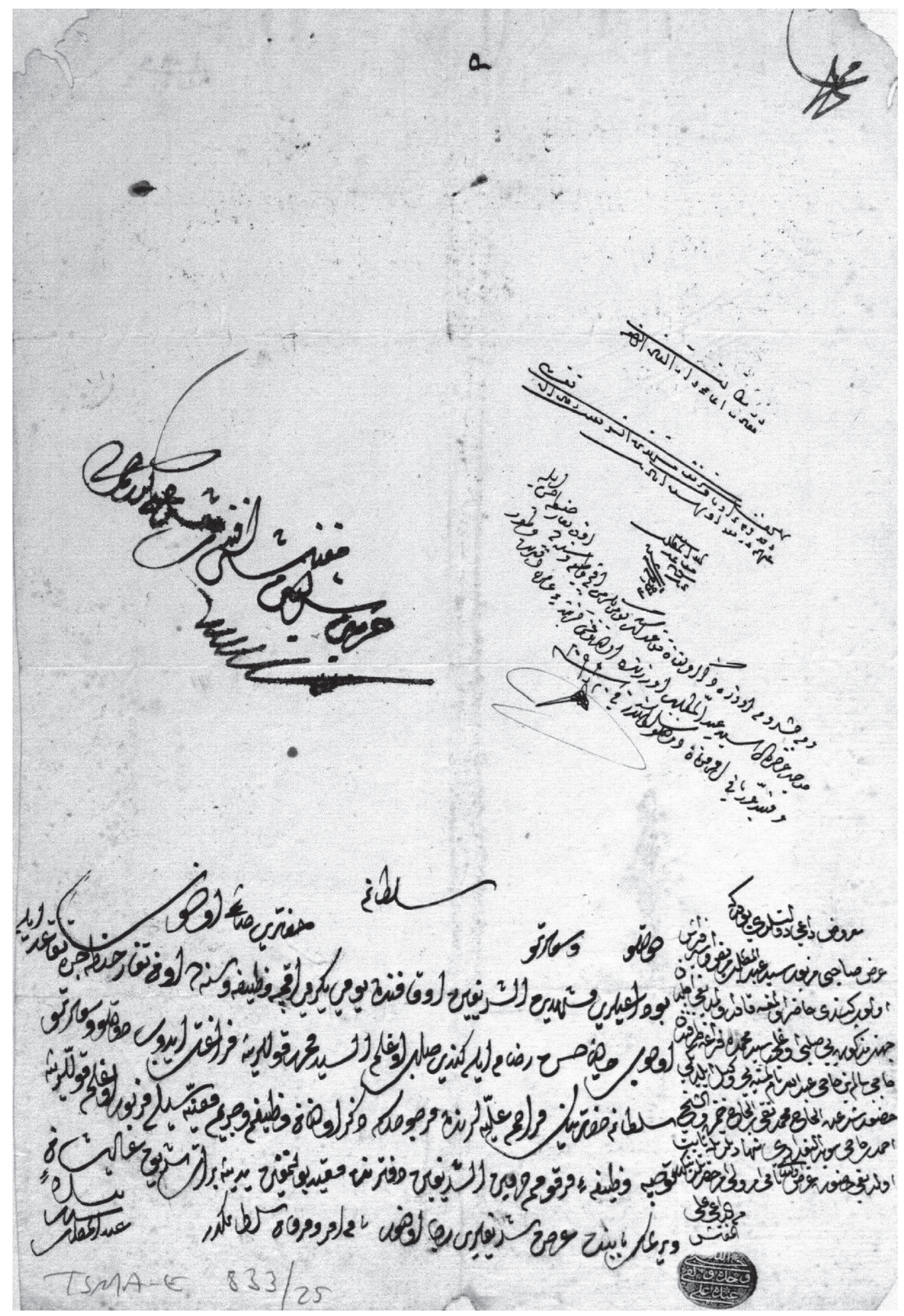

Doc. 9 Topkapı-Evrak, 833 / 25 


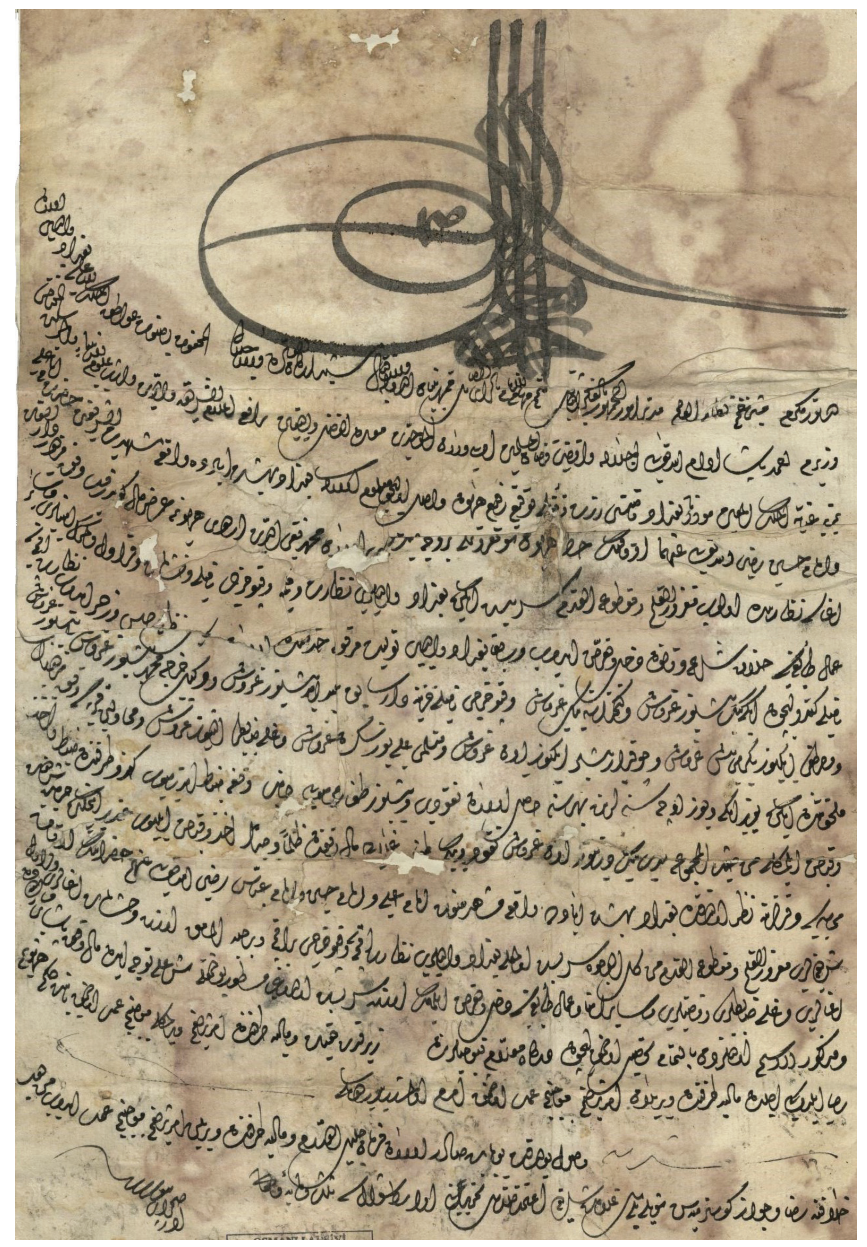

Doc. 10 İbnülemin-Evkaf, 25 / 2938

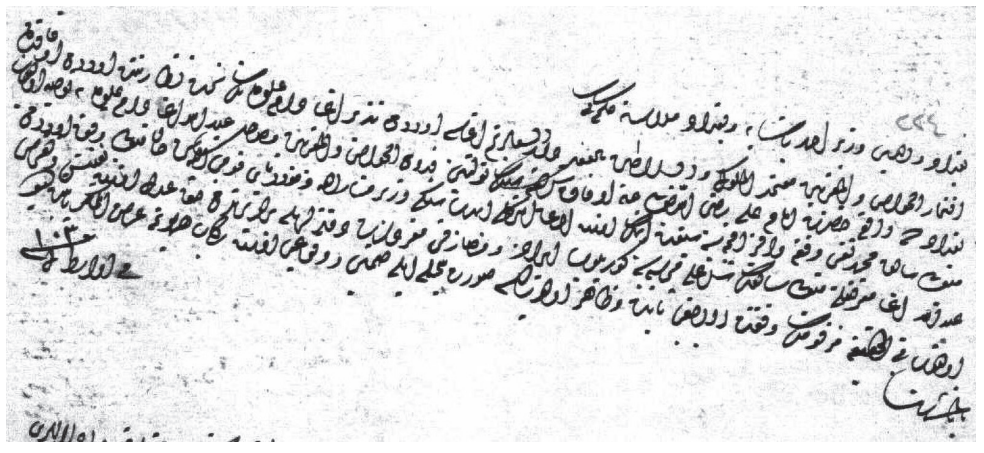

DOC. 11 Mühimme Defteri 104, entry 224 


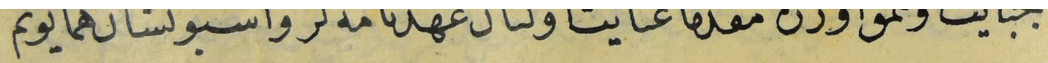

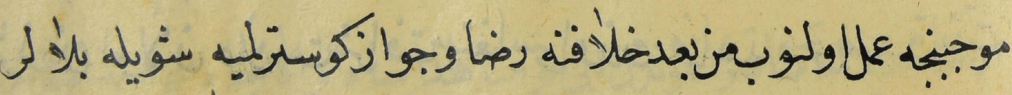

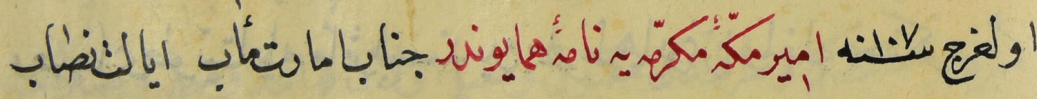

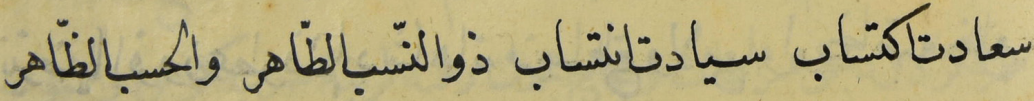

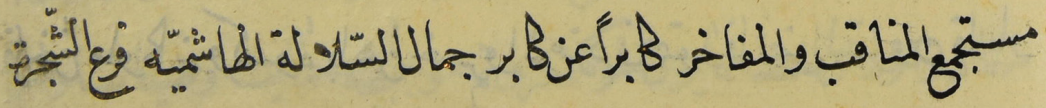

Doc. 12A Name-i Hümayun Defteri 5 , entry 86

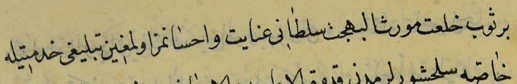

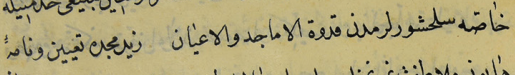

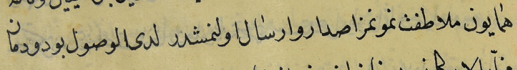

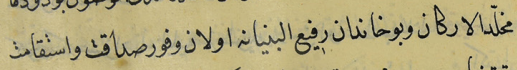

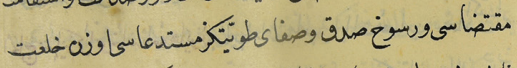

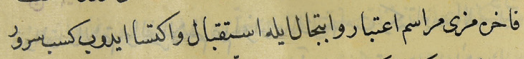

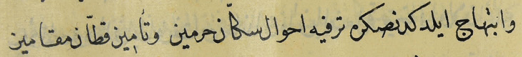

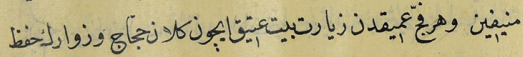

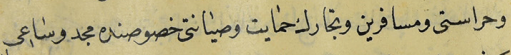

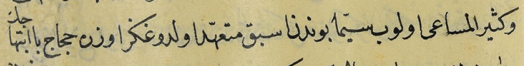

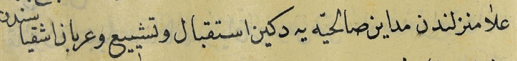

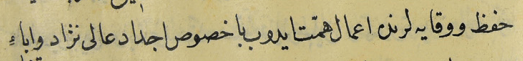

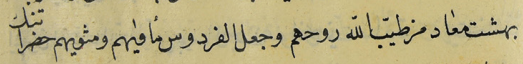

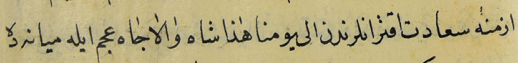

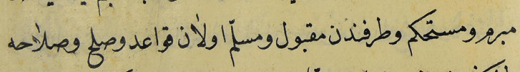

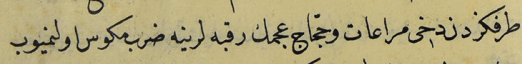

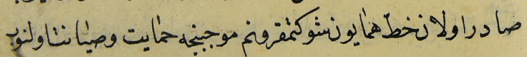

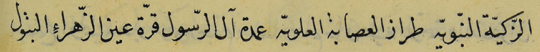

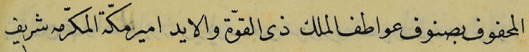

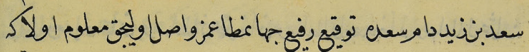

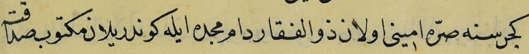

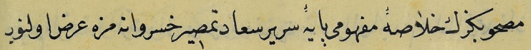

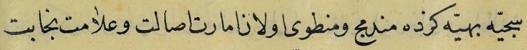

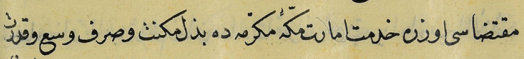

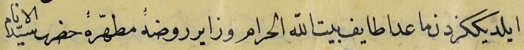

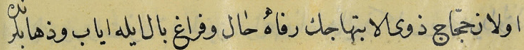

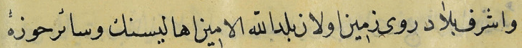

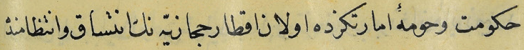

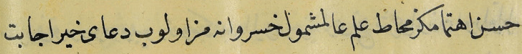

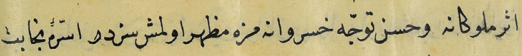

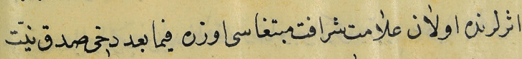

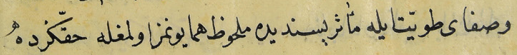

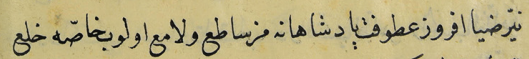

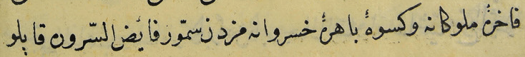

DOC. $12 \mathrm{~B}$ 


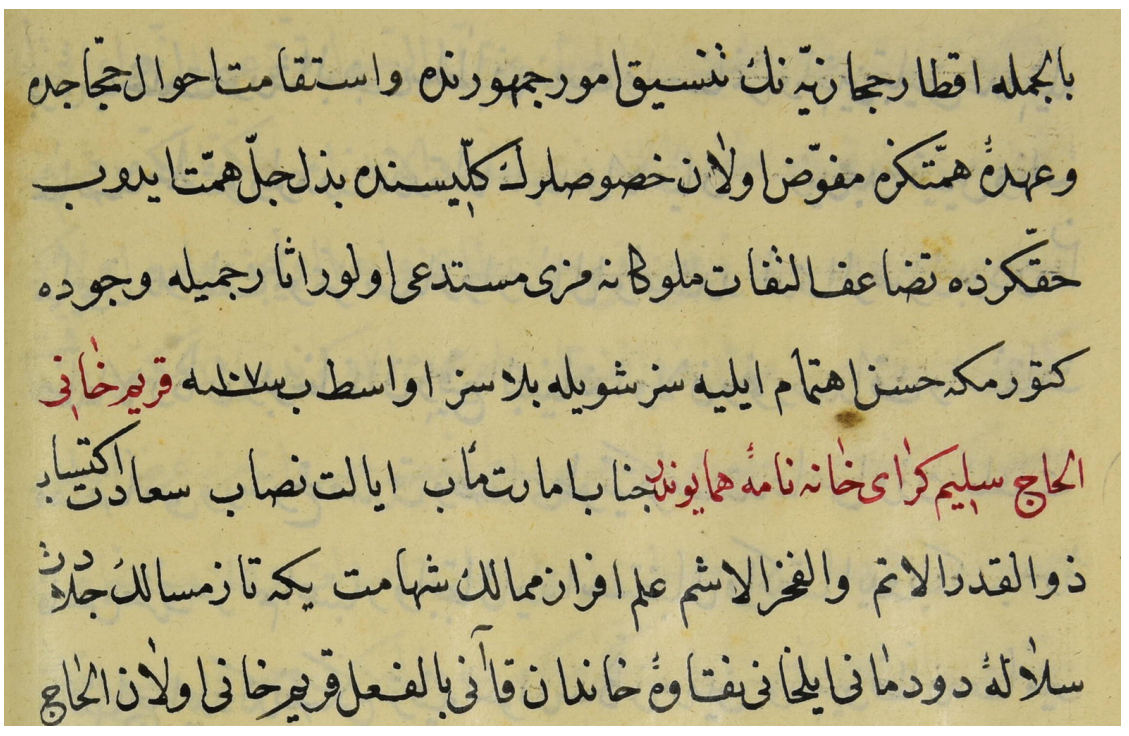

DoC. $12 \mathrm{C}$

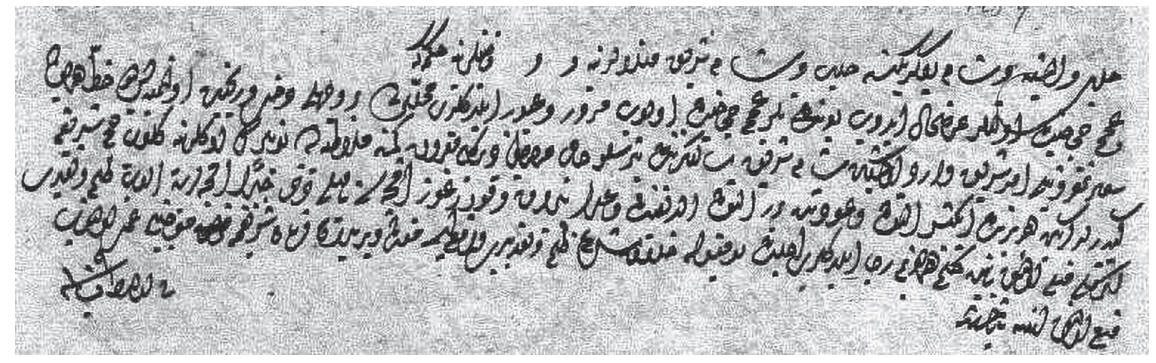

Doc. 13 Mühimme Defteri 110, entry 1259 


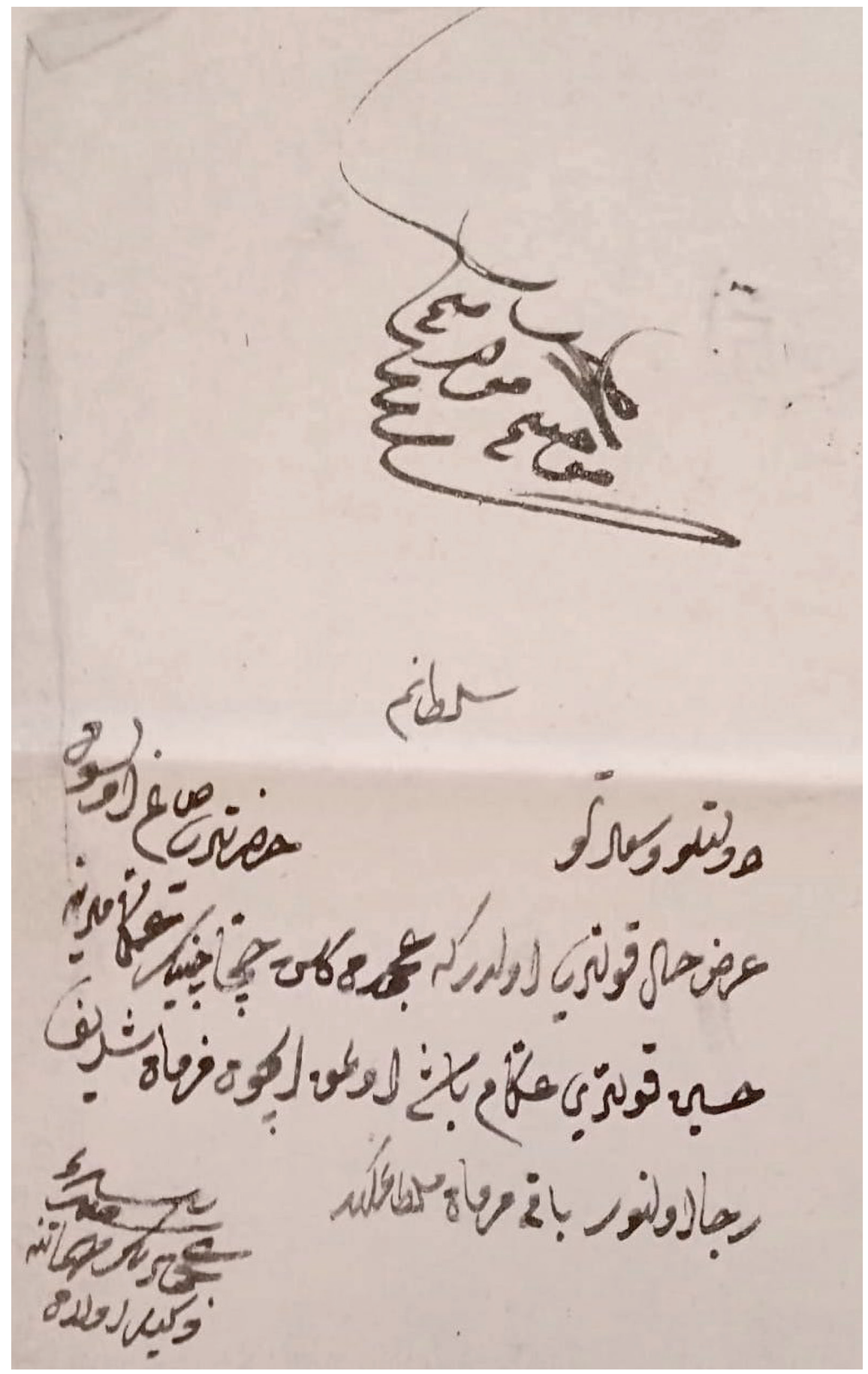

Doc. 14A Bab-ı Asafi-Beylikçi(Divan) Kalemi Belgeleri, 257 / 5-6 


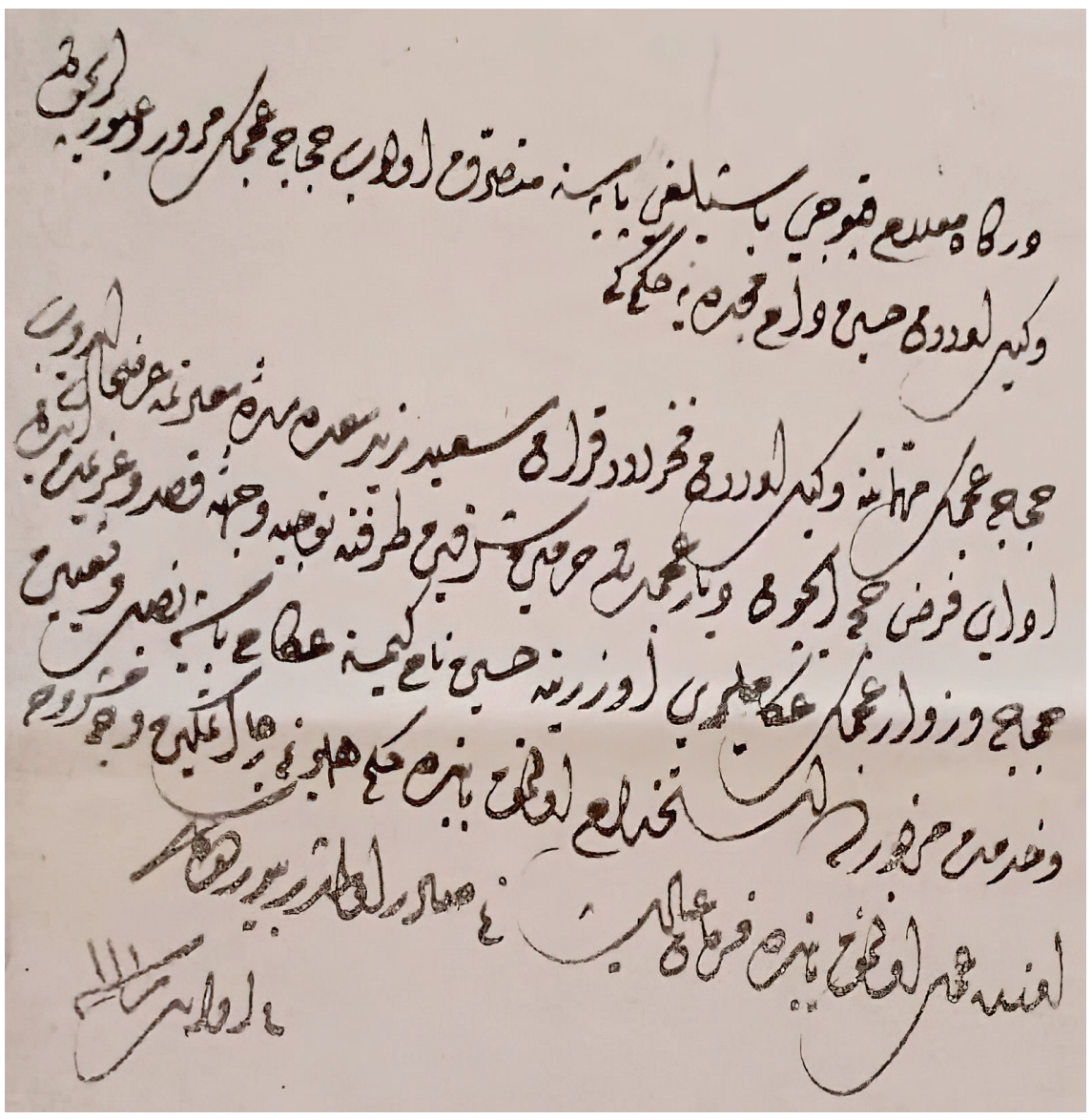

DOC. 14B

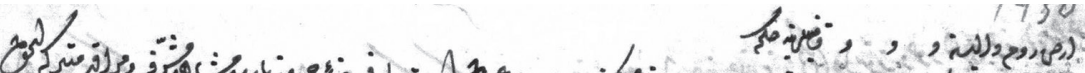

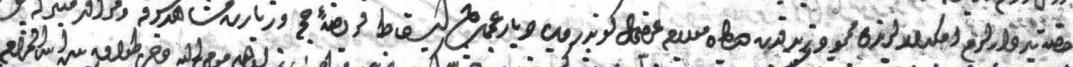
مै

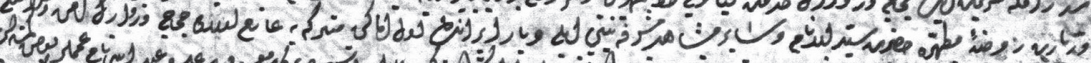
2. 1.

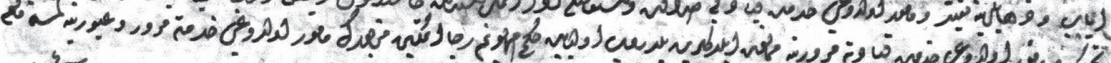
Zuger

Doc. 15 Mühimme Defteri 112, entry 1430 


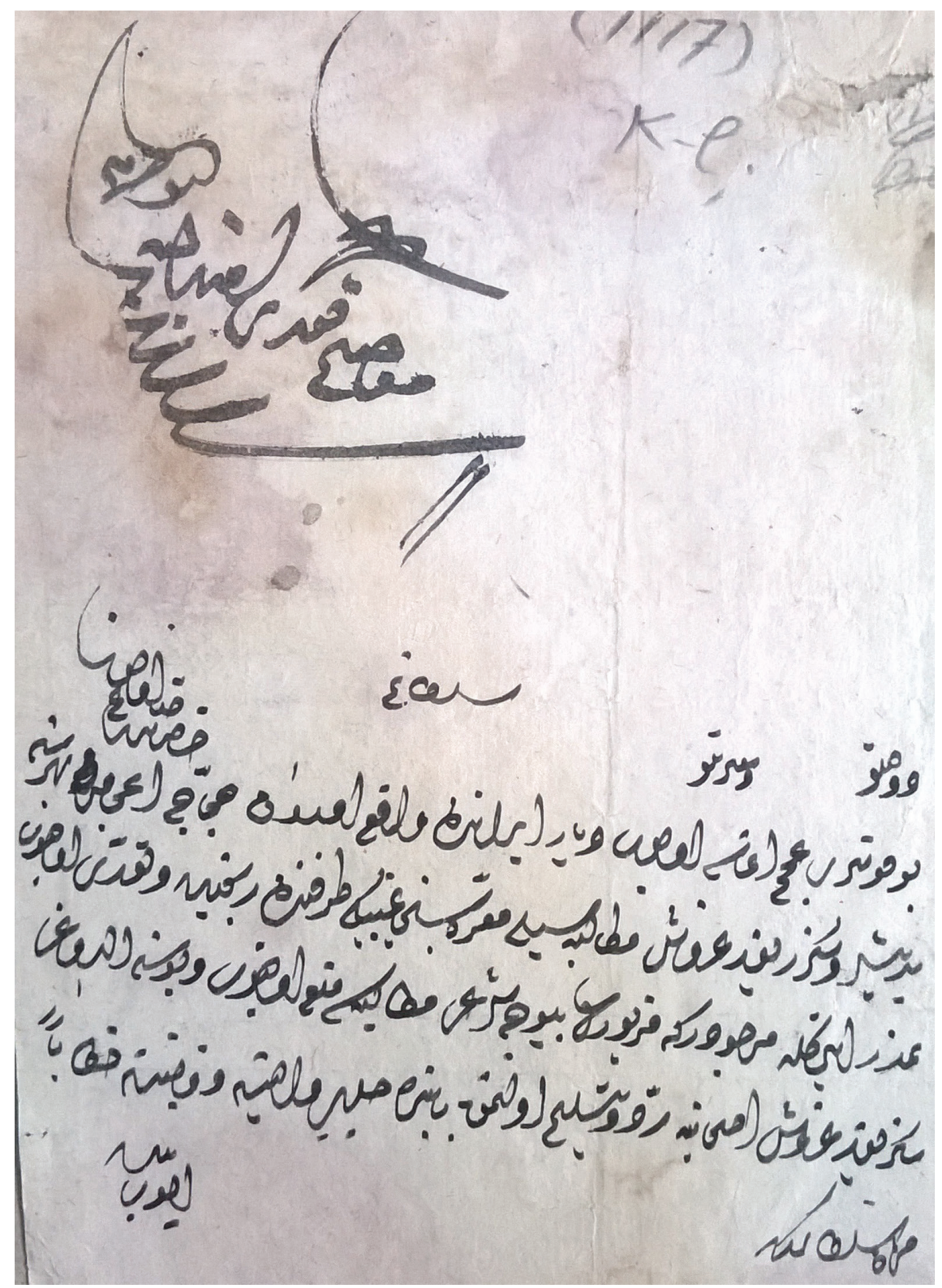

Doc. 16 Bab-ı Asafi—Beylikçi (Divan) Kalemi Belgeleri, 316 / 14 (year 1117) 


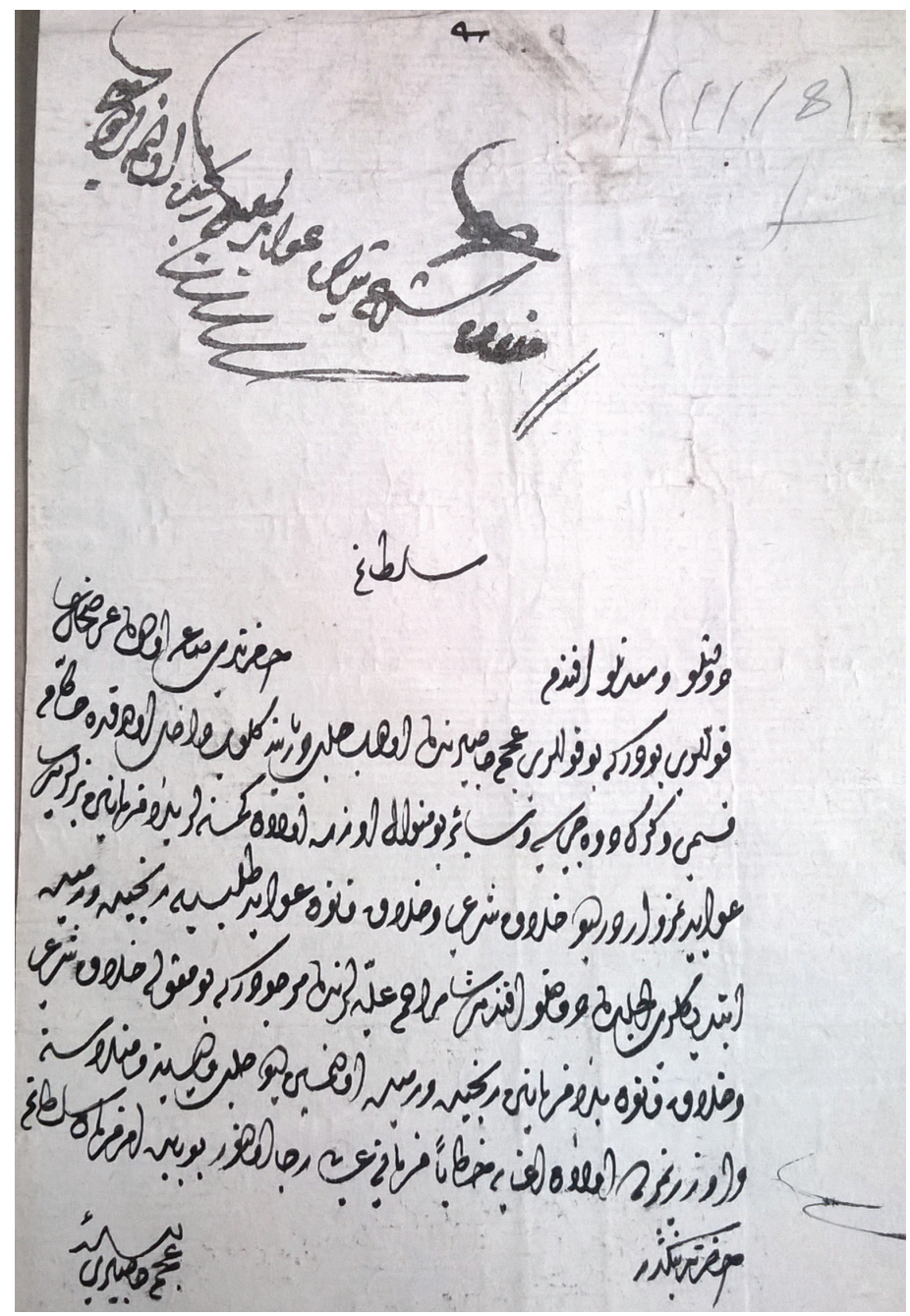

Doc. 17 Bab-ıAsafi-Beylikçi(Divan) Kalemi Belgeleri, 340 / 18 (year 1118)

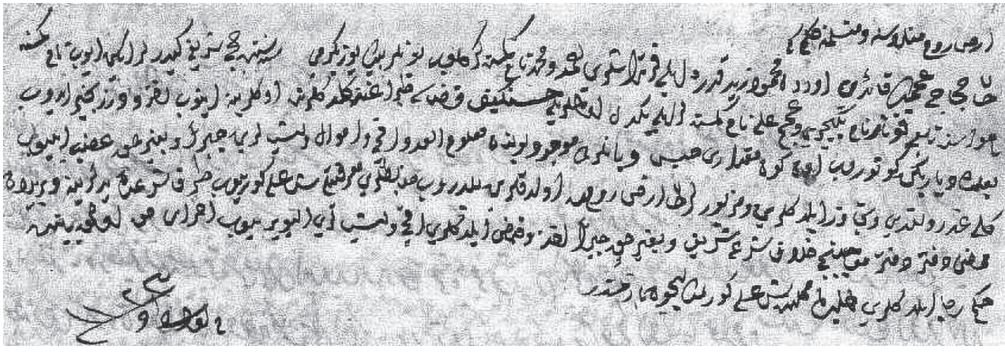

DOC. 18 Mühimme Defteri 118 , entry 1172 


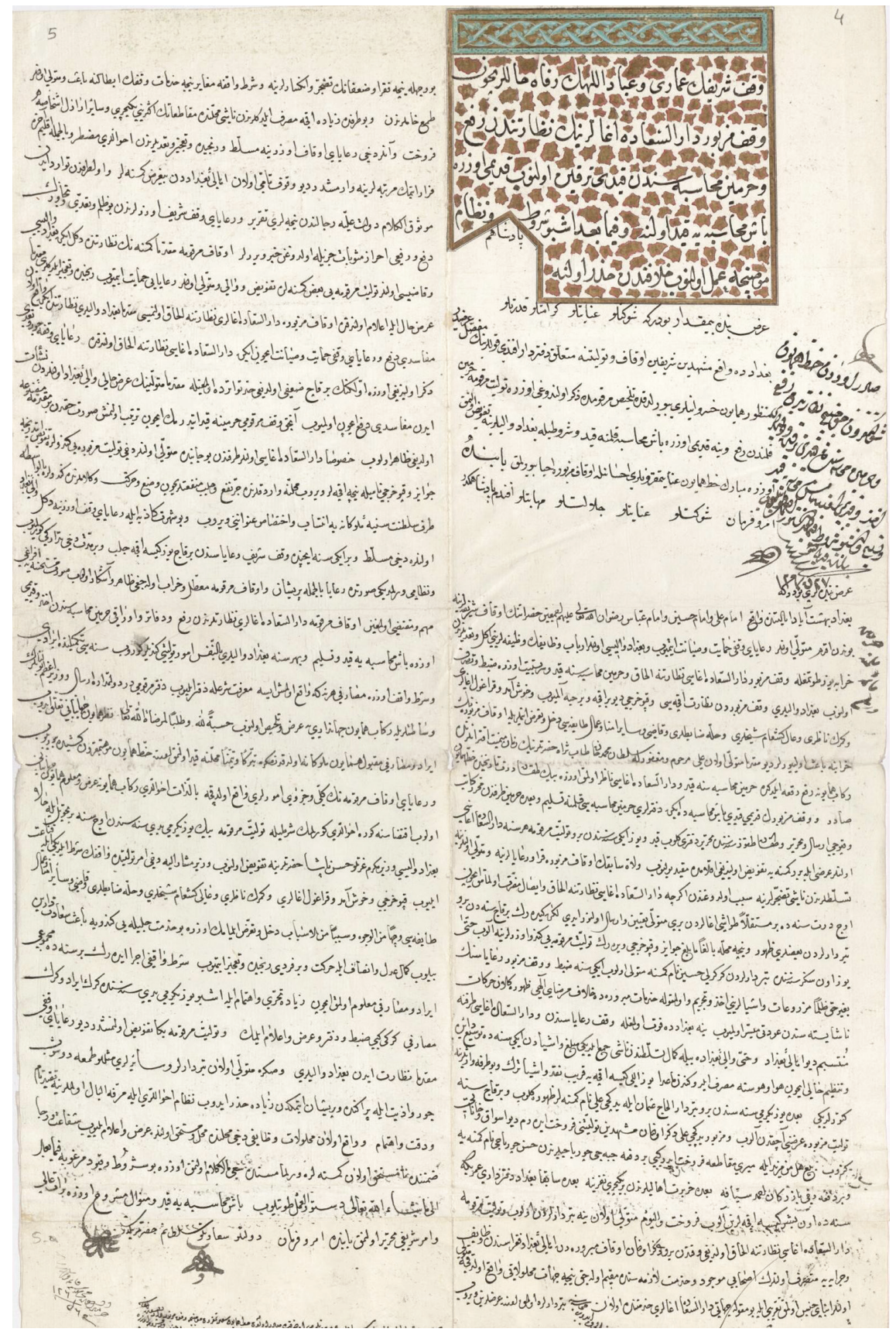

Doc. 19A Evkaf Defteri, 45167 


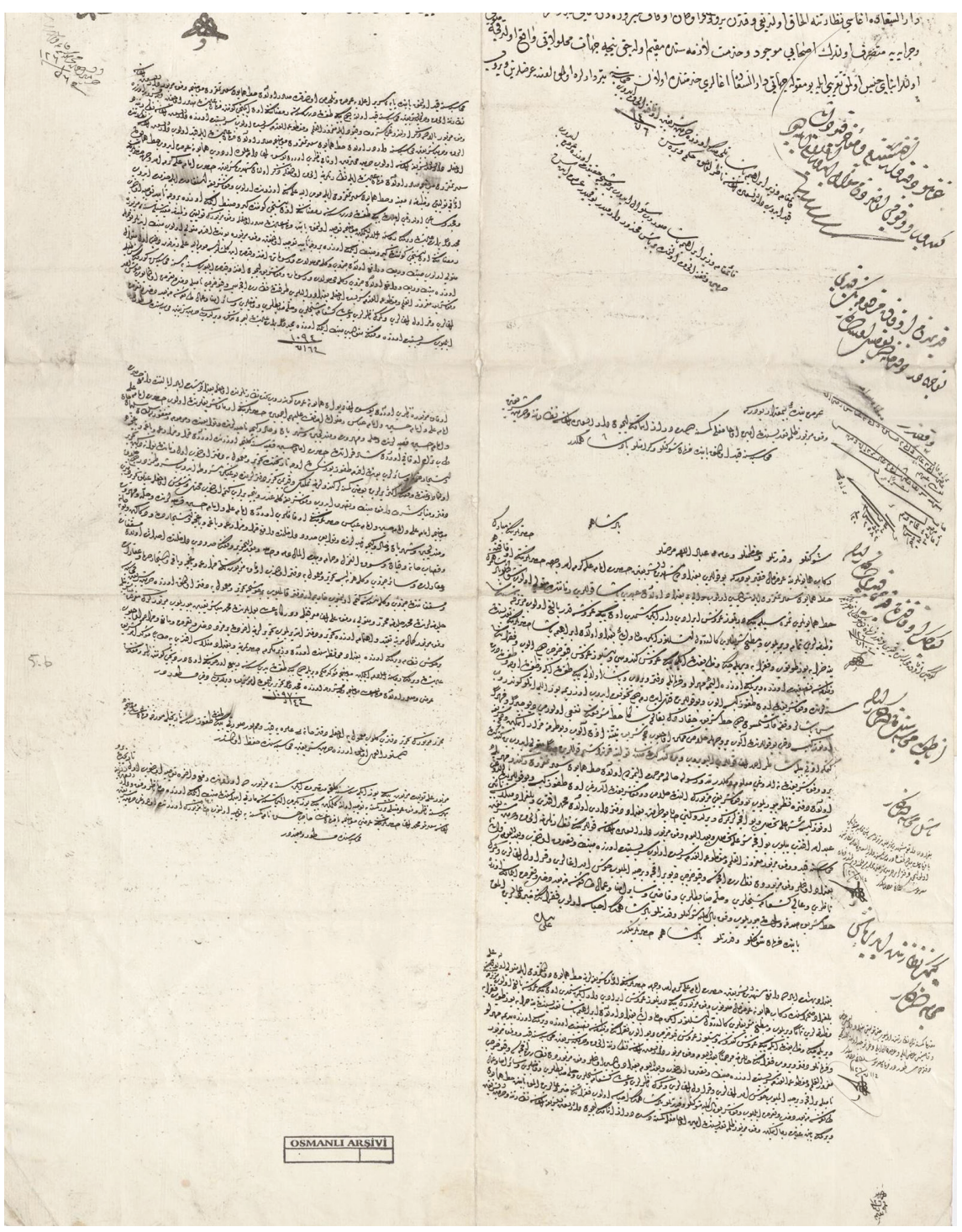

DOC. 19B 


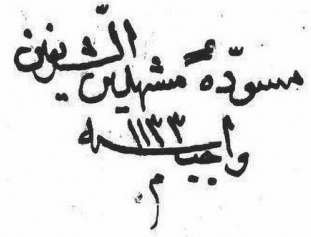

DOC. 20A

Evkaf Haremeyn

Muhasebesi Defteri,

02584 

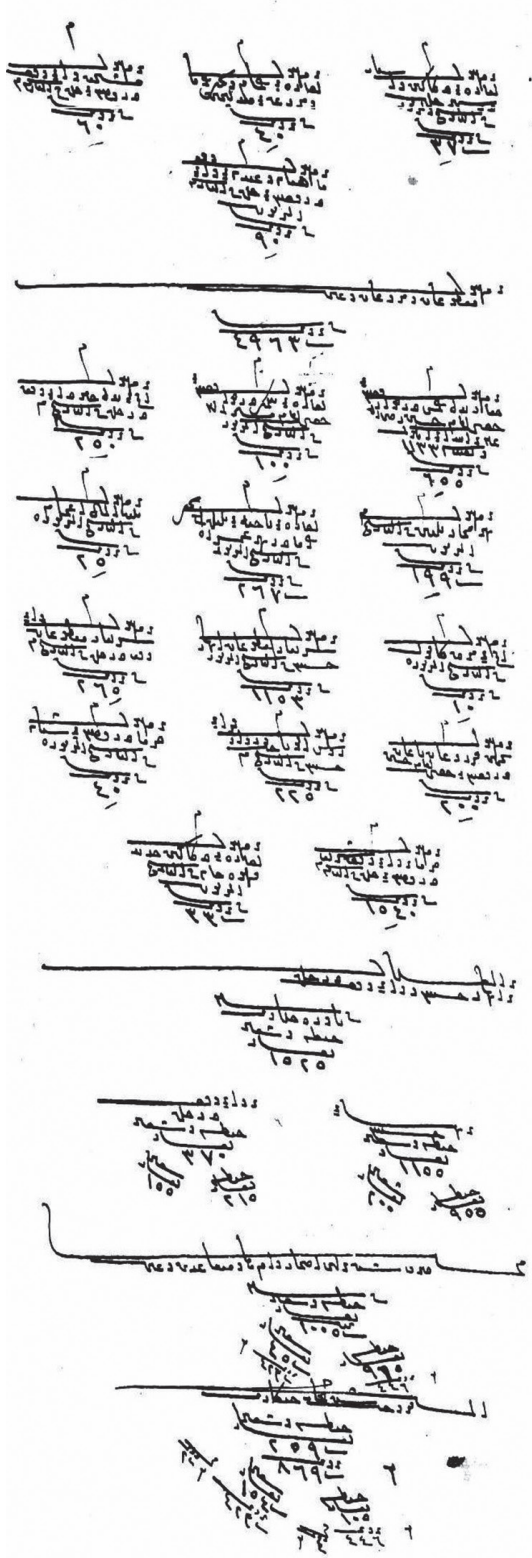
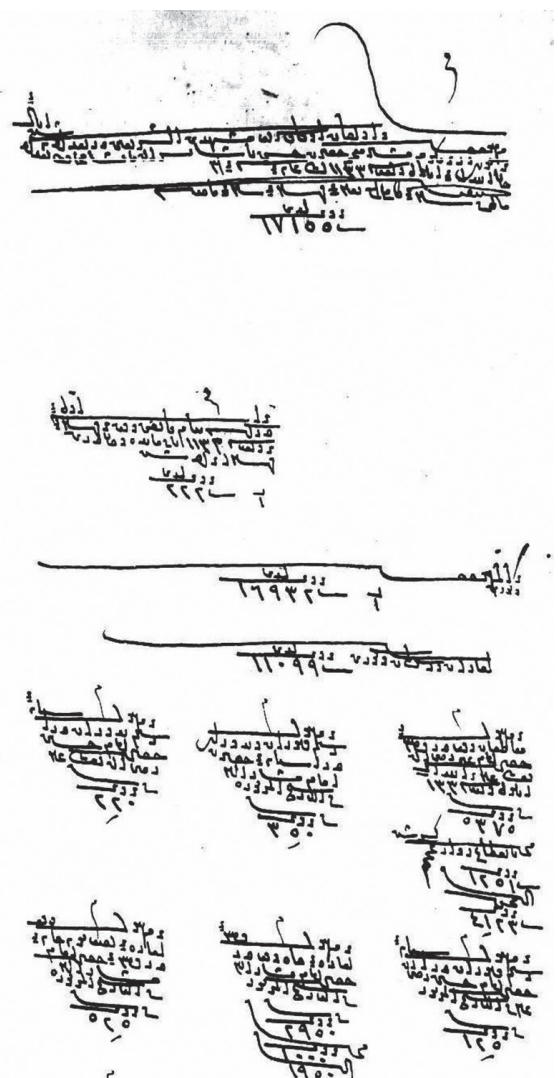
हाराँच
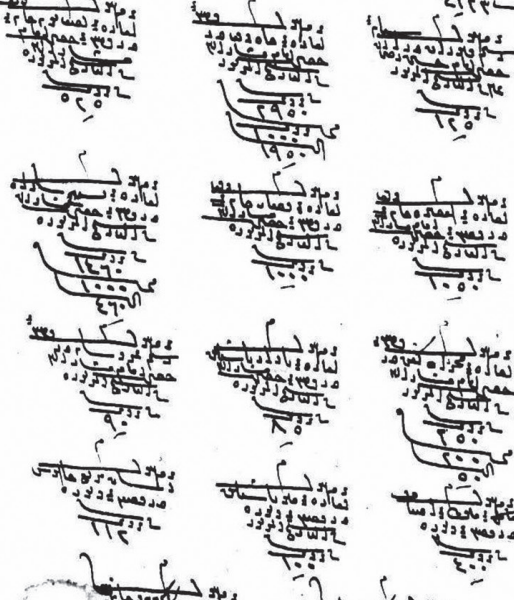

गलगुरा?
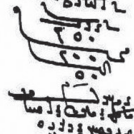

मुगे

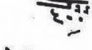

रद: 


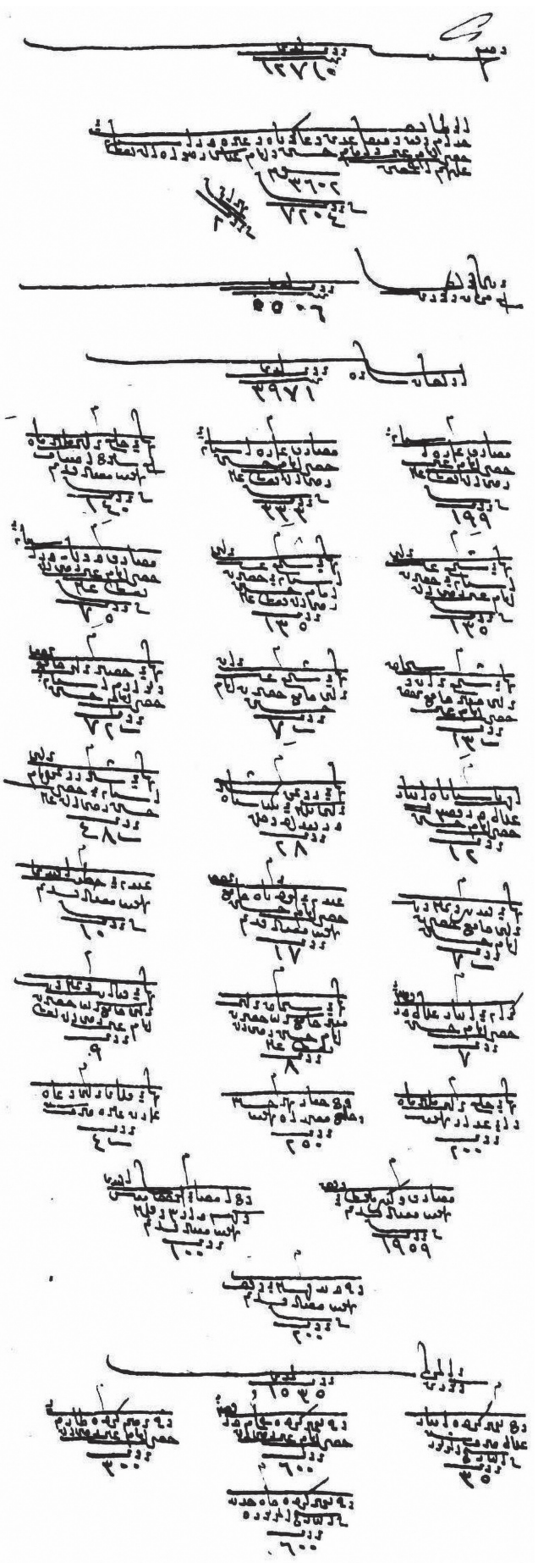

DOC. $20 \mathrm{C}$ 


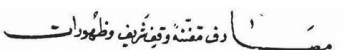

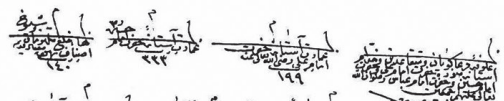

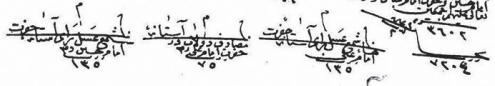

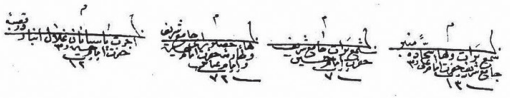

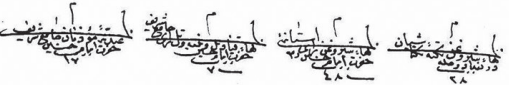

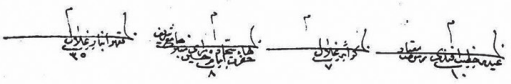

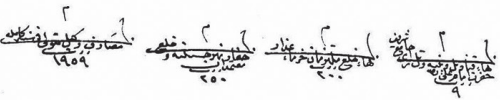

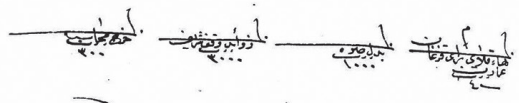

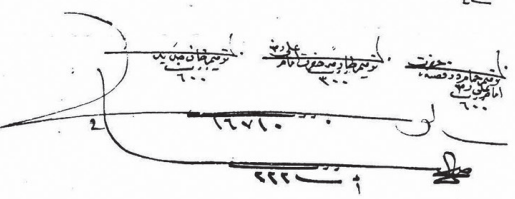

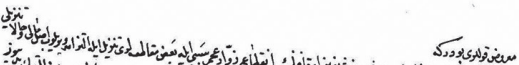

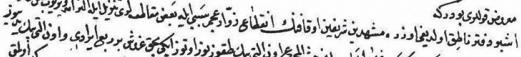

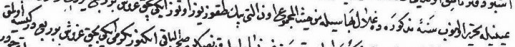

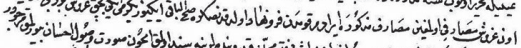

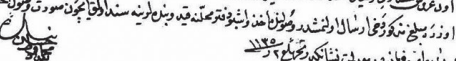

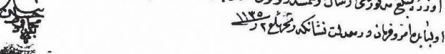

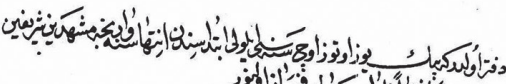

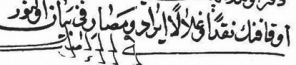

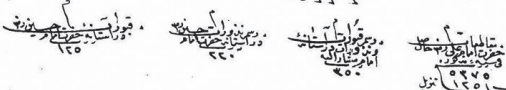
y)

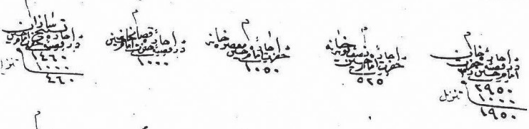

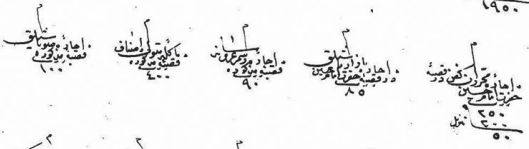

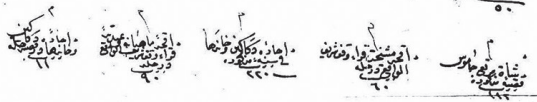

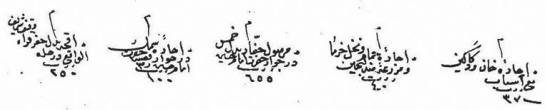

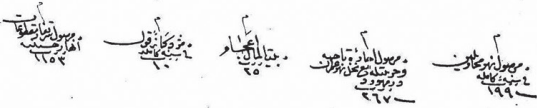

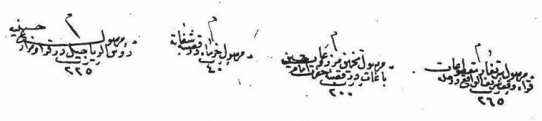

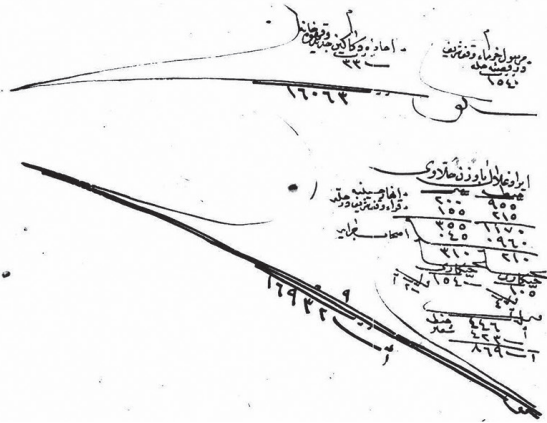

DOC. $20 \mathrm{D}$ 


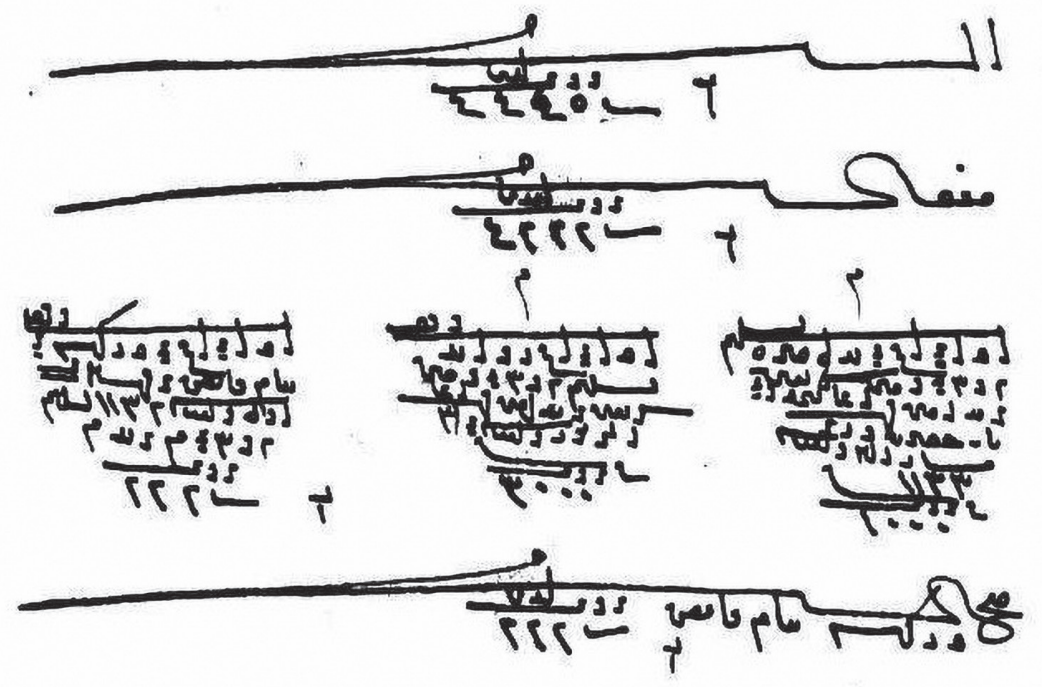

DOC. $20 \mathrm{E}$ 